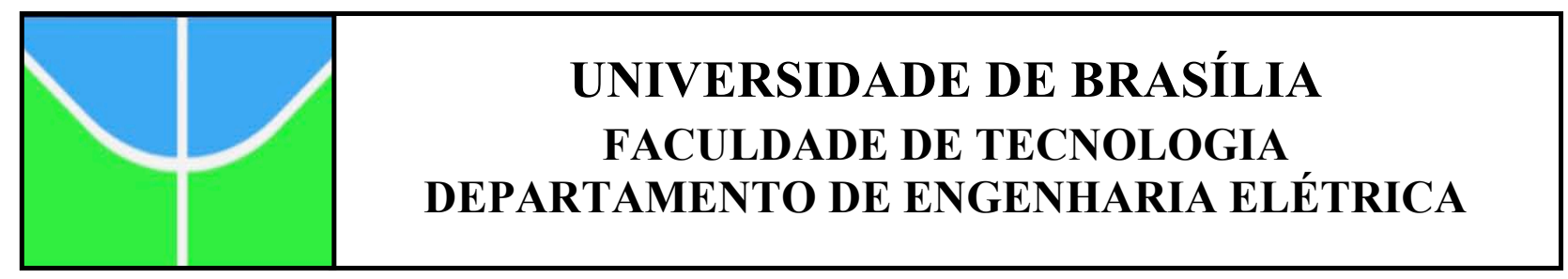

\title{
CARACTERIZAÇÃO DOSIMÉTRICA DE GEL TIPO VIPARnd ATRAVÉS DE TÉCNICAS ÓPTICAS PARA FEIXES DE RAIOS X DE 6MV USADOS EM RADIOTERAPIA EXTERNA
}

\author{
DISSERTAÇÃO DE MESTRADO EM \\ ENGENHARIA DE SISTEMAS ELETRÔNICOS E DE AUTOMAÇÃO
}

Juliana Rosada Dias

Orientadora: Prof ${ }^{a}$. Dra. Artemis Marti Ceschin

Co-orientadora: Prof ${ }^{a}$. Dra. Roseany de Vasconcelos Vieira Lopes 


\section{UNIVERSIDADE DE BRASÍLIA \\ FACULDADE DE TECNOLOGIA \\ DEPARTAMENTO DE ENGENHARIA ELÉTRICA}

CARACTERIZAÇÃO DOSIMÉTRICA DE GEL TIPO VIPARnd ATRAVÉS DE TÉCNICAS ÓPTICAS PARA FEIXES DE RAIOS $X$ DE 6MV USADOS EM RADIOTERAPIA EXTERNA

\section{JULIANA ROSADA DIAS}

DISSERTAÇ̃̃O DE MESTRADO SUBMETIDA AO DEPARTAMENTO DE ENGENHARIA ELÉTRICA DA FACULDADE DE TECNOLOGIA DA UNIVERSIDADE DE BRASÍLIA, COMO PARTE DOS REQUISITOS NECESSÁRIOS PARA A OBTENÇÃO DO GRAU DE MESTRE.

APROVADA POR:
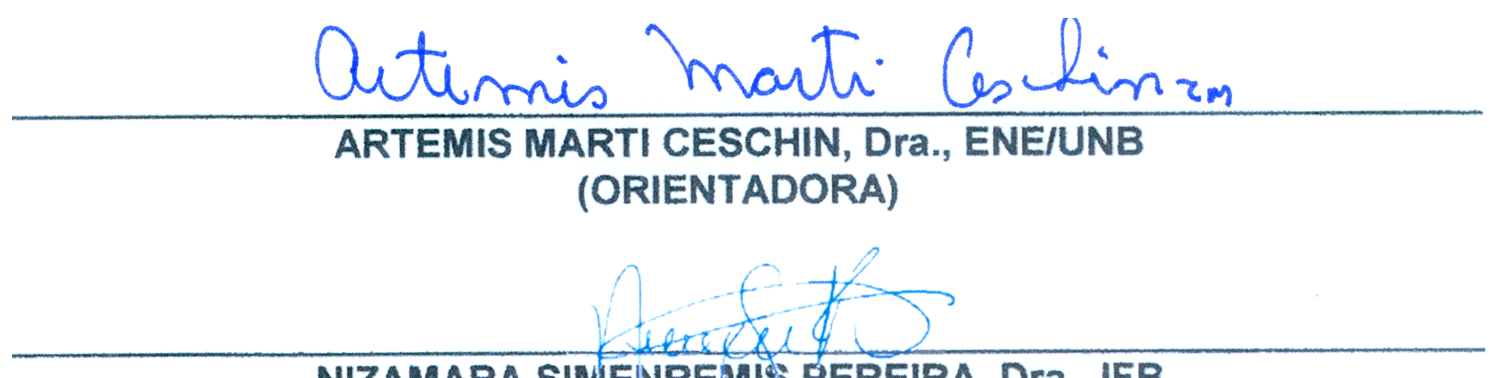

NIZAMARA SINIENREMIS, PEREIRA, Dra., IFB

(EXAMINADORA INTERNA)

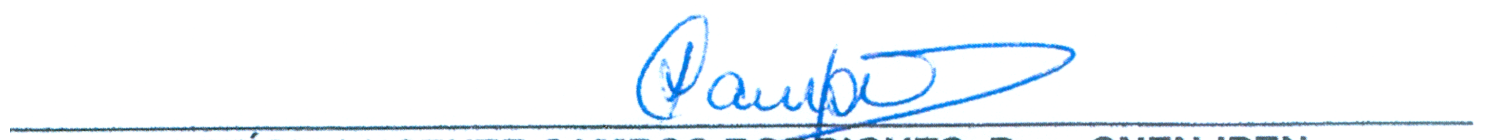

LETICIA LUCENTE CAMPOS RODRIGUES, Dra., CNEN-IPEN

(EXAMINADORA EXTERNA)

Brasília, 23 de junho de 2015. 


\section{DIAS, JULIANA ROSADA}

Caracterização dosimétrica de gel tipo VIPARnd através de técnicas ópticas para feixes de Raios X de 6 MV usados em Radioterapia Externa. [Distrito Federal] 2015.

xv, 68p., $297 \mathrm{~mm}$ (PGEA/FT/UnB, Mestrado, Engenharia de Sistemas Eletrônicos e de Automação, 2015). Dissertação de Mestrado. Universidade de Brasília. Faculdade de Tecnologia.

Departamento de Engenharia Elétrica.
1. Dosimetria gel
2. Gel polimérico
3. Radioterapia
4. Engenharia Biomédica
I. PGEA/FT/UnB
II. Título (série)

\section{REFERÊNCIA BIBLIOGRÁFICA}

DIAS, J. R. (2015). Caracterização dosimétrica de gel tipo VIPARnd através de técnicas ópticas para feixes de Raios X de 6 MV usados em Radioterapia Externa. Dissertação de Mestrado em Engenharia de Sistemas Eletrônicos e de Automação, Publicação PGEA DM-595/2015, Departamento de Engenharia Elétrica, Universidade de Brasília, Brasília, DF, 68p.

\section{CESSÃO DE DIREITOS}

AUTOR: Juliana Rosada Dias

TÍTULO: Caracterização dosimétrica de gel tipo VIPARnd através de técnicas ópticas para feixes de Raios X de 6 MV usados em Radioterapia Externa.

GRAU: Mestre

ANO: 2015

É concedida à Universidade de Brasília permissão para reproduzir cópias desta dissertação de mestrado e para emprestar ou vender tais cópias somente para propósitos acadêmicos e científicos. $\mathrm{O}$ autor reserva outros direitos de publicação e nenhuma parte dessa dissertação de mestrado pode ser reproduzida sem autorização por escrito do autor.

Juliana Rosada Dias 
"O começo de todas as ciências é o espanto de as coisas serem o que são."

(Aristóteles) 
Dedico este trabalho a todas as pessoas que eu amo. 


\section{AGRADECIMENTOS}

Agradeço a Deus por mais essa conquista.

Aos meus pais, Valter e Maria Inês, por estarem sempre presentes, por acreditarem em mim, pelo amor, paciência, cuidados e incentivo.

Ao meu esposo Thyago Fressatti Mangueira, companheiro e amigo, meu maior incentivador, por seu amor, apoio e compreensão. Agradeço também pela parceria durante todas as etapas deste trabalho e pela grande colaboração cientifica sobre a dosimetria gel.

À toda a minha família pela compreensão e apoio, em especial aos meus tios Antônio Sérgio e Ana e aos meus primos Bruno, Elizabete, Júlio e Flávio.

Aos meus queridos amigos que estiveram presentes, em especial à Gisele, Simone e Adriana pela grande amizade e apoio.

Aos colegas de trabalho pela compreensão, em especial a Beatriz pelo incentivo e ombro amigo nas horas árduas.

À minha orientadora, Artemis Marti Ceschin pela paciência, pela confiança, credibilidade, dedicação e trabalho ao longo do meu mestrado.

À minha co-orientadora, Roseany de Vasconcelos Vieira Lopes, pelos ensinamentos, paciência, amizade, e pela ajuda no desenvolvimento deste trabalho.

Ao Departamento de Engenharia Elétrica da Universidade de Brasília pela oportunidade de executar este trabalho.

Ao Conselho Nacional do Desenvolvimento Científico e Tecnológico (CNPq) pelo auxílio financeiro ao trabalho de pesquisa.

Ao Instituto de Radioterapia de Taguatinga pelos equipamentos disponibilizados para irradiação do gel.

À Dra. Maria José Araújo Sales, do Laboratório de Polímeros (LabPol) do Instituto de Química da Universidade de Brasília, pelas contribuições no desenvolvimento deste trabalho, interesse, colaboração e disponibilização do laboratório para confecção do gel.

Ao DSc. Marek Kozicki pelas discussões e ajuda sobre a preparação do gel.

À Renata S. Lima, do Laboratório de Polímeros (LabPol) do Instituto de Química da Universidade de Brasília, pelas contribuições na confecção do gel.

Aos professores e colegas do Laboratório de Dispositivos e Circuitos Integrados (LDCI), pelas contribuições e pelo ótimo ambiente de trabalho.

A gratidão é uma das maneiras de manifestar o carinho e respeito às pessoas que colaboram para nosso crescimento e, também, de reconhecer que é impossível vencer sozinho. 


\section{RESUMO}

Neste trabalho as principais características ópticas do dosímetro gel VIPARnd foram avaliadas para feixes de fótons de $6 \mathrm{MV}$ usados em radioterapia externa. $\mathrm{O}$ espectro de absorvância do dosímetro gel foi avaliado com espectrofotometria óptica e através do processamento de imagens fotográficas adquiridas com câmera de sensor CMOS para doses de 0 a 50 Gy. Foram avaliadas duas soluções com concentrações diferentes dos componentes do gel. Os dados obtidos através da espectrofotometria óptica mostram que o VIPARnd apresenta pico de absorção entre 300 a $320 \mathrm{~nm}$ dependendo da dose absorvida. O aumento da dose absorvida causa aumento na absorvância do VIPARnd. As curvas de dose resposta foram analisadas em função do máximo de absorção e também através da área sob o espectro. A solução 1 apresenta região linear de 3 a 20 Gy e a solução 2 para a região de 0,5 a 5 Gy. A repetitividade entre amostras de um mesmo lote ficou em $0,5 \%$ e a reprodutibilidade inter-lotes em $5 \%$. A estabilidade do gel VIPARnd foi mantida para um tempo pós-irradiação de pelo menos 15 dias. As imagens fotográficas foram adquiridas em escala RGB, a partir da análise de absorção óptica foi suposto que a componente azul apresentasse maior resposta para determinação da dose absorvida o que de fato foi comprovado com os dados obtidos. Para este caso a faixa de resposta linear obtida foi entre 3 e 20 Gy para a solução 1 e entre 0,5 e 20 Gy para a solução 2. Como testes adicionais, foi analisado a curva de dose resposta a partir de imagens de tomografia computadorizada, assim como o estudado da aplicação do gel para medidas de perfil de campos pequenos e PDP para feixes de raios X de $6 \mathrm{MV}$ e a resposta do gel à irradiações com fonte de irídio 192 usadas em braquiterapia de alta taxa de dose. O bom desempenho do dosímetro VIPARnd nos testes realizados indica que este pode ser utilizado na avaliação tridimensional da dose em tratamento radioterápicos. 


\begin{abstract}
This work aims to evaluate the optical characteristics of a dosimeter VIPARnd for $6 \mathrm{MV}$ photon beam used in radiotherapy. The absorbance spectrum of irradiated gel dosimeter was evaluated with optical spectrophotometer techniques and with CMOS camera readout for dose range of 0 to $50 \mathrm{~Gy}$. Two solutions with different concentration were evaluated. Data shows that the VIPARnd has a maximum absorbance at 300 to $320 \mathrm{~nm}$ depending on the absorbed dose. The absorbed dose increases the absorbance values of VIPARnd. The dose response curves were obtained by the peak value and the relative area under of absorbance curve. The solution 1 shown interval of linearity from 3 to $20 \mathrm{~Gy}$ and the solution 2 from 0,5 to $5 \mathrm{~Gy}$. The repeatability and inter-batch reproducibility of gel response were $0,5 \%$ and $5 \%$ respectively. Temporal analysis indicates that the gel dosimeter has no significant variation in absorbance peak for the post irradiation times until 15 days. The CMOS camera readouts were obtained in RGB color, the absorbance measurements suggest a major response of dose for blue matrix verified with data. The dose response curve for blue component showed interval of linearity from 3 to $20 \mathrm{~Gy}$ for solution 1 and from 0,5 to $20 \mathrm{~Gy}$. Additional tests were performed to determine the dose response with X-ray computed tomography, analyses of dose profile measurements for small field radiation therapy and percentage depth dose for $6 \mathrm{MV}$ photon beam and gel response for irradiation with Iridium 192 source in high dose rate brachytherapy. These characteristics indicate that the presented VIPARnd polymer gel could be helpful for radiotherapy dosimetry.
\end{abstract}




\section{SUMÁRIO}

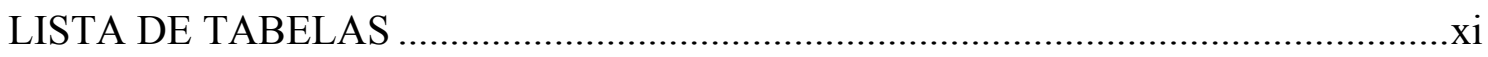

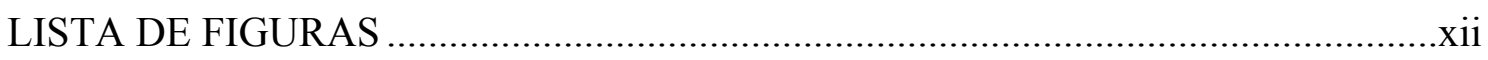

LISTA DE ABREVIATURAS, SIGLAS E SÍMBOLOS............................................

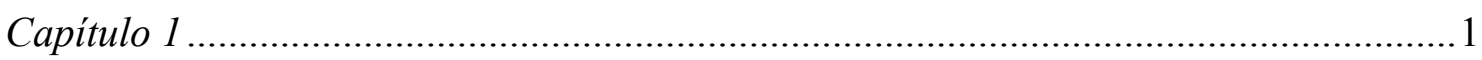

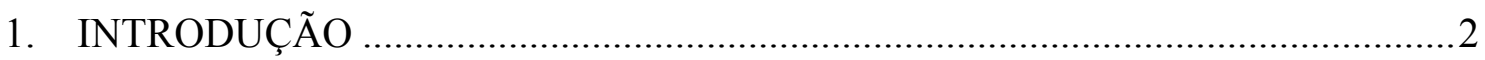

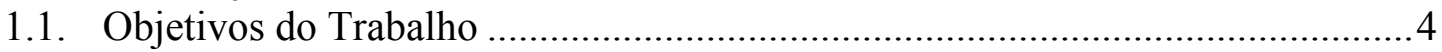

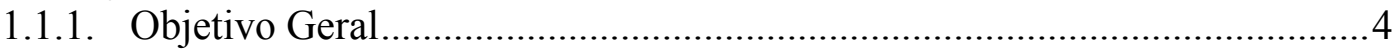

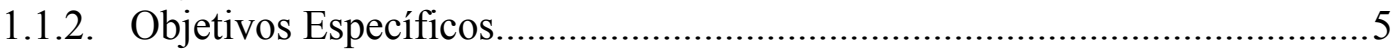

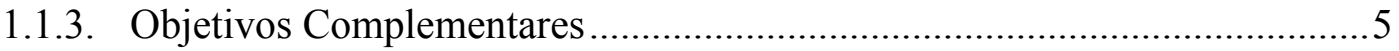

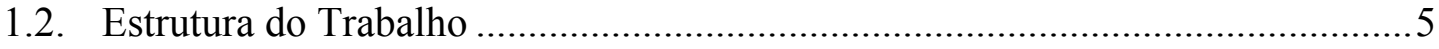

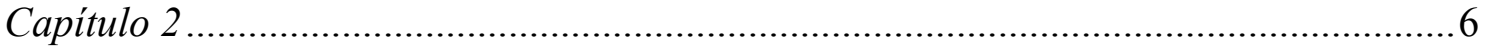

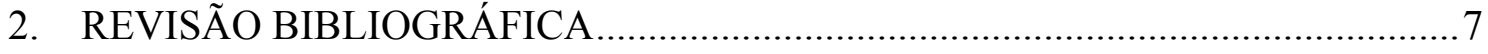

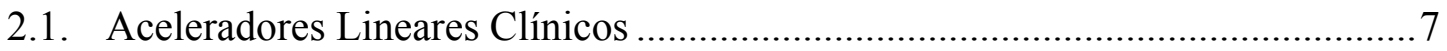

2.2. Grandezas e parâmetros dosimétricos ............................................................... 9

2.3. Código de práticas para dosimetria de fótons e elétrons de alta energia ............12

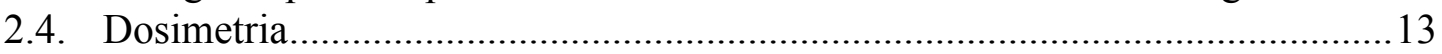

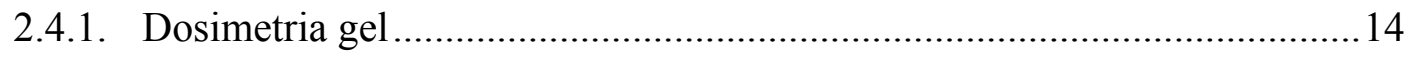

2.5. Dosímetros gel baseados em N-vinilpirrolidona (NPV) .................................. 16

2.5.1. Características químicas dos componentes do dosímetro gel tipo

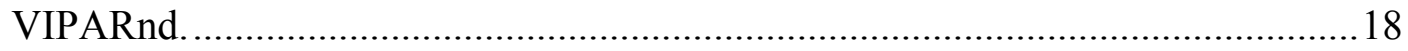

2.5.2. Reações químicas no gel dosímetro tipo VIPARnd..................................... 19

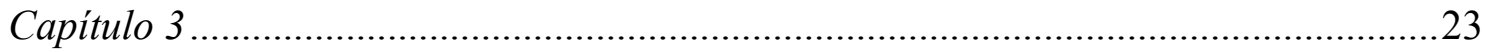

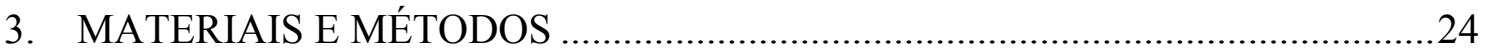

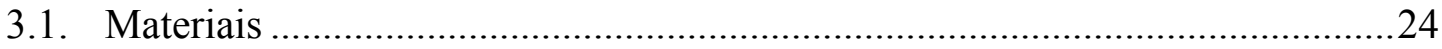

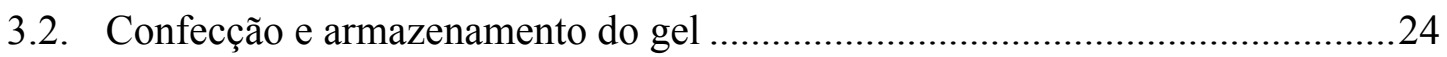

3.3. Objeto simulador para medidas com as cubetas .............................................26

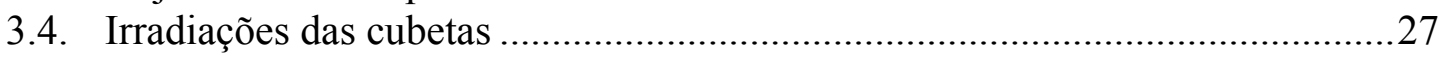

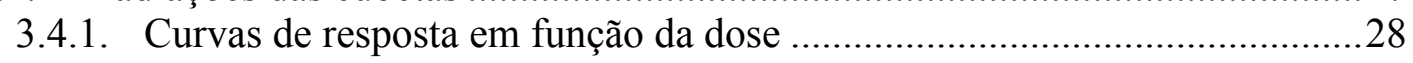

3.4.2. Repetitividade e Reprodutibilidade........................................................28

3.4.3. Dependência da resposta com a taxa de dose .........................................29

3.4.4. Variação da absorvância em função do tempo de leitura pós irradiação ....29

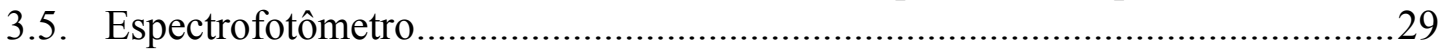

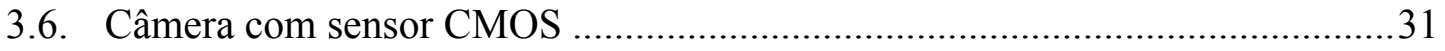

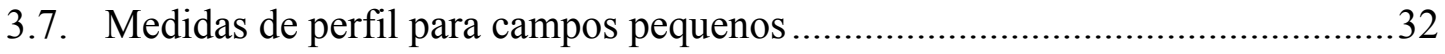

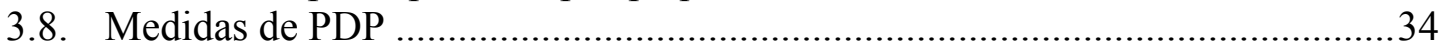

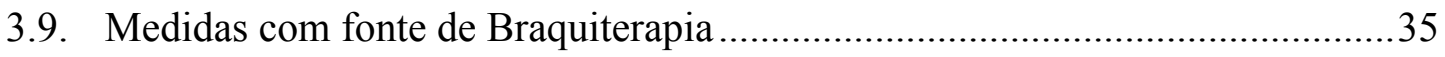

3.10. Medidas com Tomografia Computadorizada................................................... 36 


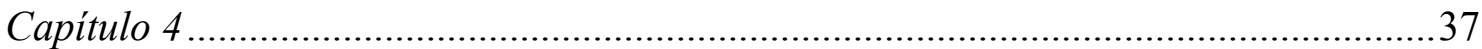

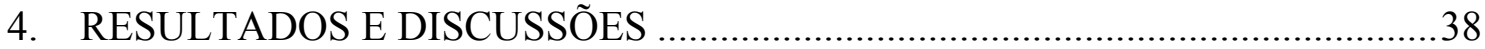

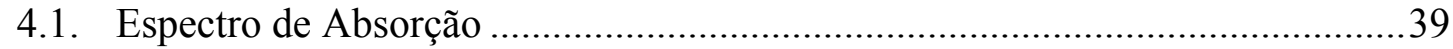

4.2. Dose resposta em função do máximo de absorção ...........................................42

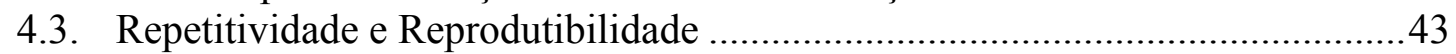

4.4. Dependência da resposta com a taxa de dose ...................................................46

4.5. Variação da absorvância em função do tempo de leitura pós irradiação............47

4.6. Dose resposta em função da área sobre a curva de absorção..............................48

4.7. Dose resposta em função das imagens com câmera de sensor CMOS ...............50

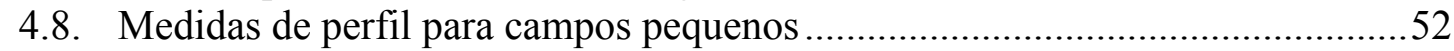

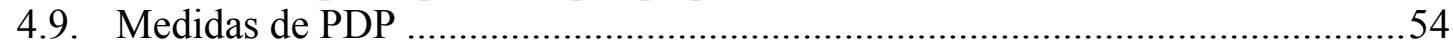

4.10. Medidas com fonte de Braquiterapia .............................................................5

4.11. Medidas com Tomografia Computadorizada..................................................57

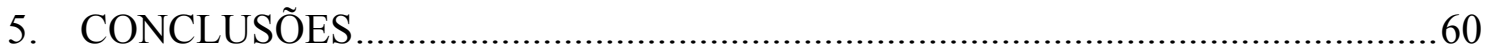

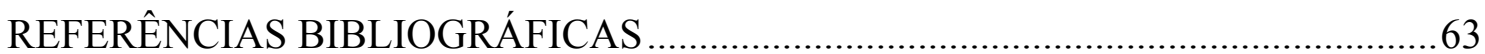




\section{LISTA DE TABELAS}

Tabela 1 - Composição das duas concentrações de gel estudadas. 24

Tabela 2 - Coeficientes do ajuste linear da curva dose resposta em função do máximo de absorvância.

Tabela 3 - Coeficientes do ajuste linear da curva dose resposta em função da área da curva de absorvância.

Tabela 4 - Coeficientes do ajuste linear da curva dose resposta em função das componentes Azul e Verde das imagens com câmera com sensor CMOS

Tabela 5 - Porcentagem de pontos falhos na análise Gamma $3 \%, 3 \mathrm{~mm}$. 


\section{LISTA DE FIGURAS}

Figura 1 - Esquema de um Acelerador Linear para Radioterapia.

Figura 2 - Esquema do cabeçote de um Acelerador Linear para Radioterapia.

(a) Esquema para produção de Raios X, (b) esquema para a utilização do feixe de elétrons.

Figura 3 - Gráfico da dose absorvida em função da profundidade, indicando

as regiões de build up, EPC e ETPC.

Figura 4 - Estruturas químicas do NPV (esquerda) e do BIS (direita).

Figura 5 - Esquema de formação do radical peróxido através da interação do oxigênio com uma parte da cadeia polimérica.

Figura 6 - Radicais formados a partir da interação do NVP com os radicais livres

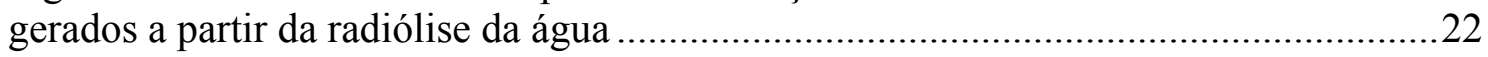

Figura 7 - Montagem experimental para confecção do gel. .........................................25

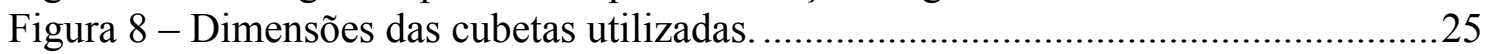

Figura 9 - Efeito de uma bolha de ar no gel VIPARnd após a irradiação. ......................26

Figura 10 - Objeto simulador usado para irradiação das cubetas. ................................26

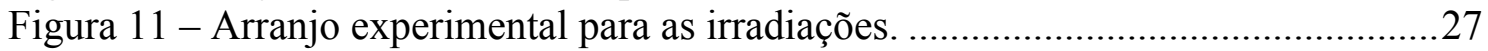

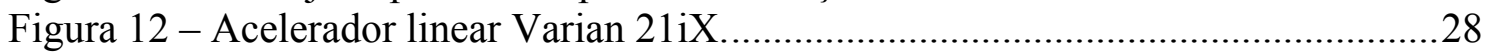

Figura 13 - Espectrofotômetro Thermo Scientific............................................................. 30

Figura 14 - Arranjo experimental do sistema de leitura com câmera.............................. 31

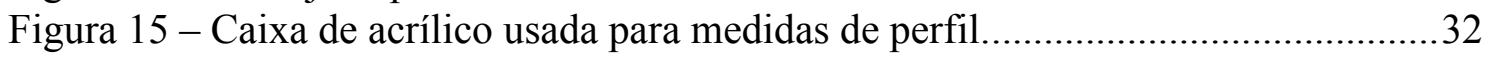

Figura 16 - Arranjo experimental para medidas de perfil. ........................................... 32

Figura 17 - Arranjo experimental para medida de PDP. ............................................. 34

Figura 18 - Frasco de vidro usado para as medidas com a fonte de braquiterapia..........35

Figura 19 - Distribuição de dose prevista para o plano de braquiterapia. ........................36

Figura 20 - Alteração de cor no dosímetro VIPARnd com as concentrações da

solução 1 devido a irradiação com raios X de $6 \mathrm{MV}$. (a) Gel com as concentrações da solução 1 , da esquerda para direita doses de $0,3,5,10,15$, 20 e $50 \mathrm{~Gy}$. (b) Gel com as concentrações da solução 2, da esquerda para direita doses de $0,0,5,1,2,3,4,5,10,15,20$ e 50 Gy.

Figura 21 - Espectro de absorvância na região visível e ultra violeta para o gel

VIPARnd. (a) Solução 1 com doses de 0 Gy e 10 Gy, (b) Solução 2 com doses

de 0 Gy e 3 Gy.

Figura 22 - Espectro de absorvância para o intervalo de 280 a $480 \mathrm{~nm}$ para a

solução 1 de gel VIPARnd para as doses de 0 Gy, 1 Gy, 3 Gy, 5 Gy, 10 Gy,

15 Gy, 20 Gy e 50 Gy.

Figura 23 - Espectro de absorvância para o intervalo de 280 a $480 \mathrm{~nm}$ para a

solução 2 de gel VIPARnd para as doses de 0 Gy, 1 Gy, 3 Gy, 5 Gy, 10 Gy,

15 Gy, 20 Gy e 50 Gy.

Figura 24 - Espectro de absorvância para o intervalo de 280 a $480 \mathrm{~nm}$ para a

solução 2 de gel VIPARnd para as doses de 0 Gy, 1 Gy, 2 Gy, 3 Gy, 4 Gy e 5 Gy.......41

Figura 25 - Curva de dose resposta em função do máximo de absorção para a

solução 1 de VIPARnd.

Figura 26 - Curva de dose resposta em função do máximo de absorção para a

solução 2 de VIPARnd.

Figura 27 - Absorvância Relativa (valor absoluto dividido pelo valor médio)

para cubetas irradiadas de um mesmo lote da solução 1

Figura 28 - Absorvância Relativa (valor absoluto dividido pelo valor médio)

para cubetas de um mesmo lote da solução 2 . 
Figura 29 - Absorvância Relativa (valor absoluto dividido pelo valor médio) para 20 lotes da solução 1 .....

Figura 30 - Absorvância Relativa (valor absoluto dividido pelo valor médio) para 20 lotes da solução 2

Figura 31 - Absorvância Relativa (valor absoluto dividido pelo valor médio) em função da taxa de dose para a solução 1

Figura 32 - Absorvância Relativa (valor absoluto dividido pelo valor médio)

em função da taxa de dose para a solução 2 .

Figura 33 - Valores de absorvância máxima para diferentes tempos após a irradiação para a solução 1 .

Figura 34 - Valores de absorvância máxima para diferentes tempos após a irradiação para a solução 2 .

Figura 35 - Curva de dose resposta em função da área sob a curva de absorção para a solução 1 de VIPARnd.

Figura 36 - Curva de dose resposta em função da área sob a curva de absorção para a solução 2 de VIPARnd.

Figura 37 - Curva de densidade óptica em função da dose para cada componente da matriz RGB da solução 1 .

Figura 38 - Curva de densidade óptica em função da dose para cada componente da matriz RGB da solução 2

Figura 39 - Imagem usada para medida dos perfis do campo quadrado de

$5 \mathrm{~cm} \times 5 \mathrm{~cm}$ (esquerda) e dos circulares com cones (direita).

Figura 40 - Comparação entre as medidas de perfil obtidas com gel VIPARnd e os dados do sistema de planejamento (SP). (a) Campo $5 \mathrm{~cm}$ x $5 \mathrm{~cm}$, (b) cone de $30 \mathrm{~mm}$, (c) cone de $20 \mathrm{~mm}$, (d) cone de $15 \mathrm{~mm}$, (e) cone de $10 \mathrm{~mm}$, (f) cone de 7,5 mm.........53

Figura 41 - Tubo de ensaio usado para medida de PDP após a irradiação......................54

Figura 42 - Comparação entre a medida de PDP para um campo de $10 \mathrm{~cm} \times 10 \mathrm{~cm}$ obtida com gel VIPARnd e os dados do sistema de planejamento................................55

Figura 43 - Imagem do frasco de vidro após irradiação com fonte de irídio 192 ..........56

Figura 44 - Comparação entre a distribuição de dose medida com VIPARnd para

o plano de braquiterapia e a distribuição prevista pelo sistema de planejamento............56

Figura 45 - Imagem axial obtida a partir da tomografia computadorizada de um lote de cubetas.

Figura 46 - Curva dose resposta em função do número TC para a solução 2

de VIPARnd. 


\section{LISTA DE ABREVIATURAS, SIGLAS E SÍMBOLOS}

2D - Bidimensional

3D - Tridimensional

ASC - Ácido ascórbico

BIS - N'metilenobisacrilamida

CCD - Charge-coupled device

CMOS - Complementary metal-oxide semiconductor

D - Dose absorvida

D.O. - Densidade óptica

EPC - Equilíbrio de partículas carregadas

ETPC - Equilíbrio transiente de partículas carregadas

Gy - Gray

IAEA - International Atomic Energy Agency

ICRU - Comission on Radiation Units and Measurements

IMAT - Radioterapia em Arco de Intensidade Modulada

IMRT - Radioterapia de Intensidade Modulada

INCA - Instituto Nacional do Câncer

IRM - Imagens por ressonância magnética nuclear

$\mathrm{MeV}$ - mega elétron volt

MLC - Multileaf collimator

$\mathrm{MV}$ - mega volts

NVP - N-vinilpirrolidona

PDP - Curva de porcentagem de dose em profundidade

$\mathrm{PDP}_{20,10}$ - Razão entre a dose na profundidade de $20 \mathrm{~cm}$ pela dose na profundidade de $10 \mathrm{~cm}$

PQRT - Programa de Qualidade em Radioterapia

R1 - Taxa de relaxação spin-rede

R2 - Taxa de relaxação spin-spin

$\mathrm{R}_{50}$ - Profundidade na qual se tem uma leitura de carga correspondente a $50 \%$ do valor máximo para medidas com elétrons

$\mathrm{R}_{50 \text {,ín }}-50 \%$ do valor máximo de ionização para medidas com elétrons

$\mathrm{RF}$ - Radiofreqüência 
RGB - sistema de cores aditivas formado por Vermelho (Red), Verde (Green) e Azul (Blue))

RMN - Ressonância Magnética Nuclear

SRS - Radiocirurgia Estereotáxica (Stereotaxic Radiosurgey)

SP - Sistema de planejamento

$\mathrm{T} 1$ - tempo de relaxamento longitudinal do próton de hidrogênio

$\mathrm{T} 2$ - tempo de relaxamento transversal do próton de hidrogênio

TC - Tomografia computadorizada por raios X

TCO - Tomografia de coerência óptica

TE- Tempo de eco

THPC - Tetrahidroxifenilclorina

$\mathrm{TPR}_{20,10}$ - Razão da relação tecido meio (TPR- tissue phantom ratio) na profundidade de $20 \mathrm{~cm}$ com o TPR na profundidade de $10 \mathrm{~cm}$

$\mathrm{UM}$ - unidade monitora

VIPAR - N-vinylpyrrolidone argon

VIPARnd - VIPAR-normoxic-double

$\mathrm{Z}_{\text {ref }}-$ Profundidade de referência 


\section{Capítulo 1 Introdução}




\section{INTRODUÇÃ̃O}

A radioterapia é uma área da medicina na qual a radiação ionizante é utilizada para fins terapêuticos, sendo que sua maior aplicação é o auxílio no tratamento do câncer [1].

A absorção da energia da radiação ionizante (dose) promove dano celular principalmente através da quebra do material genético. Uma característica importante para o tratamento radioterápico é que as células cancerígenas são mais sensíveis aos efeitos da radiação ionizante que as células saudáveis [2].

A radioterapia é divida em duas modalidades: braquiterapia e teleterapia. $\mathrm{Na}$ braquiterapia são utilizadas fontes seladas de materiais radioativos que são colocados em contato direto com o tumor. Para a teleterapia ou radioterapia externa a fonte de radiação fica distante do paciente. Nesta modalidade são usados equipamentos que geram radiação de forma artificial, liberando raios $\mathrm{X}$, elétrons ou prótons, $\mathrm{e}$ equipamentos que usam fontes de isótopo radioativo, como, por exemplo, pastilhas de cobalto 60, que emitem raios gama. Estes aparelhos são usados como fontes externas, com distâncias da superfície do paciente que podem variar de alguns centímetros a metros [3].

Para o sucesso de um tratamento radioterápico é de extrema importância que a dose prescrita seja administrada de forma correta. Em radioterapia externa este item depende não só da integridade mecânica e elétrica dos equipamentos emissores de radiação, mas também da distribuição de dose obtida a partir dos feixes de radiação utilizados [4].

Assim, para que um equipamento possa ser utilizado em radioterapia externa são necessárias medidas dosimétricas dos feixes disponíveis em todas as condições da prática clínica. Essa varredura inicial é chamada de comissionamento do equipamento e os dados dosimétricos coletados serão utilizados para o planejamento dos tratamentos [5]. Como garantia de qualidade do tratamento, estes dados devem ser constantemente verificados. De acordo com as recomendações da International Comission on Radiation Units and Measurements (ICRU) a incerteza máxima global na dose de tratamento é de $\pm 5 \%$ e a máxima variação aceitável na determinação da dose é de $\pm 3 \%[6]$. 
Os avanços tecnológicos na radioterapia externa permitiram o desenvolvimento de técnicas complexas em relação à administração de dose. Os campos de radiação estáticos vem sendo substituídos por campos em que o feixe de radiação é modulado, técnicas chamadas de tratamentos dinâmicos. Em função da modulação, estas técnicas exigem para conferência da distribuição de dose a realização de medidas experimentais que são comparadas com o que foi predito pelo algoritmo de cálculo [7].

Desta forma a realização de medidas dosimétricas é fundamental e faz parte da rotina de um serviço de radioterapia.

Para que um dosímetro seja usado para medidas de distribuição de dose é necessário que a radiação modifique alguma característica física do mesmo e que esta mudança seja quantitativa e proporcional a quantidade de dose. Atualmente existem vários sistemas disponíveis para dosimetria em radioterapia. As características dos dispositivos, tais como exatidão, precisão, repetitividade, reprodutibilidade, intervalo de resposta, condições operacionais, resolução, entre outros, são cruciais para que a sua utilização em uma determinada medida seja adequada [8].

A dosimetria gel foi proposta como uma possibilidade para as medidas de distribuição de dose para os feixes usados em radioterapia [9]. Os dosímetros géis são compostos em sua maior parte por água, apresentando boa equivalência aos tecidos humanos [10], boa resolução e não apresentam dependência angular [9], [11].

Atualmente, existem dois tipos de dosímetros géis: Fricke e gel polimérico. O dosímetro Fricke é composto por sulfato de ferro em uma solução gel aquosa, a irradiação causa a conversão do íon ferroso em íon férrico [12]. O gel polimérico contém monômeros em uma solução gel aquosa que sofrem o processo de polimerização com a presença de radiação através dos radicais livres produzidos pela radiólise [13].

Em ambos os tipos de dosímetros géis as alterações químicas produzidas pela radiação ionizante causam mudanças nas propriedades físico-químicas do material, tais como alteração na coloração, mudança de densidade e de tempo de relaxação de magnetização. Assim, a quantificação da dose pode ser avaliada por diversas técnicas dentre as quais podemos citar espectrofotometria, tomografia óptica e ressonância magnética nuclear [9].

As formulações iniciais para os dosímetros de gel polimérico apresentavam muita dependência do oxigênio atmosférico, composto que pode inibir o processo de polimerização. Devido a esta característica foi necessário a confecção da solução em 
ambientes controlados e livres de oxigênio [9]. Em 2001 Fong et al. propuseram o uso de antioxidantes na solução para reduzir o efeito do oxigênio. O ácido ascórbico foi utilizado para aprisionar o oxigênio livre contido na matriz gelatinosa em um processo iniciado por sulfato de cobre penta hidratado, possibilitando a confecção em ambientes normais de atmosfera [14].

O uso do monômero N-vinilpirrolidona (NPV) em dosimetria gel foi proposto por Pappas et al. em 1999, recebendo o nome de VIPAR. O gel polimérico VIPAR é composto por NVP, N,N'metilenobisacrilamida (BIS), gelatina e argônio, este último usado para remoção de oxigênio na solução [15]. Uma nova composição, o VIPARnd baseado na formulação original, foi descrita por Kozickic et al., 2007, em que a concentração de NPV foi dobrada e foi adicionado na solução sulfato de cobre e ácido ascórbico, eliminando a necessidade de um gás inerte para remoção do oxigênio [16].

A resposta do material pode ser alterada tanto pela escolha dos produtos químicos usados em sua composição como pela concentrações destes. Além disso a metodologia experimental e fatores externos tais como temperatura e luz também tem papel importante para a caracterização e aplicação do dosímetro gel [9].

Desta forma a compreensão das propriedades físico-químicas do material e das modificações decorrentes da interação com a radiação ionizante, assim como a identificação de como os parâmetros experimentais, condições externas e sistema de leitura interferem na resposta do material são de fundamental importância para avaliar a viabilidade do sistema dosimétrico.

\subsection{Objetivos do Trabalho}

\subsubsection{Objetivo Geral}

Avaliação dosimétrica do gel VIPARnd usando a técnica de espectrofotometria na região visível e ultra-violeta e imagens com câmera com sensor CMOS para aplicação clínica na dosimetria de Raios X de alta energia. 


\subsubsection{Objetivos Específicos}

- Padronizar o método de confecção do gel VIPARnd para dosimetria em radioterapia;

- Estudar os parâmetros que alteram a resposta do dosímetro gel;

- Realizar testes de desempenho do dosímetro gel em feixes de Raios X de alta energia tais como: sensibilidade, reprodutibilidade, estabilidade da resposta, resposta em função da dose.

\subsubsection{Objetivos Complementares}

- Apresentar possível aplicação da dosimetria com gel VIPARnd usando imagens com câmera de sensor CMOS para realização de medidas em braquiterapia; medidas de perfil de campos pequenos e PDP em radioterapia externa;

- Estudar possível aplicação da dosimetria com gel VIPARnd utilizando imagens de tomografia computadorizada.

\subsection{Estrutura do Trabalho}

O primeiro capítulo tem caráter introdutório com apresentação dos objetivos e da estrutura do trabalho.

No segundo capítulo é apresentada uma revisão bibliográfica sobre os aspectos principais do trabalho. Será feita uma abordagem sobre aceleradores lineares para uso clínico, dosimetria, dosimetria gel e principais características do dosímetro estudado neste trabalho.

O terceiro capítulo trata da parte experimental, onde estão descritos a metodologia para confecção, armazenamento, irradiação e leitura do dosímetro gel.

O quarto capítulo apresenta os resultados obtidos através dos dados coletados e as discussões sobre estes resultados.

Por fim, as principais conclusões advindas dessa pesquisa e algumas sugestões para trabalhos futuros. 


\section{Capítulo 2 \\ Revisão Bibliográfica}




\section{REVISÃO BIBLIOGRÁFICA}

\subsection{Aceleradores Lineares Clínicos}

Dentre os equipamentos utilizados atualmente para radioterapia externa (teleterapia) os aceleradores lineares são os mais comuns. Estes equipamentos podem produzir para fins terapêuticos feixes de elétrons e de fótons (raios X) de alta energia. Os aceleradores lineares utilizam ondas de radiofrequência (RF) e potencial elétrico para aceleração de elétrons. As ondas de RF geradas penetram juntamente com os feixes de elétrons no tubo de aceleração. A velocidade da onda aumenta progressivamente e os elétrons são carregados por estas ondas e acelerados [3]. Ao sair do tubo de aceleração o feixe de elétrons tem sua direção alterada por um conjunto de eletroímãs que direciona o feixe para baixo como mostrado na Figura 1.

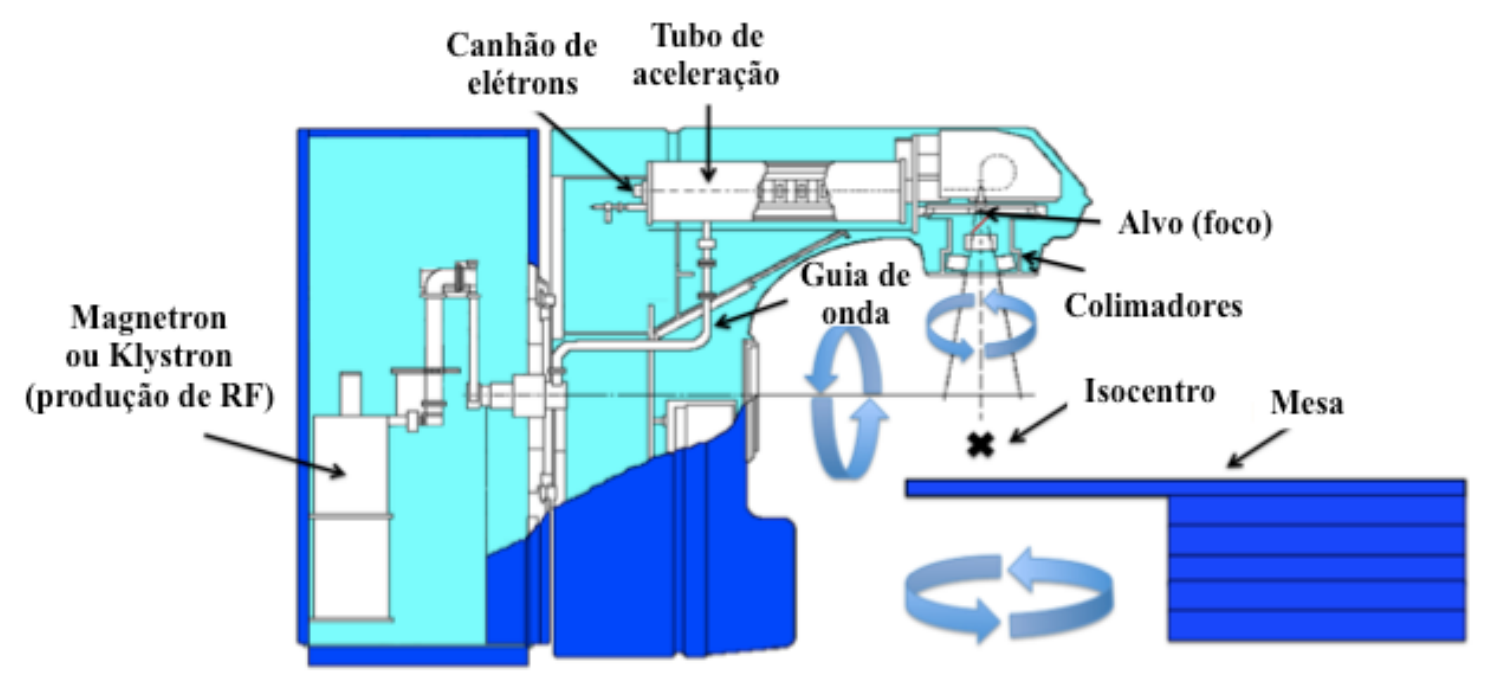

Figura 1 - Esquema de um Acelerador Linear para Radioterapia.

Na produção de raios $\mathrm{X}$ o feixe de elétrons é acelerado em direção a um alvo metálico, geralmente de tungstênio. A posição do alvo dentro do acelerador linear é também chamada de foco ou fonte, uma vez que para feixes de raios $\mathrm{X}$ é a partir deste ponto que começa a produção de radiação. Para garantir homogeneidade ao longo do campo de radiação é utilizado um filtro achatador (Figura 2a).

Para a utilização do feixe de elétrons, o alvo é removido e o filtro achatador é substituído por uma folha espalhadora, que tem o intuito de alargar o feixe de elétrons que inicialmente é muito fino para fins terapêuticos (Figura 2b). 


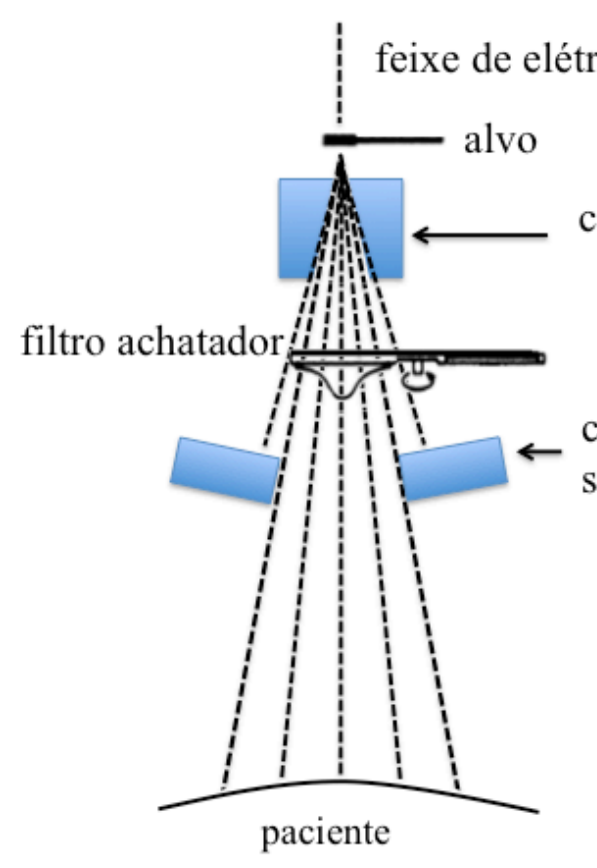

(a)

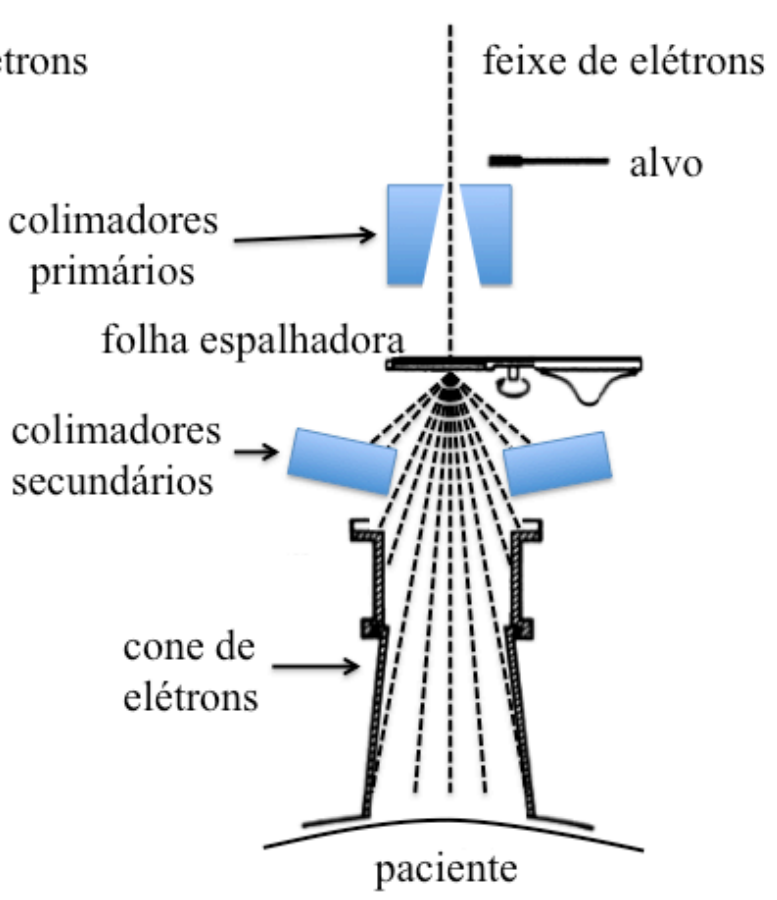

(b)

Figura 2 - Esquema do cabeçote de um Acelerador Linear para Radioterapia. (a) Esquema para produção de Raios X, (b) esquema para a utilização do feixe de elétrons.

A delimitação do feixe é feita por um sistema de colimadores. Nos aceleradores lineares temos um sistema primário de colimação que serve para definir o feixe útil e o sistema de colimação secundária, responsável pela delimitação do tamanho de campo, conforme mostrado na Figura 2. O colimador secundário é formado por blocos de tungstênio, que se movem formando aberturas retangulares ou quadradas [5].

A utilização de colimações diferentes das retangulares e quadradas são mais comuns, já que na maior parte das vezes os volumes de tratamento possuem formatos irregulares, para tal é necessário um terceiro sistema de colimação.

Para os feixes de fótons de alta energia existem duas possibilidades: os blocos e o colimadores multilâminas. Os blocos são confeccionados com ligas de chumbos e acoplados a bandejas encaixadas na cabeça do equipamento. Já os colimadores multilâminas (MLC - MultiLeaf Collimator) são formados por um conjunto de lâminas, que se movem independentemente umas das outras através de motores individuais controlados por computador, possibilitando diferentes formatos de campo [17].

Quando o feixe de elétrons é utilizado, nos equipamentos com esta possibilidade, além dos sistemas de colimadores primário e secundário, são acoplados um colimador externo ao acelerador, usualmente chamados de cones, que ficam bem próximos ao 
paciente. Como o feixe de elétrons tem por característica um alto poder de espalhamento é necessário um sistema de colimação que fique mais próximo do alvo. Para colimações adicionais também são usados blocos de liga de chumbo, que são encaixados no próprio cone [3].

A cabeça do acelerador linear rotaciona $360^{\circ}$, o ponto central do eixo de rotação é chamado de isocentro e para os equipamentos mais novos a distância da fonte (foco) até o isocentro é igual a $100 \mathrm{~cm}[5]$.

\subsection{Grandezas e parâmetros dosimétricos}

Os efeitos da radiação ionizante sobre a matéria dependem não só do tipo de radiação, mas também das interações que ocorrem. As grandezas dosimétricas fornecem uma medida física dos processos pelos quais a energia de uma partícula do feixe de radiação é convertida e depositada na matéria [18].

A grandeza dosimétrica mais utilizada em radioterapia para medida da dose de radiação é a dose absorvida. A dose absorvida $D$ em um ponto é definida como o valor da energia cedida ao meio $d E$, num volume de massa $d m$ :

$$
D=\frac{d E}{d m}
$$

A unidade de dose absorvida no sistema internacional é o $\mathrm{J} / \mathrm{Kg}$, e recebe o nome de Gray (Gy).

A interação de fótons em um dado material depende de seu número atômico efetivo e da energia do feixe. Os principais processos de interação do feixe de fótons com a matéria são: Efeito Fotoelétrico, Espalhamento Compton e Produção de Pares [19]. Estes processos depositam energia no meio de forma indireta, primeiramente a energia dos fótons é transferida para partículas carregadas e na segunda etapa as partículas carregadas interagem com outras partículas carregadas transferindo energia para o meio e depositando dose [20].

Assim, a transferência de energia para o meio por um feixe de fótons não ocorre na mesma localização espacial em que a energia é absorvida. Este fato traz implicações para o cálculo de dose absorvida [18]. 
Se considerarmos que o feixe de fótons atinge o meio sem que haja interações anteriores ao mesmo, teoricamente não haveria dose na superfície deste meio. Porém, o feixe de fótons clínico para radioterapia externa ao ser produzido interage com os componentes do equipamento gerador e também com o ar, antes de atingir o meio. Estas interações e o retroespalhamento dentro do meio são responsáveis pela dose na superfície, que para feixes de alta energia é baixa [21]. Assim no instante em que o feixe incide sobre o meio, não há uma relação constante entre o número de partículas carregadas que entra e sai do volume. À medida que a profundidade no meio aumenta, a relação entre as cargas que entram e saem do volume tendem ao equilíbrio, até se igualarem. Esta situação é conhecida como equilíbrio de partículas carregadas (EPC). A dose aumenta rapidamente com o aumento da profundidade no meio, até atingir um valor máximo, exatamente no ponto em que se atinge o EPC (profundidade de máxima dose). A distância da superfície até o ponto de máximo é chamada de região de build up como mostrado na Figura 3. Após a condição de equilíbrio ser alcançada a dose volta a cair devido a diminuição na geração de elétrons secundários. Essa faixa é chamada de região de equilíbrio transiente de partículas carregadas (ETPC) [18].

A representação gráfica da dose no raio central em função da profundidade recebe o nome de curva de porcentagem de dose em profundidade (PDP). A PDP é característica do tipo e da energia do feixe de radiação e sua determinação faz parte das medidas necessárias para utilização clínica do feixe de radiação. O tamanho do campo de radiação modifica a PDP medida, pois o aumento do campo gera um aumento na quantidade de radiação espalhada e consequentemente na dose medida. Para um feixe de fótons quanto maior a energia do feixe, menor a dose na superfície, maior a profundidade de máxima dose e maior a penetração do feixe [5]. 


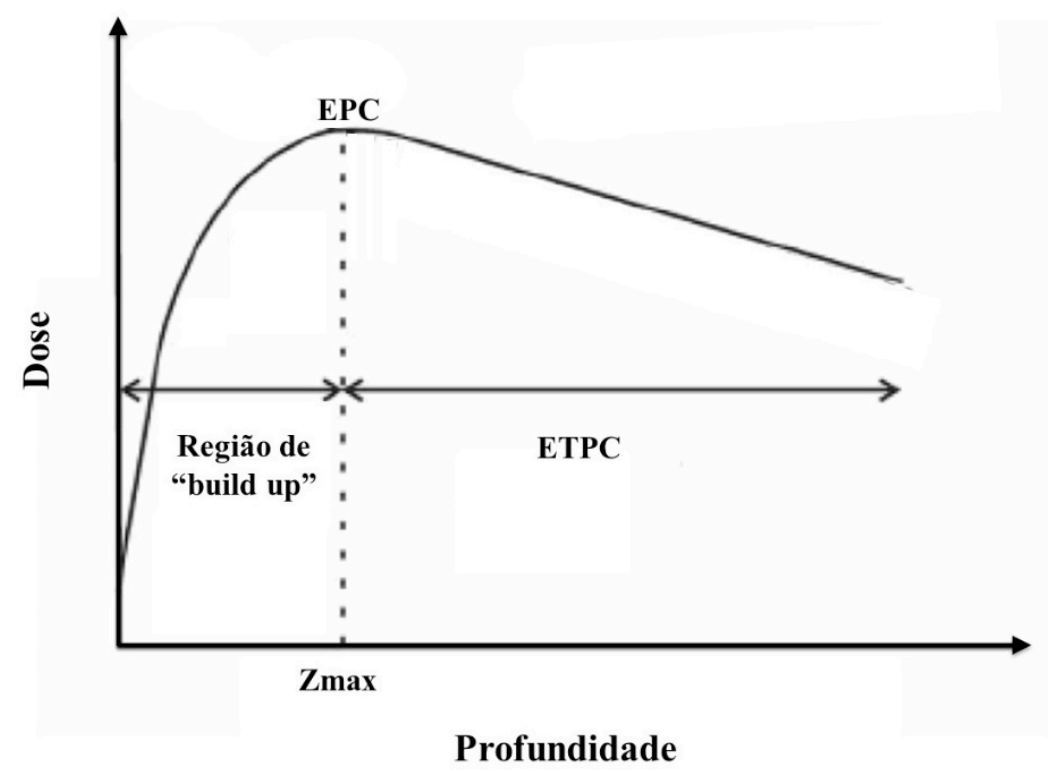

Figura 3 - Gráfico da dose absorvida em função da profundidade, indicando as regiões de build up, EPC e ETPC.

Além da distribuição de dose em profundidade ao longo do eixo central (PDP) são necessárias medidas ao longo de todo o campo de irradiação. A distribuição de dose em duas ou três dimensões é dada a partir dos perfis de dose em diferentes pontos ou planos do campo de radiação, esta representação gráfica é conhecida como curvas de isodoses [17].

Para um feixe de elétrons as interações são decorrentes das forças de interação coulombiana, por se tratar de partículas carregadas. A transferência de energia do feixe de elétrons para o meio se dá por colisões elásticas ou inelásticas com os elétrons ou com os núcleos dos átomos do meio. Para feixes de elétrons de alta energia incidindo em materiais de médio número atômico, como é o caso do tecido humano e da água as interações predominantes são as colisões com os elétrons dos átomos do meio. À medida que o feixe de elétrons se desloca através do meio a energia diminui constantemente até que os elétrons atingem energia térmica e são capturados pelos átomos circundantes [3]. Desta forma a deposição de dose para um feixe de elétrons tem início assim que os elétrons incidem sobre o paciente e permanece mais ou menos constante até uma queda abrupta, tornando-os bastante úteis para tratamentos superficiais. Para os feixes de elétrons, quanto maior a energia, maior a dose na superfície, maior a profundidade de máxima dose e maior a penetração [5]. 


\subsection{Código de práticas para dosimetria de fótons e elétrons de alta energia}

A Agência Internacional de Energia Atômica (IAEA - International Atomic Energy Agency) estabelece recomendações para padronização da dosimetria de feixes clínicos. Dentre suas publicações, o código de práticas atual é o Technical Report Series (TRS) $n^{\circ} .398$ [22].

O TRS 398 recomenda a água como meio para realização de medidas de feixes clínicos de fótons e elétrons de alta energia.

A qualidade do feixe para fótons de alta energia, $\mathrm{K}_{\mathrm{Q}, \mathrm{Q} 0}$, é definida pelo TRS 398 através do $\mathrm{TPR}_{20,10}$, que corresponde a razão da relação tecido meio (TPR - tissue phantom ratio) na profundidade de $20 \mathrm{~cm}$ com o TPR na profundidade de $10 \mathrm{~cm}$. O TPR é um parâmetro dosimétrico que por definição estabelece uma relação entre a dose no objeto simulador e a dose no paciente. Este parâmetro é estabelecido através da razão entre a dose na profundidade de $20 \mathrm{~cm}$ pela dose na profundidade de $10 \mathrm{~cm}\left(\mathrm{PDP}_{20,10}\right)$, através da equação (2):

$$
\mathrm{TPR}_{20,10}=1,2661 \times \mathrm{PDP}_{20,10}-0,0595
$$

$\mathrm{O}$ valor de $\mathrm{TPR}_{20,10}$ é usado como critério para definição das condições de referência para determinação da dose absorvida. A fim de eliminar a dependência do meio a profundidade é comumente expressa em $\mathrm{g} / \mathrm{cm}^{2}$ (produto da unidade de comprimento pela densidade do meio). Para medidas com câmaras de ionização o TRS 398 recomenda uma profundidade de $5 \mathrm{~g} / \mathrm{cm}^{2}$ a $10 \mathrm{~g} / \mathrm{cm}^{2}$ para medidas de feixes com $\mathrm{TPR}_{20,10}<0,7$ e uma profundidade de $10 \mathrm{~g} / \mathrm{cm}^{2}$ para feixes com $\mathrm{TPR}_{20,10} \geq 0,7$.

$\mathrm{O}$ índice de qualidade para feixes de elétrons utilizados para dosimetria é a profundidade na qual a dose absorvida corresponde a $50 \%$ da dose máxima $\left(R_{50}\right)$. Para medidas com câmara de ionização o valor de $\mathrm{R}_{50}$ é relacionado com a profundidade na qual se tem uma leitura de carga correspondente a $50 \%$ do valor máximo $\left(R_{50, \text { ion }}\right)$ através das equações mostradas em (3):

$$
\begin{array}{llll}
R_{50}=1,029 R_{50, \text { ion }}-0,06 & \left(\mathrm{~g} / \mathrm{cm}^{2}\right) & \text { para } & R_{50, \text { ion }} \leq 10 \mathrm{~g} / \mathrm{cm}^{2} \\
R_{50}=1,059 R_{50, \text { ion }}-0,37 & \left(\mathrm{~g} / \mathrm{cm}^{2}\right) & \text { para } & R_{50, \text { ion }}>10 \mathrm{~g} / \mathrm{cm}^{2}
\end{array}
$$


A profundidade de referência $\left(z_{r e f}\right)$ que deve ser usada para a calibração do feixe de elétrons é determinada em função do valor de $R_{50}$, conforme mostrado na equação (4):

$$
z_{\text {ref }}=0,6 R_{50}-0,1 \quad\left(\mathrm{~g} / \mathrm{cm}^{2}\right)
$$

\subsection{Dosimetria}

A quantificação de grandezas dosimétricas, chamada de dosimetria, é realizada com a utilização de instrumentos ou materiais que sofrem alguma alteração na presença de radiação ionizante. Estes instrumentos e materiais recebem o nome de dosímetros, com os quais é possível medir alguma grandeza que possa ser relacionada com uma grandeza dosimétrica [20].

Os dosímetros mais utilizados na rotina clínica em radioterapia são as câmaras de ionização, devido à excelente precisão e exatidão da resposta. São consideradas como dosímetro padrão para calibração dos feixes de radiação [3].

Dosímetros de estado sólido também são utilizados, tais como, os termoluminescentes e diodos. Os diodos, por sua alta resolução espacial, possuem aplicação em medidas de campos pequenos. Já os termoluminescentes são mais usados para medidas de dose de entrada e saída na pele [8].

Com a inclusão de tratamentos dinâmicos e a necessidade de medida da distribuição de dose dos campos de radiação como garantia da qualidade do tratamento, tornou-se necessário a utilização de dosímetros que fossem capazes de realizar medidas em dimensões espaciais cada vez maiores. Um dos primeiros dosímetros utilizados para conferência da distribuição de dose destes tratamentos dinâmicos foi o filme radiográfico, que permite medidas planares (bidimensionais - 2D). Um segundo tipo de filme foi desenvolvido, o radiocrômico. Atualmente existem no mercado detectores formados por matriz de câmaras de ionização ou matriz de diodos, que também permitem medidas em 2D [23], [24]. Esta avaliação bidimensional da dose é uma boa aproximação, mas não representa a real distribuição de dose, uma vez que o planejamento do tratamento é realizado através de distribuições de dose tridimensionais (3D), previstas por algoritmos computacionais em imagens volumétricas [1]. 
Para avaliação 3D da dose foram propostos os dosímetros gel, compostos em sua maior proporção de gelatina aquosa. Esta composição se assemelha à composição do tecido humano e favorece a comparação de dose [10].

\subsubsection{Dosimetria gel}

Atualmente existem dois tipos de dosímetros gel sendo estudados: Fricke e polímeros [25].

O Fricke gel apresenta agregado à matriz gelatinosa, sulfato ferroso. A interação com a radiação ionizante muda o estado de oxidação do ferro, formando íons de $\mathrm{Fe}^{3+} \mathrm{e}$ assim alterando a composição química e a coloração do material. Uma limitação do Fricke gel é um borramento do sinal devido à alta difusão iônica pós irradiação e a oxidação espontânea que ocasionam perda na resolução espacial. Compostos como ácido benzóico e alaranjado de xilenol foram adicionados na formulação original com o intuito de aumentar a sensibilidade do dosímetro gel. As características paramagnéticas do íons férricos alteram o tempo de relaxação dos spins possibilitando a utilização da Ressonância Magnética Nuclear (RMN) como método de leitura de dose para este dosímetro. A alteração na coloração do material causada pela radiação também sugere o emprego de técnicas ópticas como espectrofotometria e tomografia de coerência óptica (TCO) [26].

O gel polimérico contém monômeros em uma solução gel aquosa. A radiação provoca a quebra das ligações de carbono nos monômeros através da interação com os radicais livres produzidos pela radiólise da água, permitindo o processo de polimerização através de ligações cruzadas entre os radicais. Este processo altera as propriedades físico-químicas da solução em função da dose absorvida e uma característica visível é a alteração de cor, à medida que a dose aumenta, maior a opacidade do material [13].

A polimerização e as reações de ligações cruzadas nas formulações iniciais dos géis poliméricos eram inibidas pela presença de oxigênio. Desta forma foi necessário que a confecção do gel fosse realizada em ambiente livre de oxigênio ou com a utilização de gás inerte para remoção do oxigênio, trata-se dos géis poliméricos anóxicos [9]. Esta dependência com o oxigênio foi substancialmente reduzida com a utilização de agentes antioxidantes na solução, tais como ácido ascórbico e 
tetrahidroxifenilclorina (THPC). A inserção destes agentes possibilitou a confecção dos géis poliméricos em ambientes normais de atmosfera, estes são chamados de gel normóxidos [14], [27].

A resposta em função da dose e a sensibilidade dos dosímetros gel dependem da concentração dos monômeros na solução, assim como da sua exposição ao oxigênio e a temperatura durante a confecção, irradiação e leitura do material [28]. Os géis poliméricos apresentam boa estabilidade temporal pós-irradiação, o sinal se mantém praticamente estável até um mês após a irradiação [29].

A dosimetria por gel polimérico foi estudada para diferentes tipos de radiação usados em radioterapia, como radiação gama de fontes de Cobalto 60, raios $\mathrm{X}$ e elétrons de alta energia, estes usados em radioterapia externa, assim como para feixes produzidos por fontes usadas em braquiterapia. Os estudos mostram boa resolução espacial para estes tipos de feixes de radiação [9].

Para fótons e elétrons de alta energia os trabalhos não mostram dependência energética [30], [11].

Investigações também foram realizadas para medidas de dose em tratamentos com alto gradiente de dose, tais como Radioterapia de Intensidade Modulada (IMRT) [31], [32], Radioterapia em Arco de Intensidade Modulada (IMAT) [33], [34], radiocirurgia (SRS) [35], [36] e braquiterapia de alta taxa de dose [37].

Os géis poliméricos também foram empregados para feixe de prótons [38] e de neutrôns [39].

Para avaliar a distribuição de dose em dosímetros com gel polimérico várias modalidades de imagem por ser utilizadas. A opacidade causada pela radiação proporciona contraste óptico, que pode ser detectado através de técnicas de espectrofotometria óptica, imagens com câmeras com sensor CCD (Charge-Coupled Device) ou CMOS (Complementary Metal-Oxide Semiconductor) e tomografia de coerência óptica (TCO) [40], [41]. As medidas com espectrofotometria óptica mostram aumento da absorvância a medida que a dose absorvida aumenta [41]. O uso de imagens com câmera de sensor CCD ou CMOS foram empregadas para medidas de PDP e perfil de dose, apresentando boa resolução [40]. A TCO é uma possibilidade para medidas 3D [42]. Devido a metodologia simples a espectroscopia no intervalo de comprimentos de ondas de luz visível é bastante utilizada para análise da resposta de diferentes composições dos dosímetros [43].

Medidas com imagens por ressonância magnética nuclear (IRM) [13], com 
tomografia computadorizada (TC) por raios X [44] e ultrassom [45] também foram utilizados para avaliação da distribuição tridimensional (3D) de dose.

MRI é a modalidade de leitura mais utilizada para dosimetria com gel polimérico, pois o processo de polimerização altera as taxas de relaxação de magnetização em função da formação das cadeias poliméricas. Estas cadeias influenciam na mobilidade das moléculas de água, alterando então a mobilidade dos átomos de $\mathrm{H}$ e alterando o sinal em MRI. As medidas da taxa de relaxação spin-spin $(\mathrm{R} 2=1 / \mathrm{T} 2)$ apresentam maior sensibilidade que as medidas de relaxação spin-rede $(\mathrm{R} 1=1 / \mathrm{T} 1)$. Usando uma série de sequências com diferentes valores de tempo de eco (TE) em imagens ponderadas em T2 pode ser calculado o valor de R2 [46].

O uso de imagens de TC para avaliação da resposta em função da dose nos géis poliméricos foi proposto recentemente. A densidade do material é alterada com a polimerização causada pela radiação, com o aumento da dose a densidade do gel é aumentada, e consequentemente ocorre o aumento no número TC. Entretanto, este método de leitura apresenta uma resolução e sensibilidade reduzida quando comparada à IRM e TCO [47].

A alteração da velocidade acústica no gel com a absorção de dose foi identificada com medidas de ultrassom. Essas mudanças são decorrentes da alteração da densidade mássica do composto ocasionada pelas interações decorrentes da radiação ionizante [45].

\subsection{Dosímetros gel baseados em N-vinilpirrolidona (NPV)}

Pappas et al. em 1999 propuseram o uso do monômero N-vinilpirrolidona (NPV) em dosimetria gel. Nesta formulação a N,N'metilenobisacrilamida (BIS) atua como agente reticulador e gás argônio foi utilizado para a remoção do oxigênio durante a confecção e preenchimento dos tubos com gel [15]. Este gel recebeu o nome de VIPAR ( $N$-vinylpyrrolidone argon). A composição do VIPAR usada nesta referência foi $4 \% \mathrm{~m} / \mathrm{m}$ de NVP, $4 \% \mathrm{~m} / \mathrm{m}$ de BIS, $5 \% \mathrm{~m} / \mathrm{m}$ de gelatina tipo A (300 Bloom) e $87 \% \mathrm{~m} / \mathrm{m}$ de água. Utilizou-se um feixe de raios X de $6 \mathrm{MV}$ produzido por um acelerador linear, estudando doses de 0 a 11 Gy com leituras realizadas através de imagens por ressonância magnética (IRM) com ponderação em T2. O dosímetro gel apresentou curva de dose-resposta com comportamento linear de 2 a 11 Gy e boa resolução para 
análise da distribuição de dose.

Baras et al. em 2002 mostraram a aplicação do gel VIPAR para avaliação da distribuição de dose com fontes de irídio 192 usadas em braquiterapia de alta taxa de dose [37]. A leitura foi realizada com IRM e os resultados mostraram que o gel apresenta boa resolução espacial para a distribuição de dose com a fonte radioativa utilizada.

Em 2007 uma nova formulação foi proposta for Kozickic et al., o VIPARnd, em que as concentrações de NVP e de gelatina foram aumentadas e foi acrescentado na solução sulfato de cobre penta hidratado $\left(\mathrm{CuSO}_{4} \cdot \mathrm{H}_{2} \mathrm{O}\right)$ e ácido ascórbico (ASC). O gel era composto por NVP $(8 \% \mathrm{~m} / \mathrm{v})$, BIS $(4 \% \mathrm{~m} / \mathrm{v})$, gelatina tipo A - 300 Bloom $(7,5 \% \mathrm{~m} / \mathrm{v}), \mathrm{CuSO}_{4} \cdot \mathrm{H}_{2} \mathrm{O}(0,0008 \% \mathrm{~m} / \mathrm{v}), \operatorname{ASC}(0,007 \% \mathrm{~m} / \mathrm{v})$ e foi irradiado com feixe de raios X de $6 \mathrm{MV}$ [16]. O aumento na concentração do NVP foi sugerido para deixar o gel mais sensível para doses mais baixas, diminuindo o mínimo valor de dose detectável. Nesta referência a resposta com IRM se mostrou linear no intervalo de 1 a 40 Gy e a completa saturação do gel ocorreu com 120 Gy. A adição de ácido ascórbico e sulfato de cobre penta hidratado foi baseado nos relatos de Fong et al. em 2001, que propôs o uso destes compostos com o intuito de minimizar a influência do oxigênio nas reações de polimerização [14]. O cobre atua como um catalisador na eliminação do oxigênio, através da oxidação do acido ascórbico. Papadakis et al. em 2007 utilizaram outro antioxidante em soluções com NVP, a tetrahidroxifenilclorina (THPC), esta formulação foi chamada de VIPET [48].

Estudos realizados com o VIPET em 2013 [49] avaliaram a influência da concentração de NVP no gel, testando duas concentrações, a primeira, VIPET1v, com $4 \% \mathrm{~m} / \mathrm{m}$ e a VIPET2v com $8 \% \mathrm{~m} / \mathrm{m}$. O VIPET1v exibiu resposta linear entre 2 e 60 Gy e o VIPET2v na faixa de 1 a 30 Gy (ambos com leituras através de IRM, para feixes de raios X de $6 \mathrm{MV})$, confirmando que a concentração do monômero altera a resposta do gel. As análises realizadas com o VIPET mostraram que o tempo entre a confecção do gel e sua irradiação interferem na resposta do gel, o gel apresenta degradação considerável para intervalos maiores que 1 semana [50]. Em contrapartida a resposta não é alterada com um tempo pós-irradiação de até 1 mês [49], [50]. 


\subsubsection{Características químicas dos componentes do dosímetro gel tipo VIPARnd.}

Conforme descrito no item 2.5 o VIPARnd é composto por N-vinilpirrolidona (NPV), N,N'metilenobisacrilamida (BIS), gelatina tipo A 300 Bloom, água, ácido ascórbico (ASC) e sulfato de cobre penta hidratado $\left(\mathrm{CuSO}_{4} \cdot \mathrm{H}_{2} \mathrm{O}\right)$.

\subsubsection{Monômero e agente reticulador}

O N-vinilpirrolidona (NPV) é o monômero da polivinilpirrolidona, possui massa molar de 111,14 g/mol, densidade de $1,043 \mathrm{~g} / \mathrm{cm}^{3}$ e fórmula molar $\mathrm{C}_{6} \mathrm{H}_{9} \mathrm{NO}$.

O N,N'metilenobisacrilamida (BIS) é um agente de ligações cruzadas utilizado na formulação de alguns dosímetros do tipo gel polimérico. A sua fórmula molar é $\mathrm{C}_{7} \mathrm{H}_{10} \mathrm{~N}_{2} \mathrm{O}_{2}$, possui massa molar de $154,17 \mathrm{~g} / \mathrm{mol}$ e densidade de $1,230 \mathrm{~g} / \mathrm{cm}^{3}$.

As estruturas das moléculas do NVP e do BIS são mostradas na Figura 4.

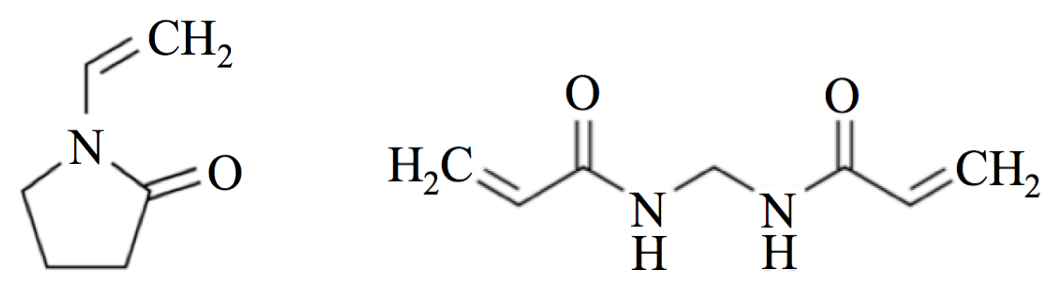

Figura 4 - Estruturas químicas do NPV (esquerda) e do BIS (direita).

\subsubsection{Gelatina tipo A 300 Bloom}

A gelatina é composta por aminoácidos ligados por ligações peptídicas. A do tipo A é derivada da hidrólise parcial do colágeno, produzida a partir de pele ou ossos de porcos. Trata-se de uma sustentação mecânica para os componentes da solução.

\subsubsection{Agentes Antioxidantes}

O ácido ascórbico possui ação antioxidante e é usado para transformar os radicais livres de oxigênio em formas inertes. Possui densidade de $1,65 \mathrm{~g} / \mathrm{cm}^{3}$, massa molar de $176,09 \mathrm{~g} / \mathrm{mol}$ e a sua fórmula molar é $\mathrm{C}_{6} \mathrm{H}_{8} \mathrm{O}_{6}$. 
$\mathrm{O}$ sulfato de cobre pentahidratado $\left(\mathrm{CuSO}_{4} .5 \mathrm{H}_{2} \mathrm{O}\right)$ possui massa molar de $249,685 \mathrm{~g} / \mathrm{mol}$ e densidade de $2,286 \mathrm{~g} / \mathrm{cm}^{3}$. A alta reatividade do íon metálico $\mathrm{Cu}^{+2}$ ativado pelo ácido ascórbico provoca o consumo das moléculas de oxigênio livre.

A necessidade de utilização de agentes oxidantes se deve a interferência do oxigênio no processo de polimerização. Mesmo pequenas quantidades de oxigênio podem inibir reações de copolimerização de radicais livres em dosímetros de gel polimérico [51]. Os radicais peróxidos criados por reações do oxigênio com cadeias poliméricas crescentes como mostrado na Figura 5 faz com que estas cadeias fiquem não reativas para outras reações de polimerização.

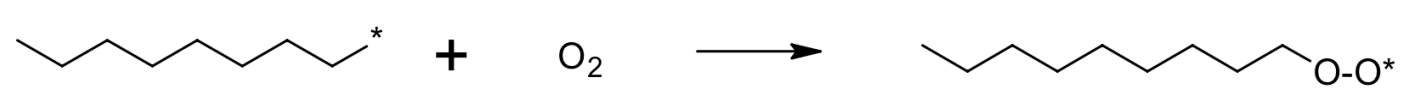

Figura 5 - Esquema de formação do radical peróxido através da interação do oxigênio com uma parte da cadeia polimérica.

\subsubsection{4. Água}

A água utilizada é pura, obtida através dos processos de destilação e deionização, para que não haja outras substâncias que possam interferir no processo de polimerização, tais como sais minerais e íons [9].

\subsubsection{Reações químicas no gel dosímetro tipo VIPARnd}

\subsubsection{Radiólise da água}

Como a água é o composto em maior concentração dentro da solução do dosímetro, é a molécula com maior probabilidade de interação com a radiação. A radiação $(h v)$ ocasiona ionização nas moléculas de água, fenômeno chamado de radiólise [20]. A quebra inicial na molécula de água acontece de acordo com a expressão (5):

$$
\mathrm{H}_{2} \mathrm{O}+h v \rightarrow \mathrm{H}_{2} \mathrm{O}^{+}+e^{-}
$$


O íon positivo formado a partir da reação mostrada em (5) pode formar o radical hidroxil $\left(\mathrm{OH}^{\bullet}\right)$ ao se dissociar na forma:

$$
\mathrm{H}_{2} \mathrm{O}^{+} \rightarrow \mathrm{H}^{+}+\mathrm{OH}^{\cdot}
$$

Os elétrons livres $\left(e^{-}\right)$podem atacar uma molécula neutra de água e formar o radical hidrogênio $\left(H^{\bullet}\right)$ através da seguinte reação:

$$
\mathrm{H}_{2} \mathrm{O}+e^{-} \rightarrow \mathrm{H}_{2} \mathrm{O}^{-} \rightarrow \mathrm{H}^{\cdot}+\mathrm{OH}^{-}
$$

Os radicais hidrogênio e hidroxil também podem ser formados através da excitação da molécula de água:

$$
\mathrm{H}_{2} \mathrm{O} \rightarrow \mathrm{H}_{2} \mathrm{O}^{*} \rightarrow \mathrm{H}^{\bullet}+\mathrm{OH}^{\bullet}
$$

Assim, como resultado das reações de radiólise temos um par de íons $\mathrm{H}^{+}$e $\mathrm{OH}^{-}$e um par de radicais livres $H^{\circ}$ e $O H^{\circ}$.

$\mathrm{O}$ radical livre $H^{\bullet}$ se combina com o oxigênio molecular para formar o radical hidroperoxil:

$$
\mathrm{H}^{\bullet}+\mathrm{O}_{2} \rightarrow \mathrm{HO}_{2}^{\cdot}
$$

A combinação de dois radicais livres $\mathrm{OH}^{\bullet}$ forma o peróxido de hidrogênio:

$$
\mathrm{OH}^{\bullet}+\mathrm{OH}^{\bullet} \rightarrow \mathrm{H}_{2} \mathrm{O}_{2}
$$

O peróxido de hidrogênio também pode ser formado através da interação entre dois radicais hidroperoxil como mostrado em (11):

$$
\mathrm{HO}_{2}^{\bullet}+\mathrm{HO}_{2}^{\bullet} \rightarrow \mathrm{H}_{2} \mathrm{O}_{2}+\mathrm{O}_{2}
$$

Os radicais hidroperoxil e o peróxido de hidrogênio são considerados produtos altamente nocivos e podem reduzir ou oxidar as demais moléculas do meio. Além disso, 
os elétrons livres podem através da polarização das moléculas próximas a água, formar um elétron-hidratado $\left(\mathrm{e}_{\mathrm{aq}}^{-}\right)$de vida relativamente longa [20].

\subsubsection{Reação de polimerização}

O dosímetro gel VIPARnd é uma gelatina hidrogel na qual os monômeros N-vinilpirrolidona (NPV) e N,N'metilenobisacrilamida (BIS) são dissolvidos. Quando o gel é irradiado as moléculas de água são ionizadas conforme descrito no item 2.5.2.1. Os radicais livres e os elétrons-hidratados $\left(\mathrm{e}_{\mathrm{aq}}^{-}\right)$causam a quebra da dupla ligação do carbono nas moléculas dos monômeros.

As quebras na molécula do BIS foram descritas por Kozicki et al. em 2003 [52]. Nas reações mostradas em (12), (13) e (14) as quebras da dupla ligação do carbono no BIS são ocasionadas através da interação com os radicais hidrogênio $\left(H^{\bullet}\right)$ e hidroxil $\left(\mathrm{OH}^{\circ}\right)$ e com elétron-hidratado $\left(\mathrm{e}_{\mathrm{aq}}^{-}\right)$, respectivamente:<smiles>C=CC(=O)NC[CH2+]</smiles><smiles>C=CC(=O)NC[CH+]OCCO</smiles><smiles>C=CC(=O)NC[14C]NC(=O)C=C</smiles> 
Através da protonação o ânion formado a partir da reação (14) pode atingir um estado fundamental de menor energia (equilíbrio molecular) como mostrado por Kozicki et al. em 2003 [52]:<smiles>C=CC(=O)NCNC(=O)C=C</smiles>

No NVP as reações com os radicais livres produzidos pela radiólise da água podem formar os radicais mostrados na Figura 6 [53].
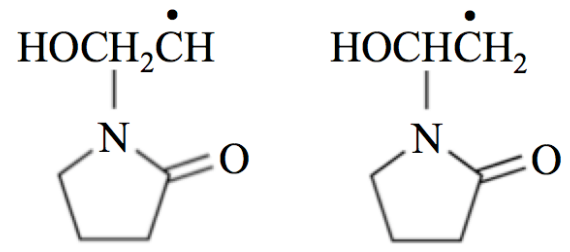

Figura 6 - Radicais formados a partir da interação do NVP com os radicais livres gerados a partir da radiólise da água

A partir das possíveis quebras na moléculas de NVP e BIS, conforme mostrado anteriormente, várias reações subsequentes podem ocorrer formando na solução uma série de radicais cromonômeros na solução. Estes cromonômeros reagem entre si para formar cadeias poliméricas [52].

Devido à alta fração de agentes de ligação cruzada a estrutura final do polímero é uma rede tridimensional. O grau de polimerização é diretamente proporcional à dose absorvida. E, devido a matriz gelatinosa, os agregados poliméricos não podem se difundir na estrutura do gel preservando a informação espacial da absorção de dose. 


\section{Capítulo 3 Materiais e Métodos}




\section{MATERIAIS E MÉTODOS}

\subsection{Materiais}

O VIPARnd foi preparado usando NVP (pureza $\geq 99 \%$, Sigma Aldrich), BIS (Sigma Aldrich), gelatina tipo A 300 Bloom (Sigma Aldrich), $\mathrm{CuSO}_{4} .5 \mathrm{H}_{2} \mathrm{O}$ (Dinâmica Química Contemporânia Ltda) e ácido ascórbico (Dinâmica Química Contemporânia Ltda) e água ultra pura (milli-Q).

\subsection{Confecção e armazenamento do gel}

A preparação da solução foi realizada de acordo com a metodologia descrita por Kozickic et al., 2007 [16].

$\mathrm{O}$ BIS e a gelatina foram dissolvidos em água aquecida a $50^{\circ} \mathrm{C}$ com agitação magnética. Após a dissolução completa do BIS e da gelatina o aquecimento foi desligado e a solução mantida apenas com agitação magnética. Quando a solução atingiu uma temperatura próxima de $33{ }^{\circ} \mathrm{C}$, o NVP foi adicionado. Por fim o ASC e $\mathrm{CuSO}_{4} \cdot 5 \mathrm{H}_{2} \mathrm{O}$ foram adicionados à solução e dissolvidos.

As concentrações dos compostos usadas para preparação das duas soluções estudadas são indicadas na Tabela 1.

Tabela 1 - Composição das duas concentrações de gel estudadas.

\begin{tabular}{|l|c|c|}
\cline { 2 - 3 } \multicolumn{1}{c|}{} & Solução 1 & Solução 2 \\
\hline Componente & Concentração & Concentração \\
\hline Gelatina 300 Bloom & $3,8 \% \mathrm{~m} / \mathrm{v}$ & $7,5 \% \mathrm{~m} / \mathrm{v}$ \\
\hline BIS & $2 \% \mathrm{~m} / \mathrm{v}$ & $4 \% \mathrm{~m} / \mathrm{v}$ \\
\hline $\mathrm{NPV}$ & $4 \% \mathrm{~m} / \mathrm{v}$ & $8 \% \mathrm{~m} / \mathrm{v}$ \\
\hline ASC & $0,007 \% \mathrm{~m} / \mathrm{v}$ & $0,007 \% \mathrm{~m} / \mathrm{v}$ \\
\hline $\mathrm{CuSO}_{4} .5 \mathrm{H}_{2} \mathrm{O}$ & $0,0008 \% \mathrm{~m} / \mathrm{v}$ & $0,0008 \% \mathrm{~m} / \mathrm{v}$ \\
\hline Água & $90,18 \% \mathrm{~m} / \mathrm{v}$ & $80,49 \% \mathrm{~m} / \mathrm{v}$ \\
\hline
\end{tabular}


As soluções foram confeccionadas em um balão de duas bocas que foi mantido em um recipiente preenchido com água (Figura 7), posicionado sobre o sistema de aquecimento e agitação magnética. Em uma boca do balão foi fixado um termômetro e a outra boca foi utilizada para inserção dos materiais. O gel foi preparado em sala com pressão e temperatura ambientes.

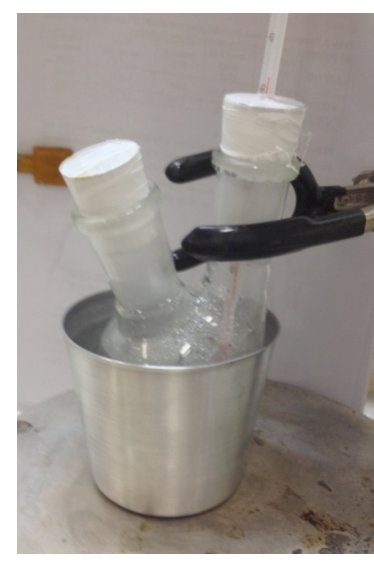

Figura 7 - Montagem experimental para confecção do gel.

Após a homogeneização, a solução foi acondicionada em cubetas de vidro padrão para espectrofotometria, de dimensões de $1 \mathrm{~cm}$ x $1 \mathrm{~cm}$ x 4,5 cm e caminho óptico de $10 \mathrm{~mm}$ conforme mostra a Figura 8. As cubetas foram fechadas usando Parafilm foil®, protegidas da luz com papel alumínio e armazenadas no refrigerador em uma temperatura em torno de $6^{\circ} \mathrm{C}$ para que a solução solidifique.

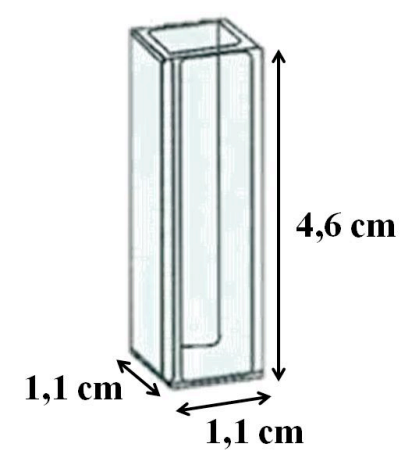

Figura 8 - Dimensões das cubetas utilizadas.

A maior dificuldade no armazenamento da solução é garantir que não se formem bolhas de ar no topo da cubeta. Conforme já descrito, o oxigênio pode inibir o processo de polimerização e consequentemente deteriorar o dosímetro gel. A influência da presença de uma bolha de ar é apresentada na Figura 9. Para mostrar o efeito do 
oxigênio no ar deixamos de forma proposital uma bolha no fundo de uma cubeta que foi irradiada. Vemos que ao redor da bolha há degradação do material, pois nesta região não ocorre $\mathrm{o}$ processo de polimerização. $\mathrm{O}$ material não adiquire coloração esbranquiçada como no restante da cubeta permanecendo transparente, conforme pode ser visualizado na Figura 9.

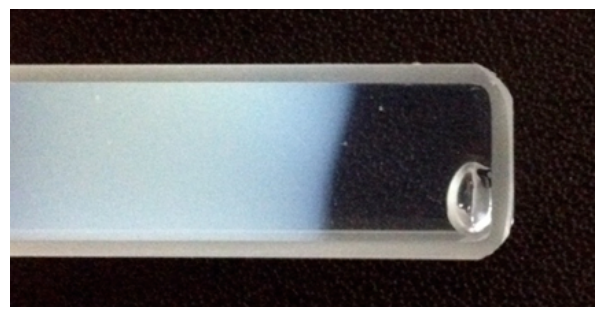

Figura 9 - Efeito de uma bolha de ar no gel VIPARnd após a irradiação.

\subsection{Objeto simulador para medidas com as cubetas}

Conforme descrito no item 2.3, o TRS 398 recomenda que as medidas de dose para feixe de fótons de alta energia em radioterapia sejam realizadas em água [22]. Porém, a inserção das cubetas em água dificultaria o controle de temperatura do gel, uma vez que a transferência de calor seria maior. Assim, as medidas com gel foram realizadas com um objeto simulador constituído de placas de água sólida e cera odontológica, conforme mostrado na Figura 10.

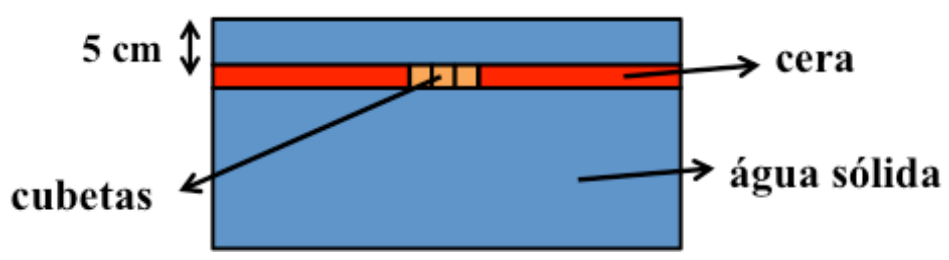

Figura 10 - Objeto simulador usado para irradiação das cubetas.

Água sólida é o nome dado a um plástico desenvolvido para dosimetria em radioterapia que possui densidade, densidade eletrônica e número atômico efetivo semelhantes ao da água. É constituído de uma mistura de poliestireno $\mathrm{CsHs}$ com $2 \%$ dióxido de titânio resultando em um material com densidade igual a $1,045 \mathrm{~g} / \mathrm{cm}^{3}$ [54]. O nome comercial destas placas é RW3 da marca Scanditronix.

A cera odontológica foi usada para preencher as laterais das cubetas. Este material também possui densidade e densidade eletrônica próximas às da água. 


\subsection{Irradiações das cubetas}

As cubetas foram acondicionadas em caixa de isopor para transporte até o local de irradiação. As irradiações foram realizadas 12h após a confecção do gel. Durante as irradiações a temperatura ambiente estava em aproximadamente $22^{\circ} \mathrm{C}$. Os dosímetros foram retirados da caixa de isopor e mantidos à temperatura ambiente até atingir equilíbrio térmico com a sala. $\mathrm{O}$ objeto simulador foi posicionado sobre a mesa do acelerador linear, com $100 \mathrm{~cm}$ de distância do foco até o centro das cubetas, em um arranjo experimental conforme apresentado na Figura 11. A dose foi calculada no centro das cubetas, na profundidade de $5 \mathrm{~cm}$ da superfície do objeto simulador e distribuída de forma homogênea ao longo do maior eixo das cubetas. As irradiações foram realizadas com o feixe de raios X usando um campo de tamanho $10 \mathrm{~cm}$ x $10 \mathrm{~cm}$.

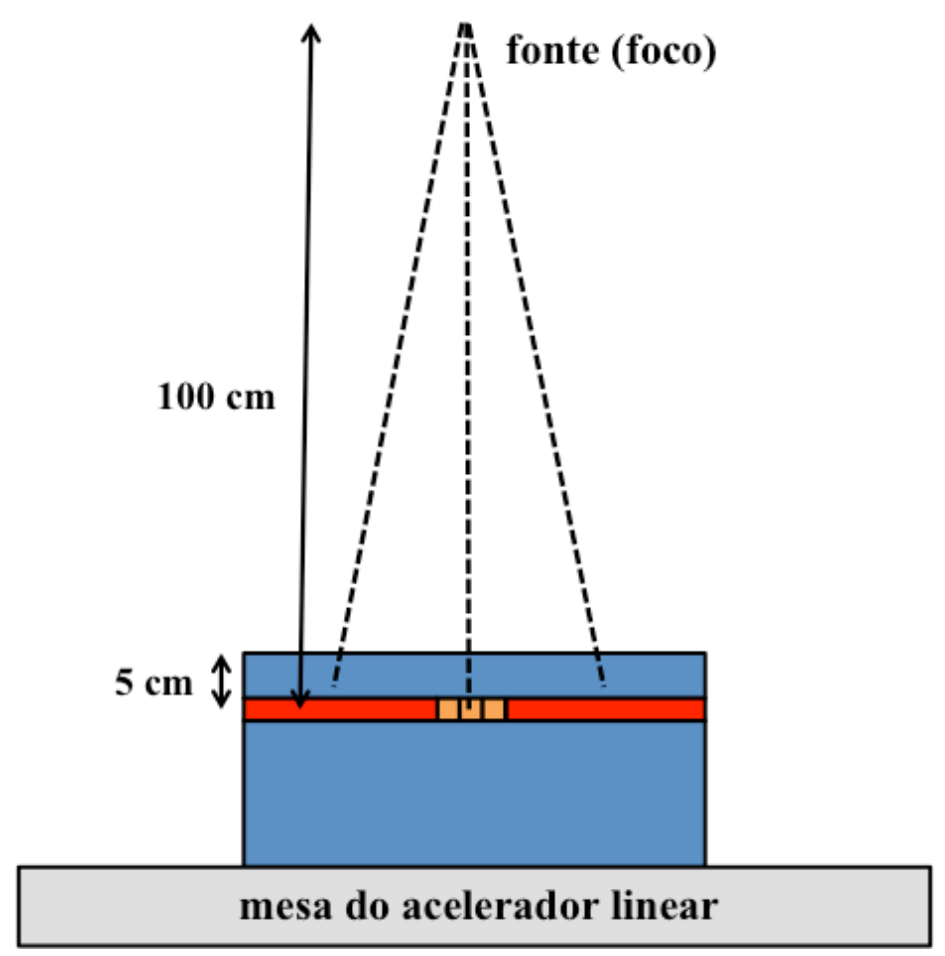

Figura 11 - Arranjo experimental para as irradiações.

O acelerador linear usado para as irradiações é da marca Varian Medical Systems modelo 21iX, instalado no Instituto de Radioterapia de Taguatinga, apesentado na Figura 12. Este equipamento produz para fins terapêuticos feixe de raios $\mathrm{X}$ de $6 \mathrm{MV}$ e feixe de elétrons de 6, 9, 12 e $15 \mathrm{MeV}$. 


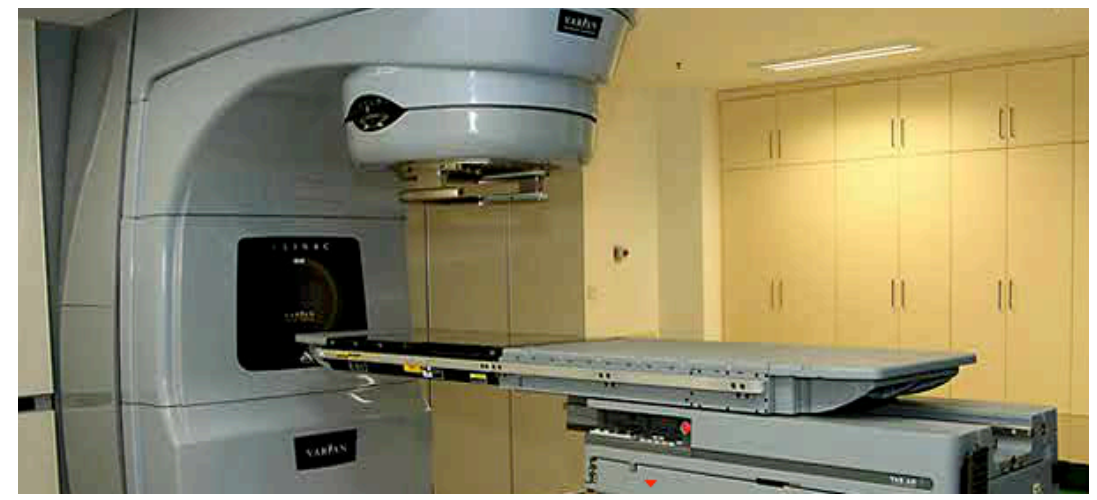

Figura 12 - Acelerador linear Varian 21iX.

Após o término das irradiações os dosímetros foram novamente armazenados e transportados até o refrigerador do laboratório, onde permaneceram até a leitura de resposta do material com a técnica de espectroscopia e análise com câmera com sensor CMOS.

\subsubsection{Curvas de resposta em função da dose}

As irradiações para determinação das curvas de resposta em função da dose foram realizadas com taxa de dose de $600 \mathrm{UM} / \mathrm{min}$.

Para cada lote um conjunto de cubetas não foi irradiada para serem usadas como cubetas de referência ( 0 Gy). As amostras com a solução 1 foram irradiadas com 1, 3, 5, 10, 15, 20 e 50 Gy e as amostras com a solução 2 foram irradiadas com 0,5, 1, 2, 3, 4, 5, $10,15,20$ e 50 Gy. A inclusão de mais valores de dose para a solução 2 deve-se ao fato da reposta linear começar com doses mais baixas.

\subsubsection{Repetitividade e Reprodutibilidade}

Para a análise de repetitividade foram analisadas 20 cubetas de um mesmo lote para cada uma das duas soluções de gel. Todas as cubetas foram irradiadas com a mesma dose. Para a solução 1 as cubetas foram irradiadas com dose de 10 Gy e para a solução 2 com a dose de 3 Gy. Para apresentação dos dados na seção 4 os valores foram normalizados pelo valor médio e o desvio padrão apresentado é o desvio padrão porcentual. 
Para a análise de reprodutibilidade foram confeccionados 20 lotes de gel de cada solução. Para a solução 1 os lotes foram irradiadas com dose de 10 Gy e para a solução 2 com a dose de 3 Gy.

Os valores de doses escolhidos correspondem a valores de dose dentro da faixa linear de resposta de dose em função da absorvância.

\subsubsection{Dependência da resposta com a taxa de dose}

Avaliou-se a variação de absorvância para as taxas de dose de 100, 200, 300, 400, 500 e $600 \mathrm{UM} / \mathrm{min}$. Para a solução 1 as cubetas foram irradiadas com dose de 10 Gy e para a solução 2 com a dose de 3 Gy.

\subsubsection{Variação da absorvância em função do tempo de leitura pós irradiação}

A análise de estabilidade temporal pós-irradiação foi estudada em função dos valores máximos de absorvância para quatro tempos após a irradiação: 24 h, 192 h e 360 h. Para a solução 1 as cubetas foram irradiadas com dose de 10 Gy e 15 Gy para a solução 2 com a dose de 1 e 3 Gy.

\subsection{Espectrofotômetro}

A espectrofotometria óptica permite medir a radiação absorvida ou transmitida em um material.

A lei de Beer-Lambert [55] define a absorvância considerando um caminho óptico de $1 \mathrm{~cm}$ é dada pela equação (16):

$$
A=-\log \frac{I}{I_{0}}
$$

sendo $I$ e $I_{0}$ as intensidades luminosas transmitidas através da amostra e através da referência respectivamente.

O espectro de absorção do gel dosímetro foi medido usando um espectrofotômetro da marca Thermo Scientific modelo Evolution 300 (Figura 13) que opera com comprimento de onda na faixa de luz visível e ultra-violeta (200 -1100 nm). Para as leituras, o conjunto de cubetas foi retirado do refrigerador e mantidos a 
temperatura ambiente até que a temperatura se estabilizasse com a temperatura da sala $\left(\sim 22^{\circ} \mathrm{C}\right)$.

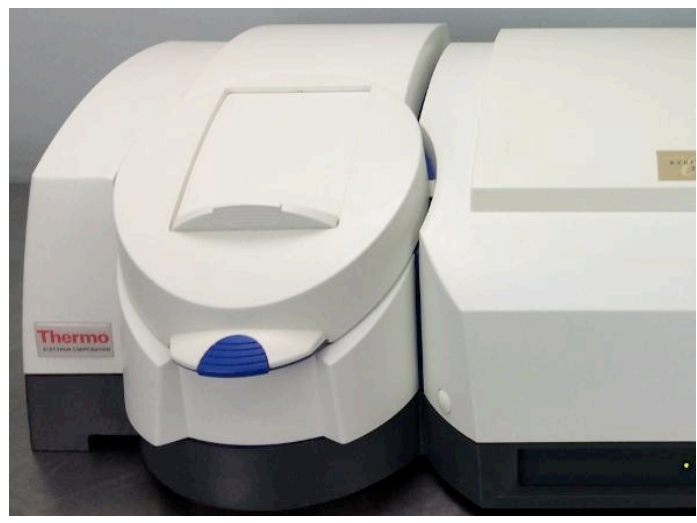

Figura 13 - Espectrofotômetro Thermo Scientific.

Para as medições das amostras, a posição de referência foi preenchida com uma cubeta vazia e a cubeta com gel foi colocada na posição de medida. Foram utilizados largura de banda de $4 \mathrm{~mm}$, velocidade de varredura de $240 \mathrm{~nm} / \mathrm{mim}$, passo de $1 \mathrm{~nm}$ e precisão de $0,1 \mathrm{~nm}$. A ordem de leitura das cubetas foi da cubeta de maior dose para a de menor dose. Para as análises iniciais do gel utilizou-se todo o intervalo disponível de comprimento de onda (200-1100 nm) e para as demais análises o intervalo de comprimento de onda usada foi de 280 a $480 \mathrm{~nm}$, conforme será mostrado na seção 4 .

Para a análise da curva de dose resposta em função do valor máximo de absorvância (Abs. Max.), o valor médio da absorvância máxima das cubetas não irradiadas $\left(A_{\max , 0}\right)$ foi subtraído do valor médio da absorvância máxima $\left(A_{\max , d}\right)$ para cada dose absorvida, conforme mostrado na equação (17):

$$
\operatorname{Abs.Max} .(d)=A_{\text {max }, d}-A_{\max , 0}
$$

A dose resposta em função da área sob a curva de absorvância foi determinada através do cálculo de integral da curva. O valor médio da área das cubetas não irradiadas foi subtraído do valor médio da área para cada dose absorvida. 


\subsection{Câmera com sensor CMOS}

O sistema de leitura utilizado é constituído por um negatoscópio clínico e uma câmera com sensor CMOS da marca Nikon Coolpix P510 posicionada em um suporte conforme mostrado na Figura 14.

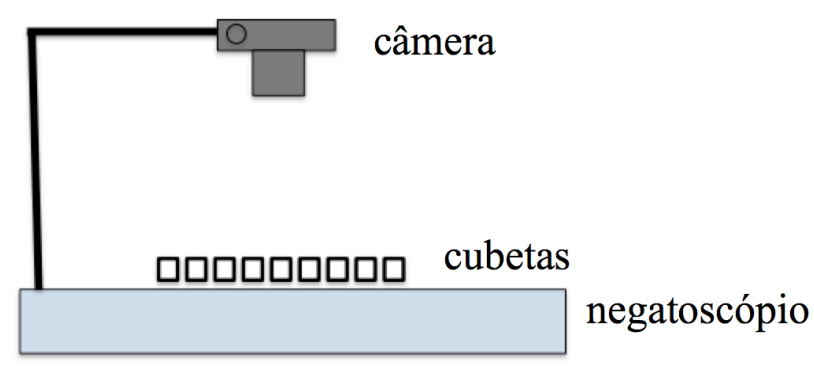

Figura 14 - Arranjo experimental do sistema de leitura com câmera.

Foram adquiridas duas imagens, a primeira da leitura de fundo, apenas com a intensidade emitida pelo negatoscópico sem as cubetas, e a segunda uma imagem das cubetas sobre o negatoscópico. As imagens foram adquiridas sem filtros, no modo manual, com a resolução máxima, em formato JPG e escala RGB (sistema de sistema de cores aditivas formado por Vermelho (Red), Verde (Green) e Azul (Blue)). As imagens foram processadas em um rotina feita no MatLab®. A primeira etapa do processamento foi aplicar o conceito de densidade óptica (D.O.) definida como:

$$
\text { D.O. }=\log \frac{I}{I_{0}},
$$

sendo I o valor médio da intensidade de pixel de uma matriz 9x9 definida a partir do centro da cubeta e $\mathrm{I}_{0}$ o valor médio da intensidade de pixel de uma matriz 9x9 da imagem de leitura de fundo na mesma posição de cada cubeta.

O processamento foi realizado para cada componente da escala RGB conforme será mostrado na seção 4.

Optou-se por trabalhar com o valor médio de uma matriz de 9x9 para análise de um maior número de pixels, como forma de diminuir a influência de ruídos aleatórios na imagem.

Para as leituras, o conjunto de cubetas foi retirado do refrigerador e mantidos à temperatura ambiente até que a mesma estabilizasse com a temperatura da sala $\left(\sim 22^{\circ} \mathrm{C}\right)$. 


\subsection{Medidas de perfil para campos pequenos}

Para análise do perfil de campos de raios $\mathrm{X}$ foi confeccionada uma caixa de acrílico conforme mostrado na Figura 15.

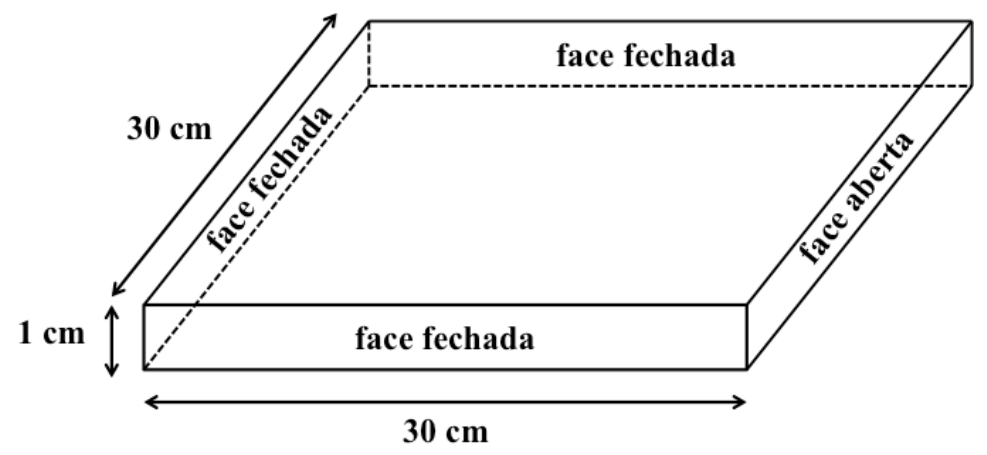

Figura 15 - Caixa de acrílico usada para medidas de perfil.

A caixa foi preenchida com gel VIPARnd com as concentrações da solução 2, a face aberta foi fechada usando Parafilm foil@ ${ }^{\circledR}$. Papel alumínio foi usado para cobrir a caixa e esta foi armazenada no refrigerador em uma temperatura em torno de $6^{\circ} \mathrm{C}$ para a solução solidificar. Para as irradiações, a temperatura do gel estava em aproximadamente $22^{\circ} \mathrm{C}$, mesma temperatura da sala. A caixa preenchida com gel foi posicionada entre placas de água sólida, com o centro da caixa ficando em uma profundidade de 1,5 cm conforme a configuração apresentada na Figura 16.

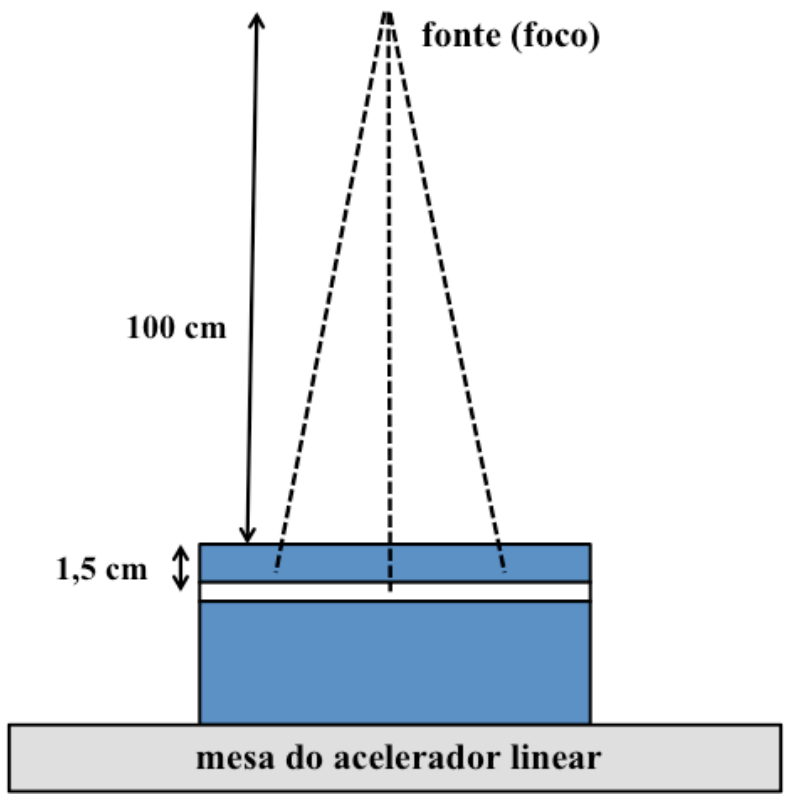

Figura 16 - Arranjo experimental para medidas de perfil. 
Foram realizadas medidas para um campo quadrado de $5 \mathrm{~cm}$ x $5 \mathrm{~cm}$ e campos circulares de cones de $7,5 \mathrm{~mm}, 10 \mathrm{~mm}, 15 \mathrm{~mm}, 20 \mathrm{~mm}$ e $30 \mathrm{~mm}$ usados para radiocirurgia. Para o campo quadrado utilizou-se $500 \mathrm{UM}$ e para os circulares 1000 UM.

Após a irradiação a caixa de acrílico foi posicionada sob o sistema de leitura com negatoscópio e câmera com sensor CMOS da mesma forma como apresentado na Figura 14. Foram adquiridas duas imagens, uma apenas com a intensidade emitida pelo negatoscópico, e outra imagem da caixa sobre o negatoscópico. As imagens foram adquiridas sem filtros, no modo manual, com a resolução máxima, em formato JPG e escala RGB. Para o processamento das imagens utilizou-se uma rotina no MatLab®, que calcula a densidade óptica usado apenas a componente azul das imagens. Uma linha no centro do campo foi selecionada, os valores destas linha foram suavizados e normalizados de 0 a $100 \%$.

As medidas de perfil obtidas a partir da análise das imagens foram comparadas aos dados de perfil do sistema de planejamento (SP) para os campos estudados. Para comparação do perfil para o campo de $5 \mathrm{~cm} \times 5 \mathrm{~cm}$, os dados foram extraídos do sistema de planejamento Eclipse ${ }^{\circledR}$ versão 11. Os dados dos campos circulares com cones de radiocirugia foram retirados do sistema de planejamento iPlan ${ }^{\circledR}$ versão 4.5.

Para avaliação da concordância entre as medições feitas com gel e os dados do SP foi utilizado o índice Gamma $(\Gamma)$. Este método incialmente proposto por Low et al. em 1998 avalia a concordância entre a distribuição de dose medida e a distribuição de dose prevista ou calculada, quantificando o quão perto estas distribuições estão em um determinado ponto. Para isso, leva-se em consideração um critério de aceitação para a diferença percentual entre os valores de dose a uma dada distância entre os pontos de dose [7]. O índice Gamma (Г) é definido pela equação (19):

$$
\Gamma=\sqrt{\frac{r^{2}}{\Delta d_{M}^{2}}+\frac{\delta^{2}}{\Delta D_{M}^{2}}},
$$

onde $r$ é a distância espacial entre os pontos de dose analisados (posição do ponto de medida menos a posição do ponto calculado), $\delta$ é a diferença entre os valores de dose nesses pontos (dose medida menos a dose calculada), $\Delta \mathrm{d}_{\mathrm{M}}$ é o critério de distância aceito e $\Delta \mathrm{D}_{\mathrm{M}} \mathrm{o}$ critério de diferença porcentual de dose aceito. 
Por definição, quando o valor calculado de $\Gamma$ é menor do que 1 , significa que as doses analisadas concordam entre si considerando os critérios de aceitação. Os critérios de aceitação sugeridos por Low et al. para a distância $\left(\Delta \mathrm{d}_{\mathrm{M}}\right)$ e porcentagem de dose $\left(\Delta \mathrm{D}_{M}\right)$ são $3 \mathrm{~mm}$ e $3 \%$, respectivamente. Assim, usando $\Delta \mathrm{d}_{M}=3 \mathrm{~mm}$ e $\Delta \mathrm{D}_{\mathrm{M}}=3 \%$, quando o valor de calculado para o índice $\Gamma$ de um dado ponto for menor do que 1 , significa que os valores de dose concordam entre si, aceitando uma variação de $3 \%$ de diferença de dose em um distância de $3 \mathrm{~mm}$.

\subsection{Medidas de PDP}

Para uma medida preliminar da PDP de um campo $10 \mathrm{~cm} \times 10 \mathrm{~cm}$ um tubo de ensaio foi preenchido com gel VIPARnd com as concentrações da solução 2. O tubo foi posicionado no objeto simulador usado para calibração do feixes de radiação, um tanque de acrílico preenchido com água, conforme mostrado na Figura 17.

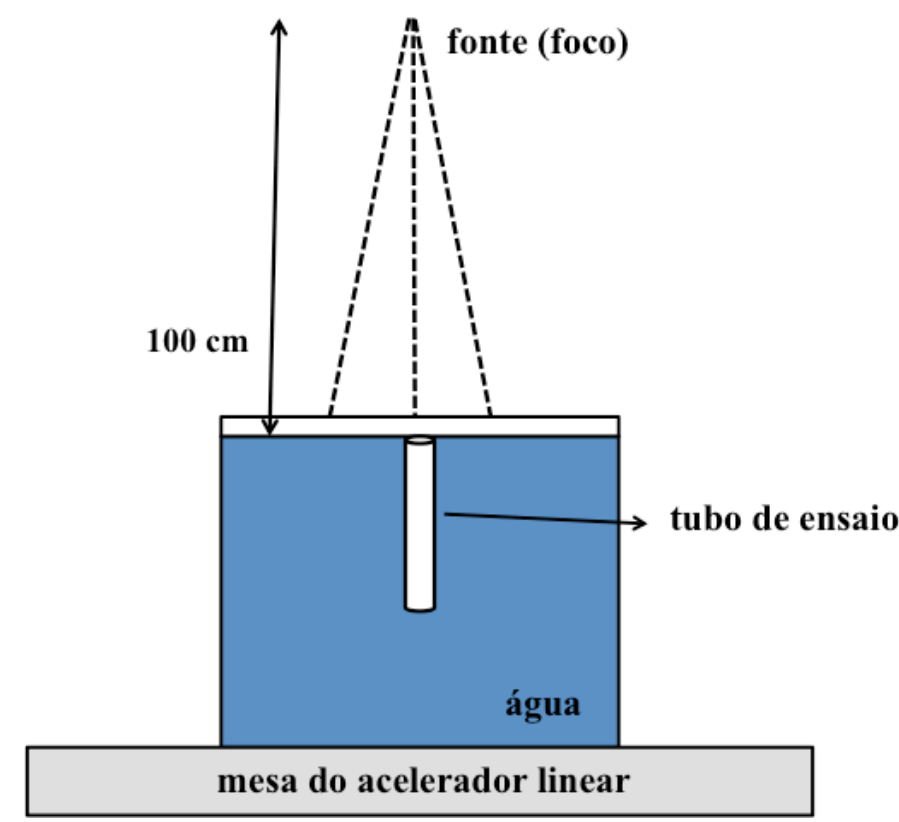

Figura 17 - Arranjo experimental para medida de PDP.

Foi utilizado 1000 UM para a irradiação e a temperatura do gel foi mantida igual temperatura da água e da sala, que no momento da irradiação era de aproximadamente $22^{\circ} \mathrm{C}$.

Após a irradiação o tubo de ensaio foi posicionado sob o sistema de leitura com negatoscópio e câmera com sensor CMOS. Duas imagens foram adquiridas, uma com a 
intensidade emitida pelo negatoscópico, e outra imagem do tubo de ensaio sobre o negatoscópico. As imagens foram adquiridas sem filtros, no modo manual, com a resolução máxima, em formato JPG e escala RGB. Para o processamento das imagens utilizou-se a mesma rotina no MatLab® usada para as medidas dos perfis. Uma linha no centro do tubo de ensaio foi selecionado, os valores desta linha foram normalizados em dose porcentual.

\subsection{Medidas com fonte de Braquiterapia}

Um frasco de vidro preenchido com gel VIPARnd com as concentrações da solução 2 foi usado para as medidas com fonte de braquiterapia. Este frasco foi fechado com um rolha de borracha, na qual foi introduzido um pedaço de sonda de soro. Isto foi feito para que a fonte de braquiterapia pudesse ser inserida no interior do frasco, conforme apresentado na Figura 18.

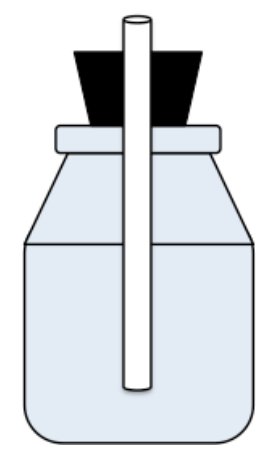

Figura 18 - Frasco de vidro usado para as medidas com a fonte de braquiterapia.

Utilizou-se uma fonte de Irídio 192 de um equipamento Gammamed Plus de braquiterapia de alta taxa de dose instalado no Instituto de Radioterapia de Taguatinga. Foram programadas duas paradas de tempo nominal de 60 s. Na Figura 19 é mostrada a distribuição de dose prevista pelo sistema de planejamento Brachyvision ${ }^{\circledR}$ versão 11 para o plano com as duas paradas programadas. O frasco foi retirado da geladeira, esperando que a temperatura do gel se estabilizasse com a temperatura da sala de braquiterapia $\left(\sim 22^{\circ} \mathrm{C}\right)$ para realização da irradiação. 


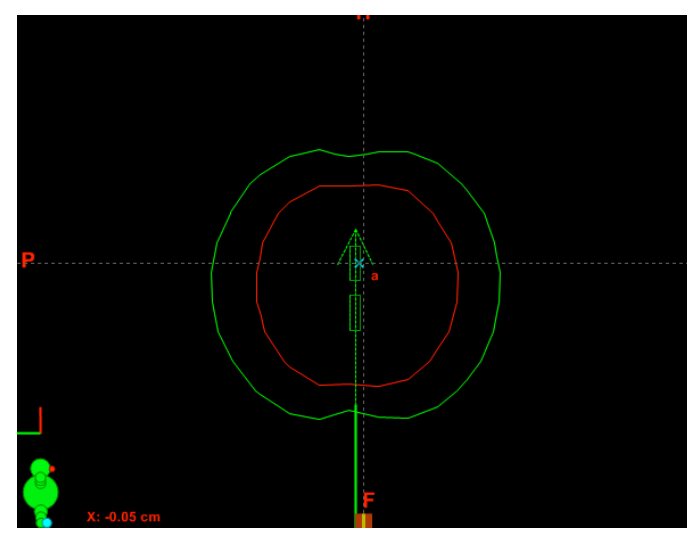

Figura 19 - Distribuição de dose prevista para o plano de braquiterapia.

Após a irradiação foi adquirida uma imagem com câmera com sensor CMOS do frasco de vidro sob o negatoscópio. A imagem foi adquirida sem filtros, no modo manual, com a resolução máxima, em formato JPG e escala RGB. Para o processamento das imagem utilizou-se uma rotina no MatLab®. A dose foi analisada entre as duas paradas programadas, em uma linha perpendicular ao deslocamento da fonte. Os valores obtidos foram normalizados em dose porcentual.

\subsection{Medidas com Tomografia Computadorizada}

Foram adquidos cortes axiais em um equipamento de Tomografia Computadorizada de um lote de cubetas com VIPARnd com as concentrações da solução 2. As imagens foram adquiridas em formato Dicom com espessura de corte de $1 \mathrm{~mm}, 120 \mathrm{kV}$ e $250 \mathrm{~mA}$. O equipamento utilizado foi um Toshiba Activion 16 instalado na Radiologia Anchieta.

As imagens adquiridas foram processadas em uma rotina no MatLab® que calcula o valor médio do número TC de um voxel 9x9x9 definido a partir do centro de cada cubeta. 


\section{Capítulo 4 Resultados e Discussões}




\section{RESULTADOS E DISCUSSÕES}

A interação da radiação ionizante com o gel VIPARnd ocasiona mudança em sua coloração. O gel não irradiado é transparente e à medida que a dose de absorção aumenta mais esbranquiçado fica o material. Essa característica de alteração de cor, fornece contraste óptico, validando as análises ópticas para avaliação de dose neste material. Na Figura 20 é apresentado conjuntos de cubetas das soluções 1 e 2 com diferentes valores de dose.

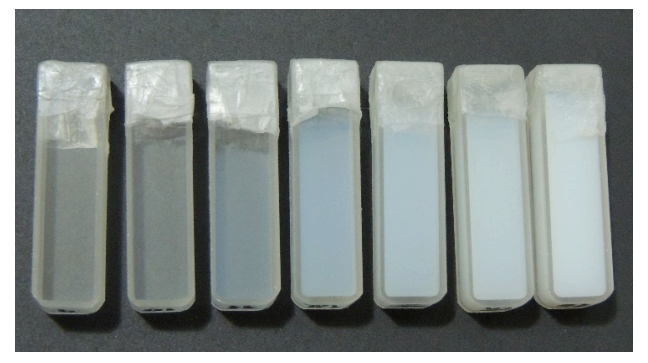

(a)

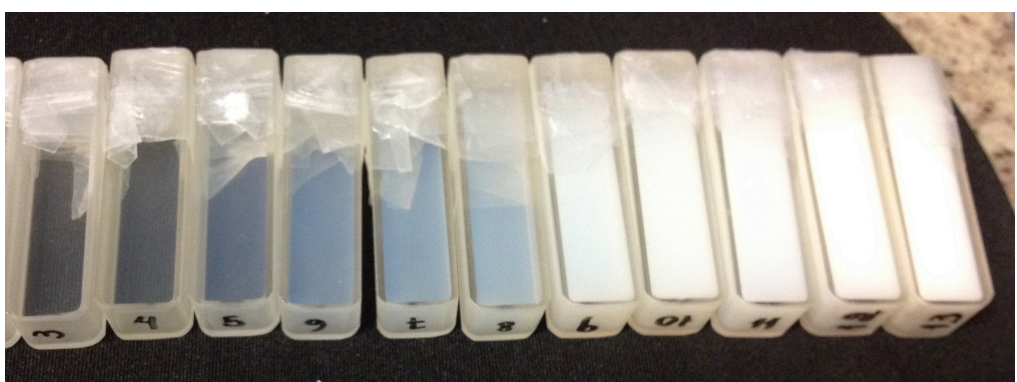

(b)

Figura 20 - Alteração de cor no dosímetro VIPARnd com as concentrações da solução 1 devido a irradiação com raios X de $6 \mathrm{MV}$. (a) Gel com as concentrações da solução 1, da esquerda para direita doses de $0,3,5,10,15,20$ e $50 \mathrm{~Gy}$. (b) Gel com as concentrações da solução 2 , da esquerda para direita doses de $0,0,5,1,2,3,4,5,10,15,20$ e $50 \mathrm{~Gy}$.

Como as concentrações de NVP e BIS são diferentes para as duas soluções estudadas, a resposta em função da dose é diferente. Para a solução 2, que possui uma concentração maior destes componentes notou-se uma sensibilização maior com a dose, com doses de 0,5 Gy já é possível notar alteração visível na coloração. Dentro do intervalo de resposta para um mesmo valor de dose, o gel feito a partir da solução 2 apresenta maior opacidade que o da solução 1 . 


\subsection{Espectro de Absorção}

Os espectros de absorvância na região visível e ultra violeta do gel VIPARnd para as soluções 1 e 2 são apresentados na Figura 21. Para a solução 1 é mostrado a absorvância para uma amostra não irradiada (com dose de 0 Gy) e para uma amostra irradiada com dose de 10 Gy (Figura 21 (a)). As curvas de absorvância apresentadas para a solução 2 são para as doses de 0 Gy (referência) e 3 Gy (Figura 21 (b)). As doses mostradas para cada solução foram escolhidas dentro dos valores estudados. Optou-se por mostrar apenas a dose de referência (0 Gy) e uma dose intermediária no intervalo de reposta, apenas para evidenciar as alterações no espectro de absorção causadas pela interação do gel com a radiação ionizante.

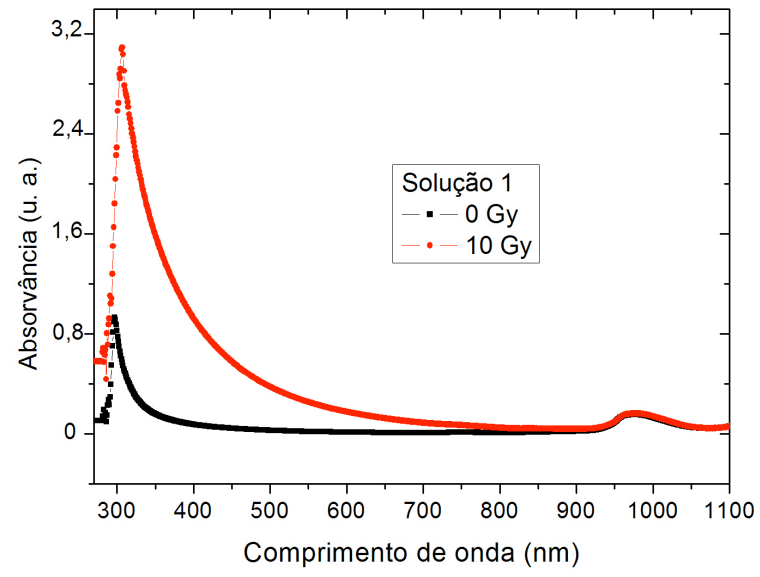

(a)

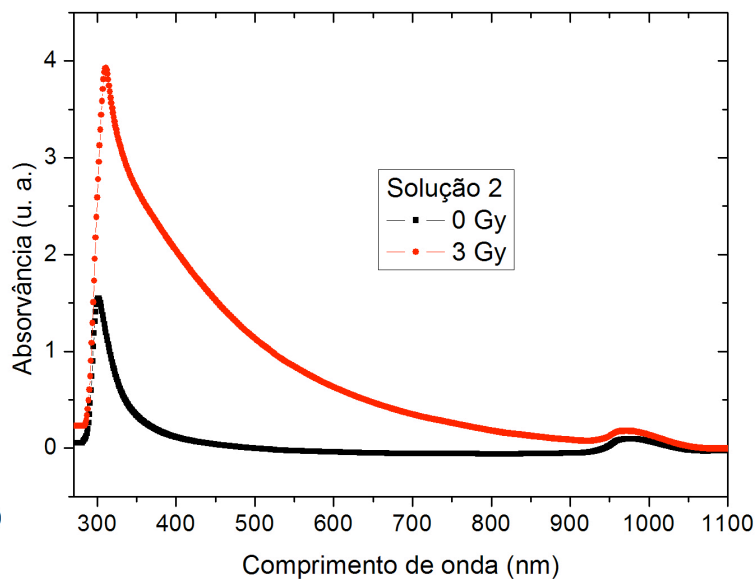

(b)

Figura 21 - Espectro de absorvância na região visível e ultra violeta para o gel VIPARnd. (a) Solução 1 com doses de 0 Gy e 10 Gy, (b) Solução 2 com doses de 0 Gy e 3 Gy.

Podemos observar que o gel VIPARnd apresenta duas bandas de absorção, uma mais intensa entre 300 a $310 \mathrm{~nm}$ e outra menos intensa entre 950 e $1050 \mathrm{~nm}$. A segunda banda apresenta aumento discreto na absorção com a irradiação do material. Já a máxima absorvância, visualizada no intervalo de 300 a 310 nm é bastante alterada com a irradiação do gel, o que sugere que esta é a banda de absorção mais importante para a avaliação de resposta deste dosímetro. De qualquer forma a absorvância para todos os comprimentos de onda estudados aumenta com a irradiação do material, característica da opacidade gerada com a radiação. Há também um deslocamento da banda para comprimento de ondas maiores com o aumento da dose absorvida. 
Desta forma para as análises de resposta em função do máximo de absorvância, assim como as análises em função da área sob a curva de absorção foi utilizado o intervalo mais sensível. Na Figura 22 são apresentadas as curvas de absorção de um lote da solução 1 para as doses de 0 a 50 Gy no intervalo de 280 a $480 \mathrm{~nm}$.

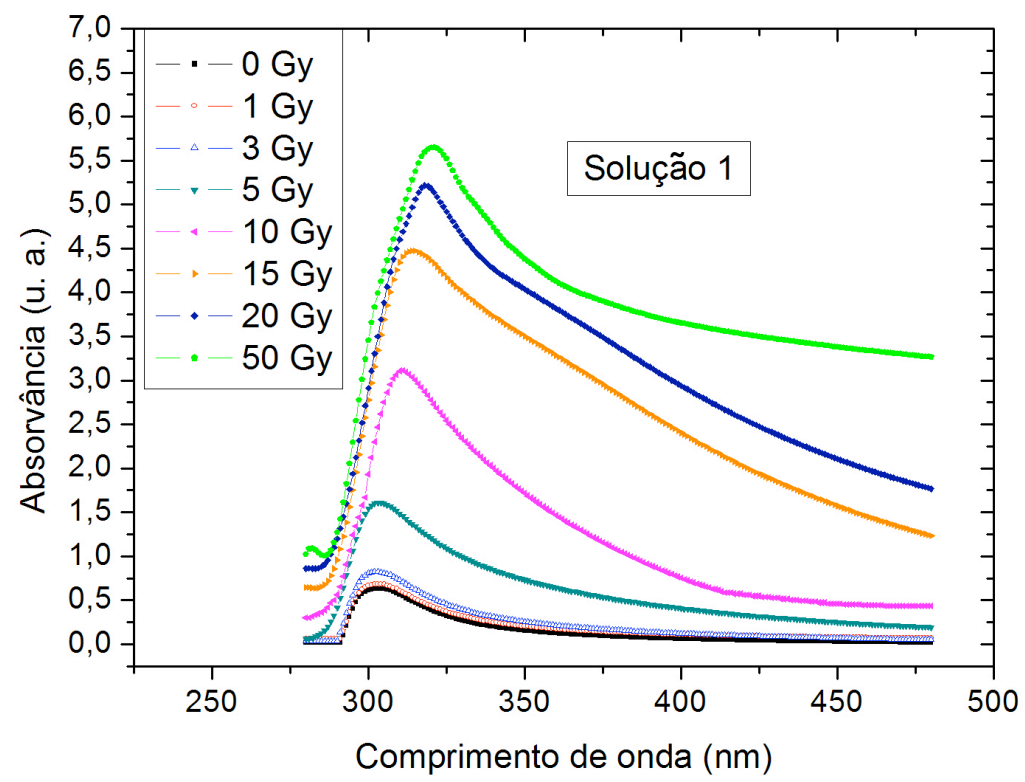

Figura 22 - Espectro de absorvância para o intervalo de 280 a $480 \mathrm{~nm}$ para a solução 1 de gel VIPARnd para as doses de 0 Gy, 1 Gy, 3 Gy, 5 Gy, 10 Gy, 15 Gy, 20 Gy e 50 Gy.

O espectro de absorção da solução 1 apresentado na Figura 22, mostra que para as doses de 0 Gy e 1 Gy a variação nas curvas são pequenas, praticamente dentro das incertezas estatísticas das medidas. Já para os demais valores de dose é possível visualizar diferenças na absorvância das amostras.

A Figura 23 mostra o espectro de absorvância para um lote da solução 2, no mesmo intervalo de comprimento de onda e para as mesmas doses apresentadas para a solução 1. É possível notar que os valores de absorvância para a solução 2 são maiores que os obtidos para a solução 1, isso para um mesmo valor de dose. Por exemplo, para as amostras irradiadas com 10 Gy, observa-se para a solução 2 um valor de máximo de absorção de 5,1 e para a solução 1 um valor de 3,1. 


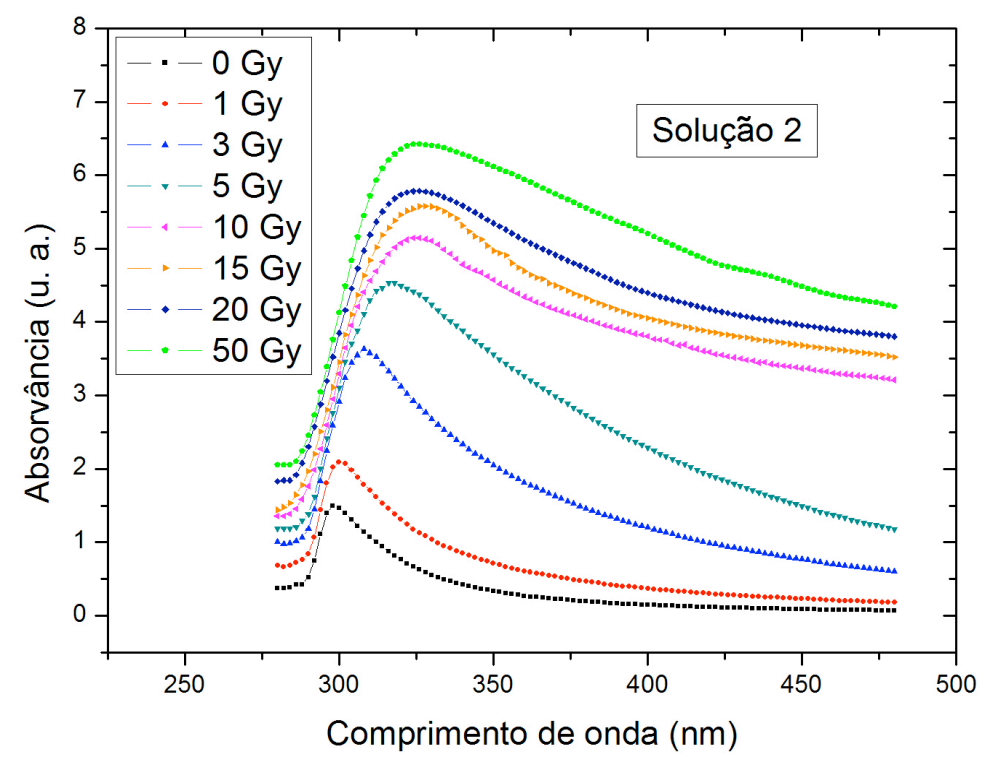

Figura 23 - Espectro de absorvância para o intervalo de 280 a $480 \mathrm{~nm}$ para a solução 2 de gel VIPARnd para as doses de 0 Gy, 1 Gy, 3 Gy, 5 Gy, 10 Gy, 15 Gy, 20 Gy e 50 Gy.

De acordo com os dados apresentados na Figura 23 pode ser observado que a solução 2 apresenta maior variação na absorção para doses entre 0 Gy e 5 Gy, é possível diferenciar os espectros de 0 Gy e 1 Gy. Assim optou-se por estudar também as doses de 0,5 Gy, 2 Gy e 4 Gy, conforme pode ser visualizado na Figura 24.

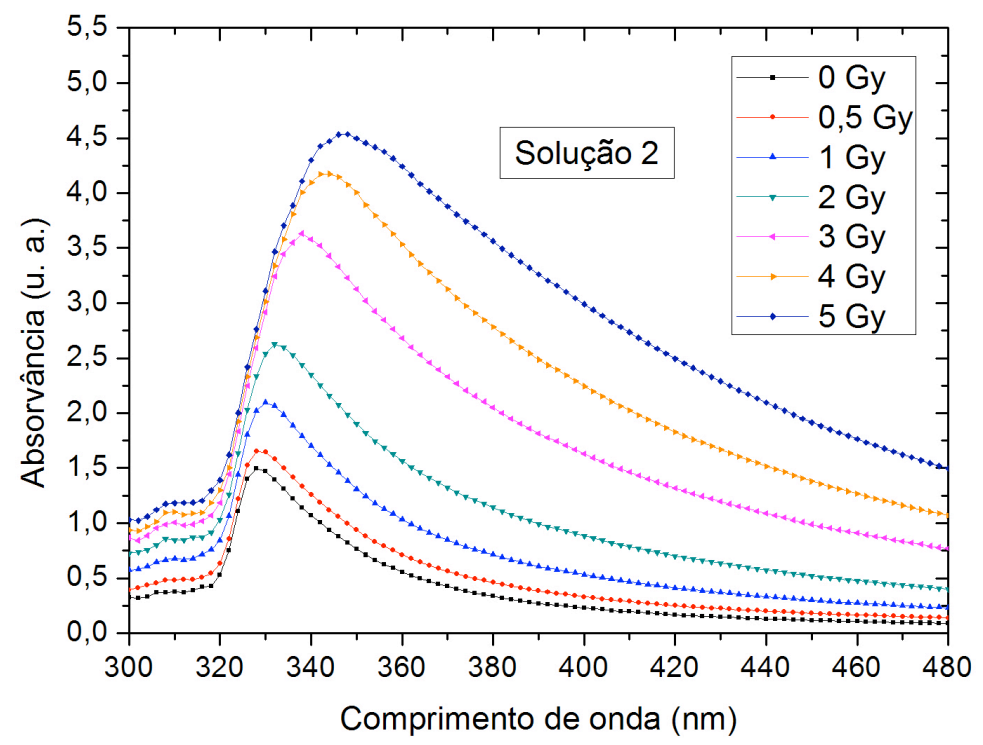

Figura 24 - Espectro de absorvância para o intervalo de 280 a $480 \mathrm{~nm}$ para a solução 2 de gel VIPARnd para as doses de 0 Gy, 1 Gy, 2 Gy, 3 Gy, 4 Gy e 5 Gy. 


\subsection{Dose resposta em função do máximo de absorção}

As curvas de dose resposta em função do valor de absorvância máxima para o VIPARnd com as duas concentrações estudadas podem ser visualizadas nas Figuras 25 e 26 . Os valores apresentados correspondem ao valor médio do máximo de absorção para 10 lotes de gel.

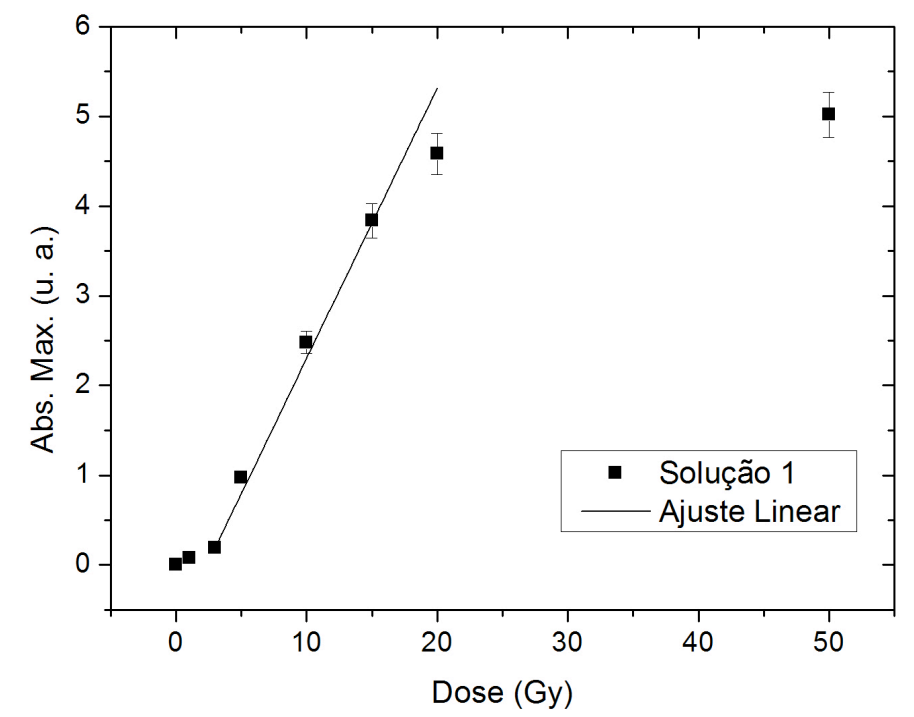

Figura 25 - Curva de dose resposta em função do máximo de absorção para a solução 1 de VIPARnd.

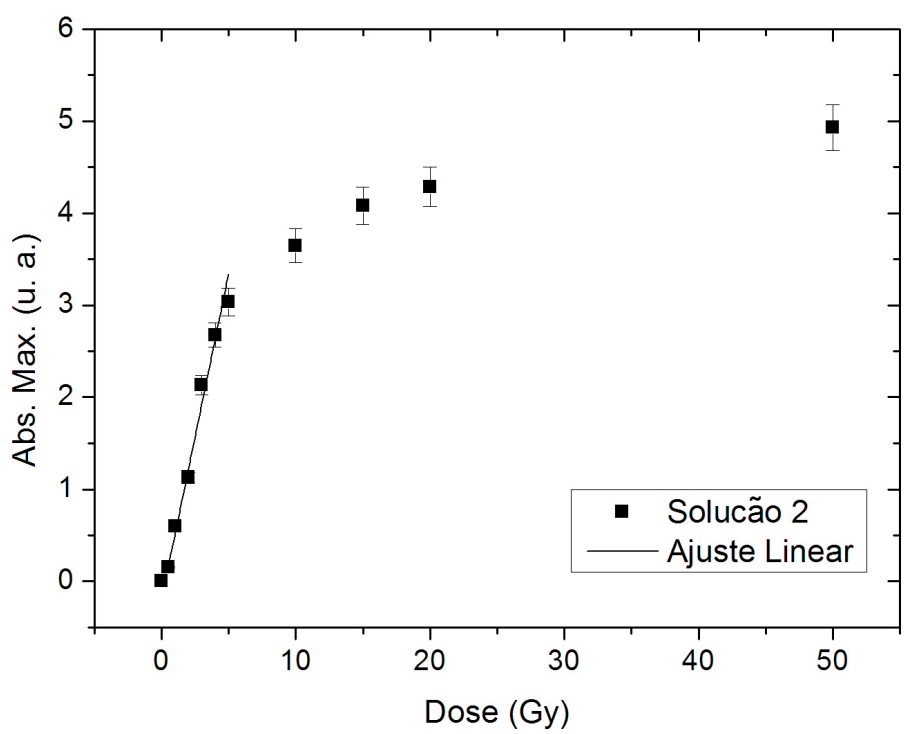

Figura 26 - Curva de dose resposta em função do máximo de absorção para a solução 2 de VIPARnd. 
Pode ser observado um comportamento sigmoidal para as curvas de resposta, característica dos dosímetros químicos. Existe uma região inicial em que as interações são tão pequenas a ponto de não sensibilizarem o dosímetro. Em seguida temos uma região praticamente linear, principal área de interesse, afinal nesta região consegue-se diferenciar bem os diferentes valores de dose absorvida. Por fim, o gel começa a apresentar saturação, num limiar de dose em que todas as interações possíveis já aconteceram e não há mais como acontecer alterações detectáveis no material. A região linear da curva é área útil de utilização do dosímetro.

Para o feixe de raios $\mathrm{X}$ de $6 \mathrm{MV}$ a curva dose resposta foi ajustada como uma reta para leituras de doses de 3 a 20 Gy para a solução 1 e para o intervalo de 1 a 5 Gy para a solução 2. Os coeficientes angulares e lineares das retas estão apresentados na Tabela 2.

Tabela 2 - Coeficientes do ajuste linear da curva dose resposta em função do máximo de absorvância.

\begin{tabular}{|l|c|c|}
\cline { 2 - 3 } \multicolumn{1}{c|}{} & Solução 1 & Solução 2 \\
\hline Coeficiente Linear & $-0,79 \pm 0,03$ & $-0,19 \pm 0,01$ \\
\hline Coeficiente Angular & $0,33 \pm 0,01$ & $0,71 \pm 0,02$ \\
\hline
\end{tabular}

O coeficiente angular da curva de dose resposta pode ser usado para quantificar a sensibilidade do dosímetro, uma vez que apresenta a inclinação da curva. Quanto maior a inclinação, menores os intervalos de dose detectáveis e consequentemente maior a sensibilidade.

Apesar da região útil para as duas soluções serem diferentes, os valores mostrados na Tabela 2 mostram que o ajuste linear para solução 2 apresenta um coeficiente angular maior.

\subsection{Repetitividade e Reprodutibilidade}

As Figuras 27 e 28 apresentam a absorvância máxima relativa de cubetas de um mesmo lote para a solução 1 e 2 , respectivamente. As linhas pontilhadas nos gráficos das Figuras 27 e 28 representam o valor de um desvio padrão $( \pm 1 \sigma)$. 


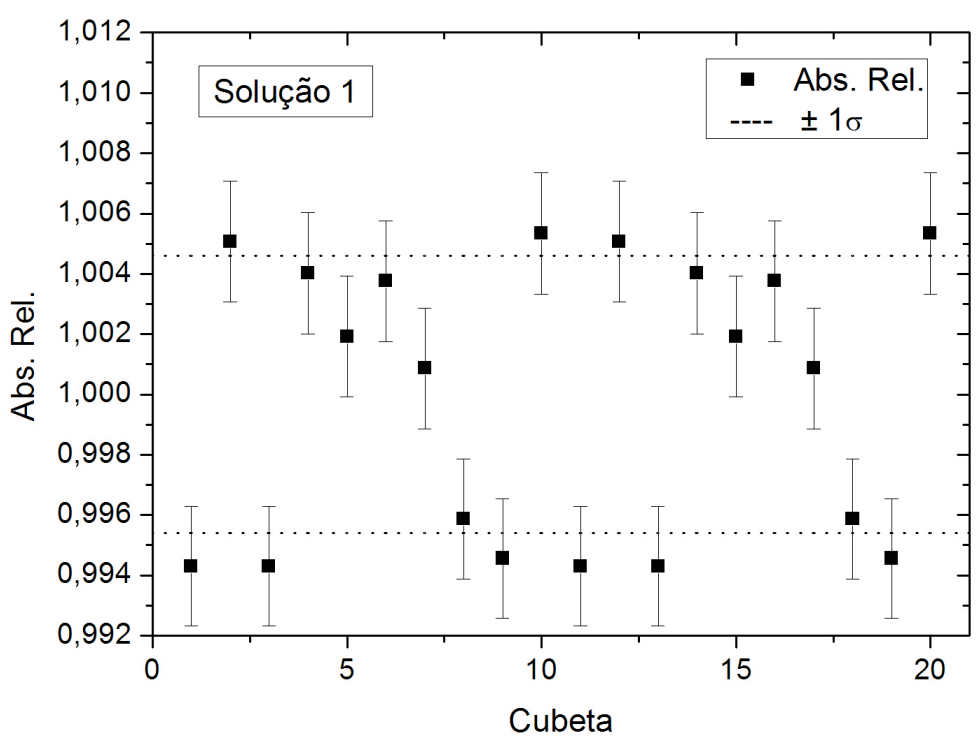

Figura 27 - Absorvância Relativa (valor absoluto dividido pelo valor médio) para cubetas irradiadas de um mesmo lote da solução 1 .

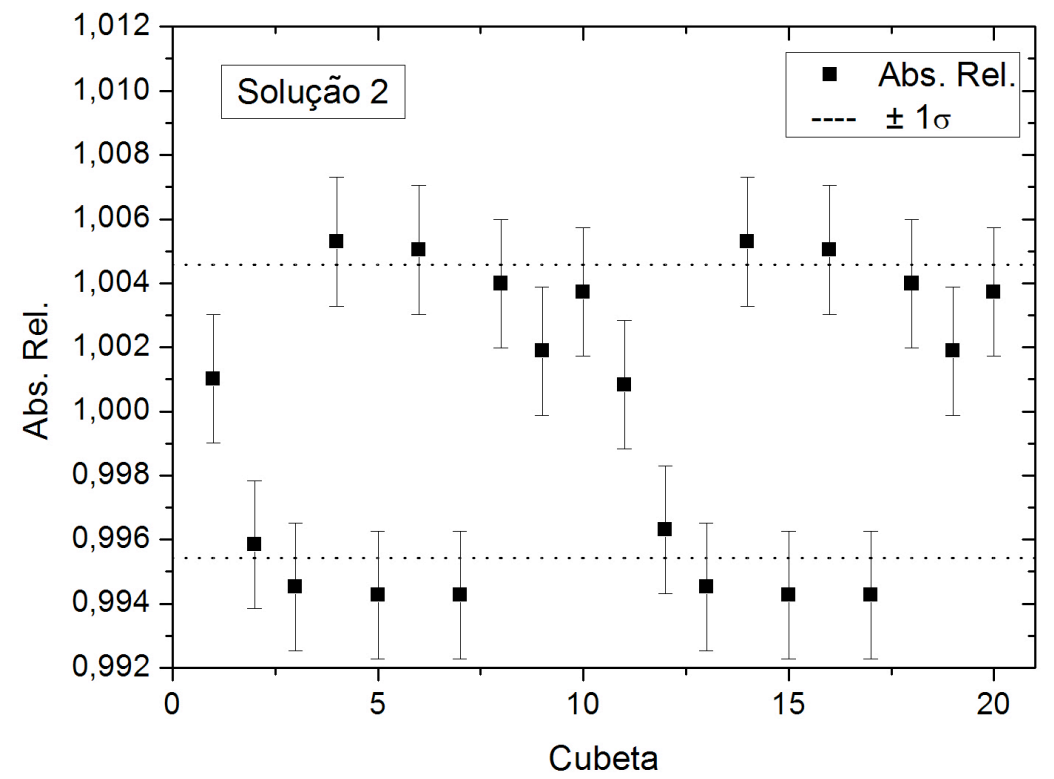

Figura 28 - Absorvância Relativa (valor absoluto dividido pelo valor médio) para cubetas de um mesmo lote da solução 2 .

Com os resultados para cubetas irradiadas de um mesmo lote, para estudo da repetitividade do gel, foi observado um desvio padrão de $\pm 0,5 \%$ para as duas soluções analisadas. 
A absorvância máxima relativa de diferentes lotes são apresentadas nas Figuras 29 e 30.

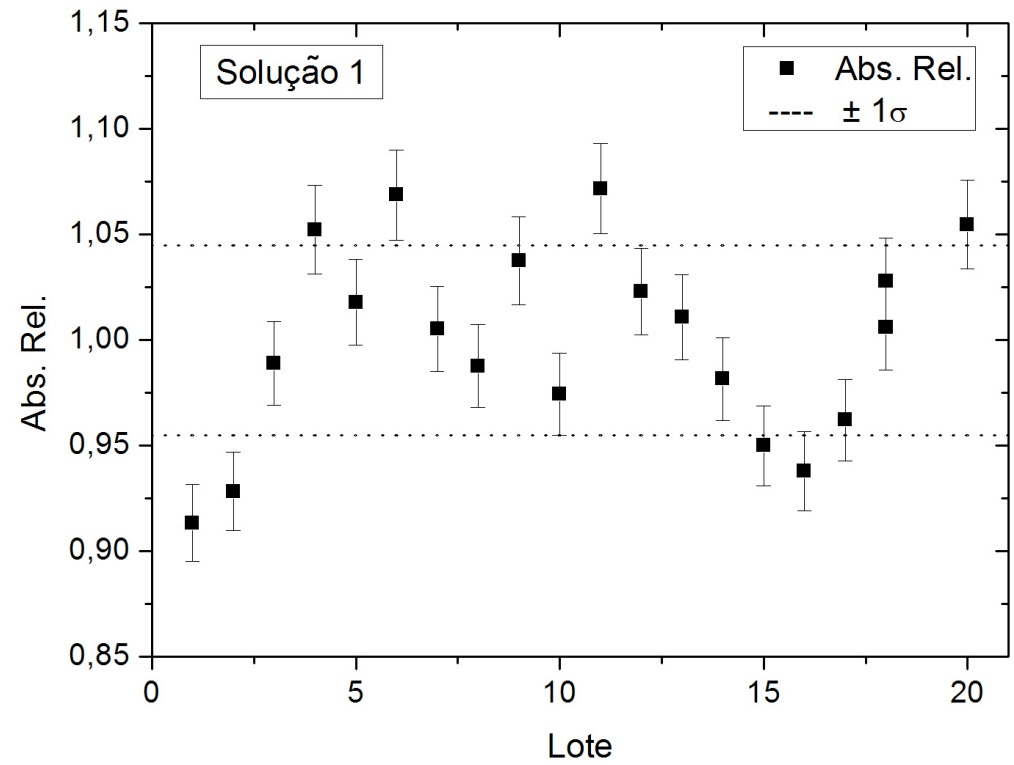

Figura 29 - Absorvância Relativa (valor absoluto dividido pelo valor médio) para 20 lotes da solução 1 .

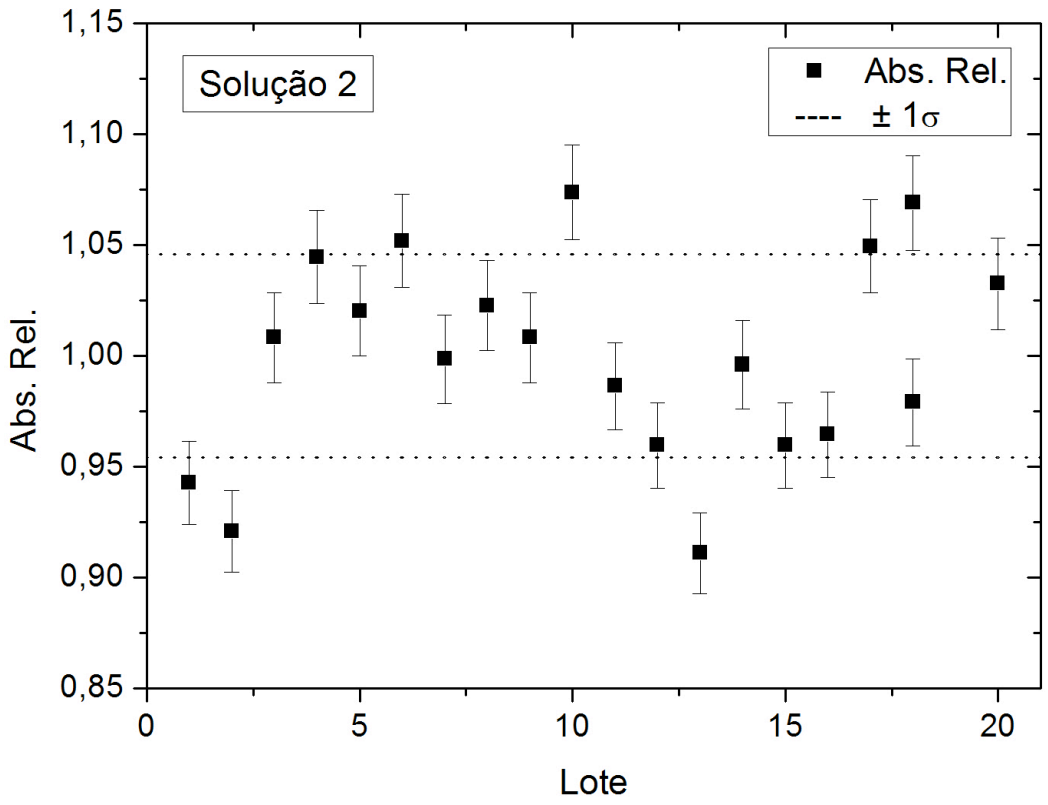

Figura 30 - Absorvância Relativa (valor absoluto dividido pelo valor médio) para 20 lotes da solução 2 .

De acordo com os resultados para cubetas irradiadas de um mesmo lote, para análise da reprodutibilidade do gel, foi obtido um desvio padrão de $\pm 5 \%$ para ambas as soluções analisadas. 


\subsection{Dependência da resposta com a taxa de dose}

A Figura 31 apresenta a absorvância máxima relativa para cubetas de um mesmo lote da solução 1 irradiadas com 10 Gy para os 6 valores de taxa de dose disponíveis no acelerador linear para o feixe de raios $\mathrm{X}$ de $6 \mathrm{MV}$.

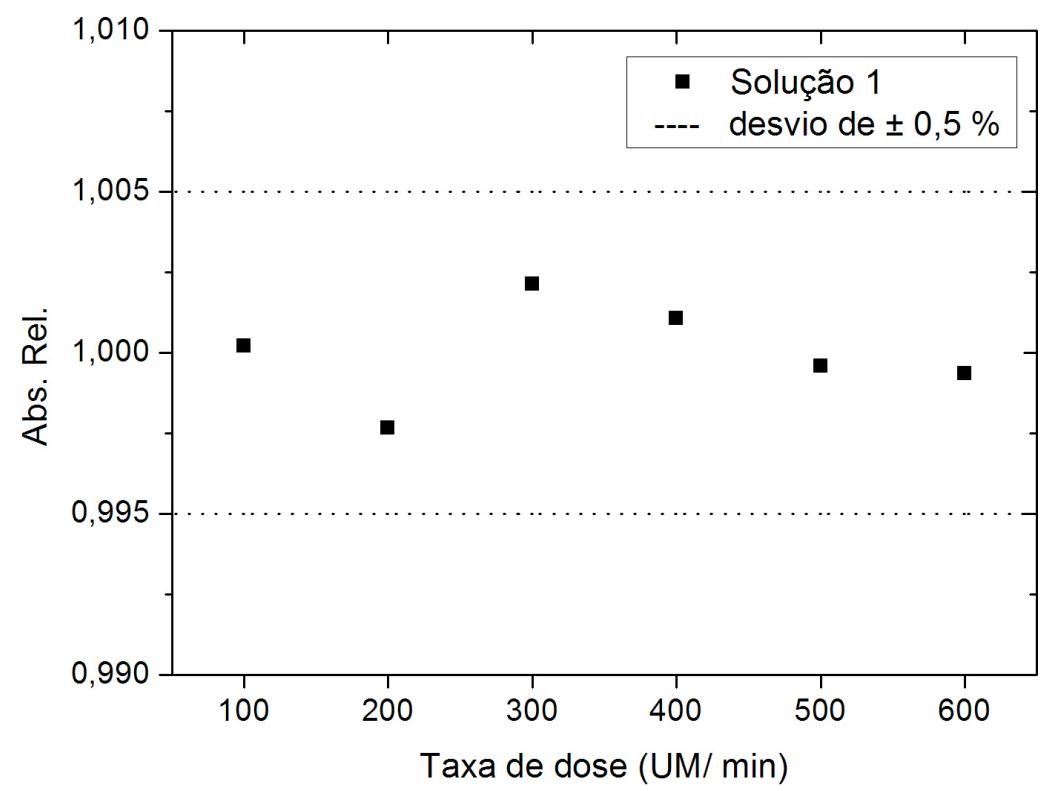

Figura 31 - Absorvância Relativa (valor absoluto dividido pelo valor médio) em função da taxa de dose para a solução 1 .

Na Figuras 32 é apresentada a absorvância máxima relativa para cubetas de um mesmo lote da solução 2, irradidas com 3 Gy para os 6 valores de taxa de dose.

Foram inseridas nos gráficos das Figuras 31 e 32 linhas pontilhadas representando a variação de $\pm 0,5 \%$ esperada para cubetas de um mesmo lote, resultado obtido através da análise de repetitividade. Pode-se afirmar através do dados obtidos que a dependência com a taxa de dose para o dosímetro gel não é significativa. 


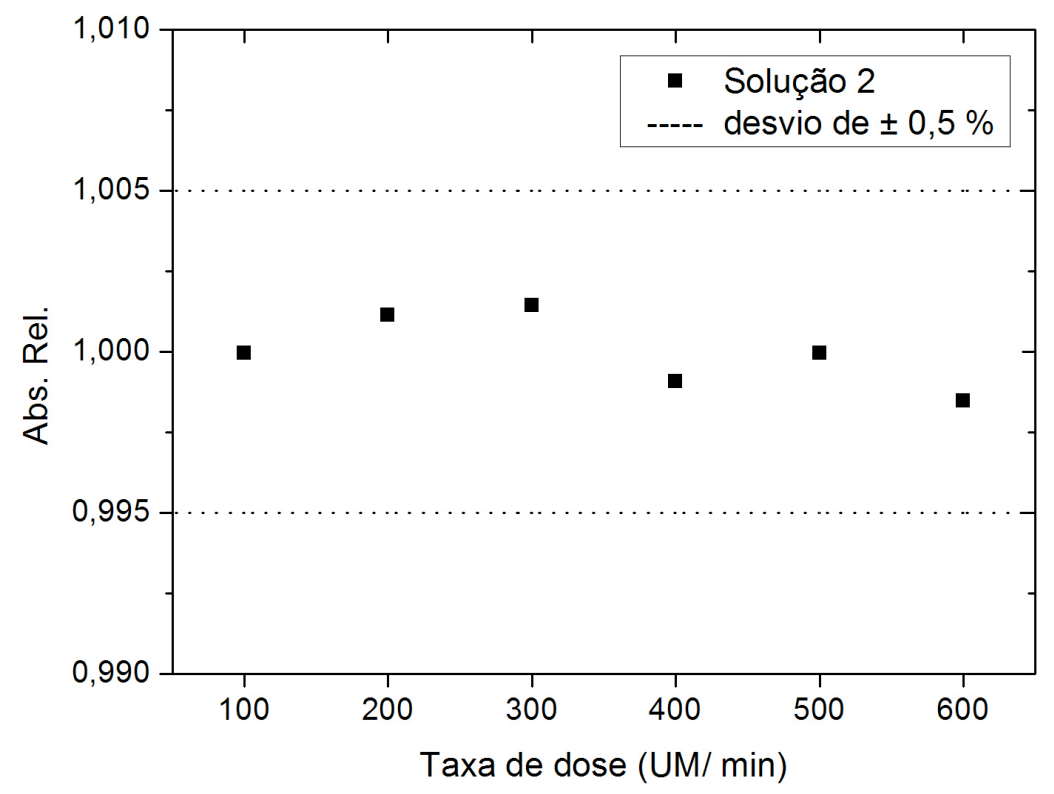

Figura 32 - Absorvância Relativa (valor absoluto dividido pelo valor médio) em função da taxa de dose para a solução 2 .

\subsection{Variação da absorvância em função do tempo de leitura pós irradiação}

Nas Figuras 33 e 34 são apresentados valores de máximo de absorvância para diferentes tempos de leituras após a irradiação das amostras.

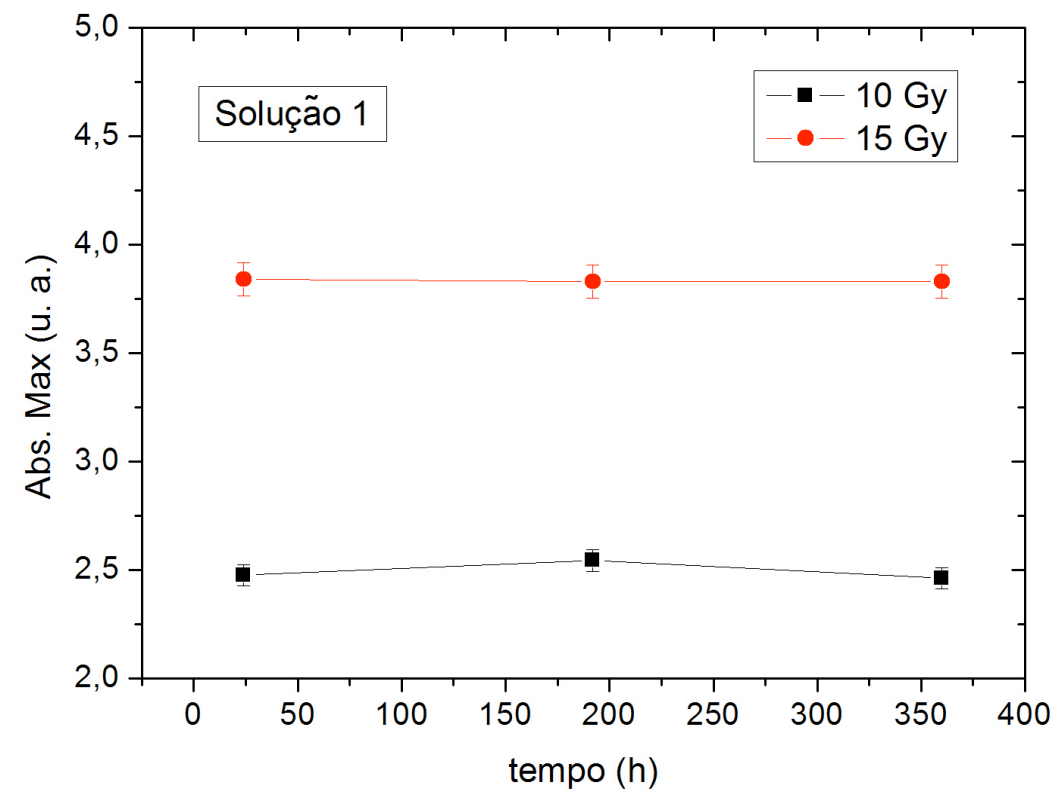

Figura 33 - Valores de absorvância máxima para diferentes tempos após a irradiação para a solução 1 . 


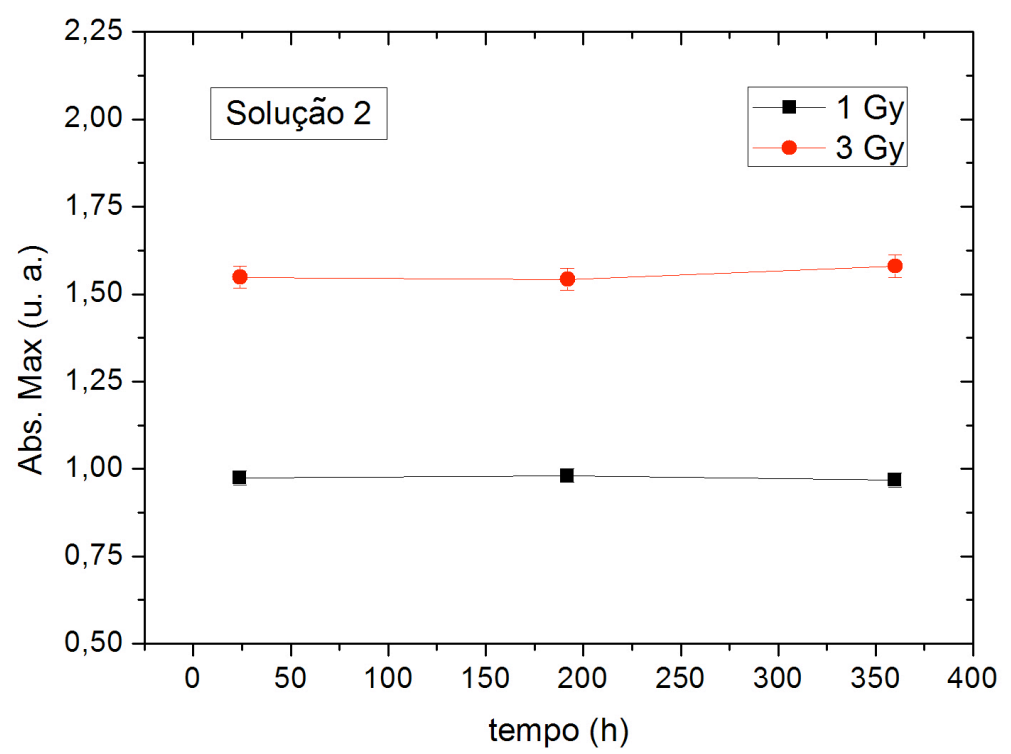

Figura 34 - Valores de absorvância máxima para diferentes tempos após a irradiação para a solução 2 .

Pode-se observar através dos dados apresentados que para o intervalo de tempo de $24 \mathrm{~h}$ a 360 h a resposta do dosímetro permaneceu estável para ambas as soluções.

\subsection{Dose resposta em função da área sobre a curva de absorção}

As curvas de dose resposta em função da área sob a curva de absorvância para o VIPARnd com as duas concentrações estudadas são apresentdas nas Figuras 35 e 36. Os valores apresentados correspondem ao valor médio da área sob a curva de absorção para 10 lotes de gel. Foi realizado ajuste linear para a faixa útil em cada curva de dose resposta. 


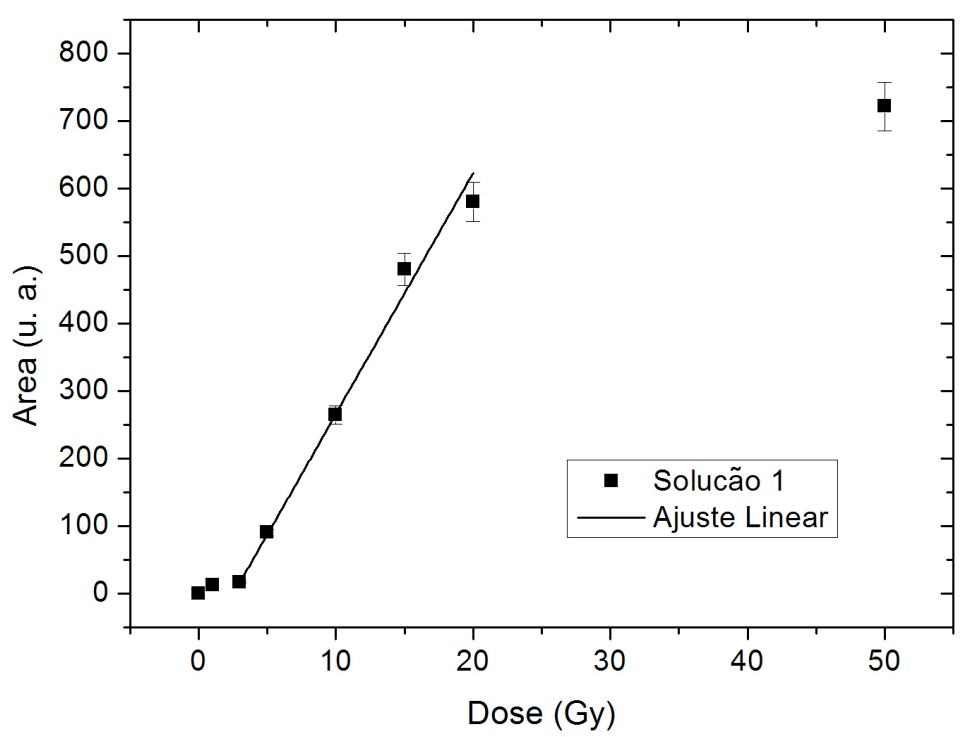

Figura 35 - Curva de dose resposta em função da área sob a curva de absorção para a solução 1 de VIPARnd.

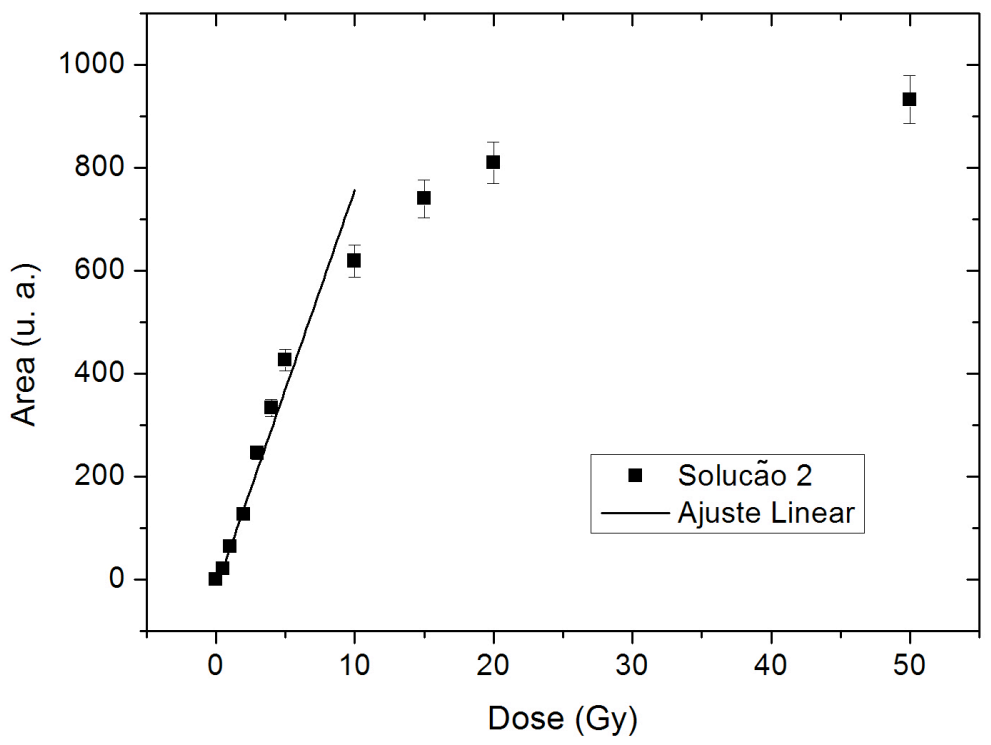

Figura 36 - Curva de dose resposta em função da área sob a curva de absorção para a solução 2 de VIPARnd.

Para a solução 1 a curva dose resposta foi ajustada como uma reta para leituras de doses de 3 a 20 Gy e para a solução 2 o ajuste foi feito na faixa de 1 a 10 Gy. Os coeficientes angular e linear das retas são apresentados na Tabela 3. 
Tabela 3 - Coeficientes do ajuste linear da curva dose resposta em função da área da curva de absorvância.

\begin{tabular}{|l|l|l|}
\cline { 2 - 3 } \multicolumn{1}{c|}{} & Solução 1 & Solução 2 \\
\hline Coeficiente Linear & $-90,7 \pm 3,1$ & $-18,2 \pm 1,5$ \\
\hline Coeficiente Angular & $35,7 \pm 1,0$ & $77,5 \pm 1,9$ \\
\hline
\end{tabular}

Nota-se através dos dados apresentados na Tabela 3, que a solução 2 apresenta ajuste com um coeficiente angular maior, representando maior sensibilidade.

\subsection{Dose resposta em função das imagens com câmera de sensor CMOS}

Na Figura 37 é apresentada a curva de D.O. em função da dose para as componentes vermelha, verde e azul da matriz RGB da análise feita para a solução 1 . Os valores dos gráficos correspondem a D.O. média de 5 lotes.

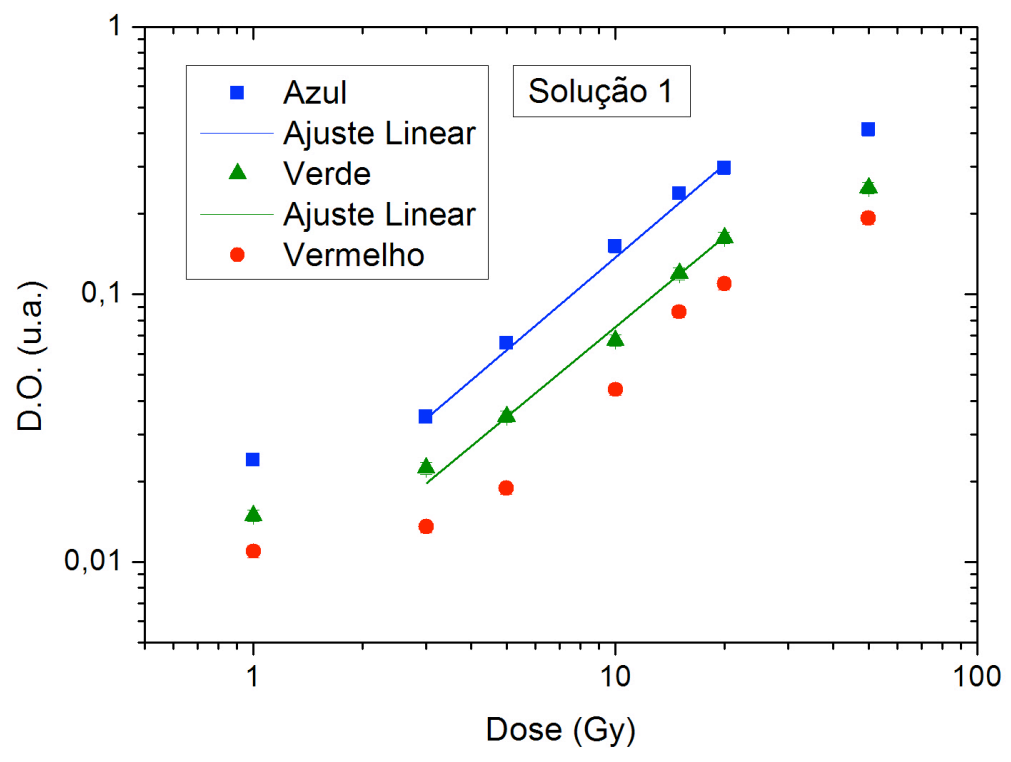

Figura 37 - Curva de densidade óptica em função da dose para cada componente da matriz RGB da solução 1 .

A Figura 38 mostra a curva de D.O. média de 5 lotes em função da dose da solução 2 para cada componete da matriz RGB. 


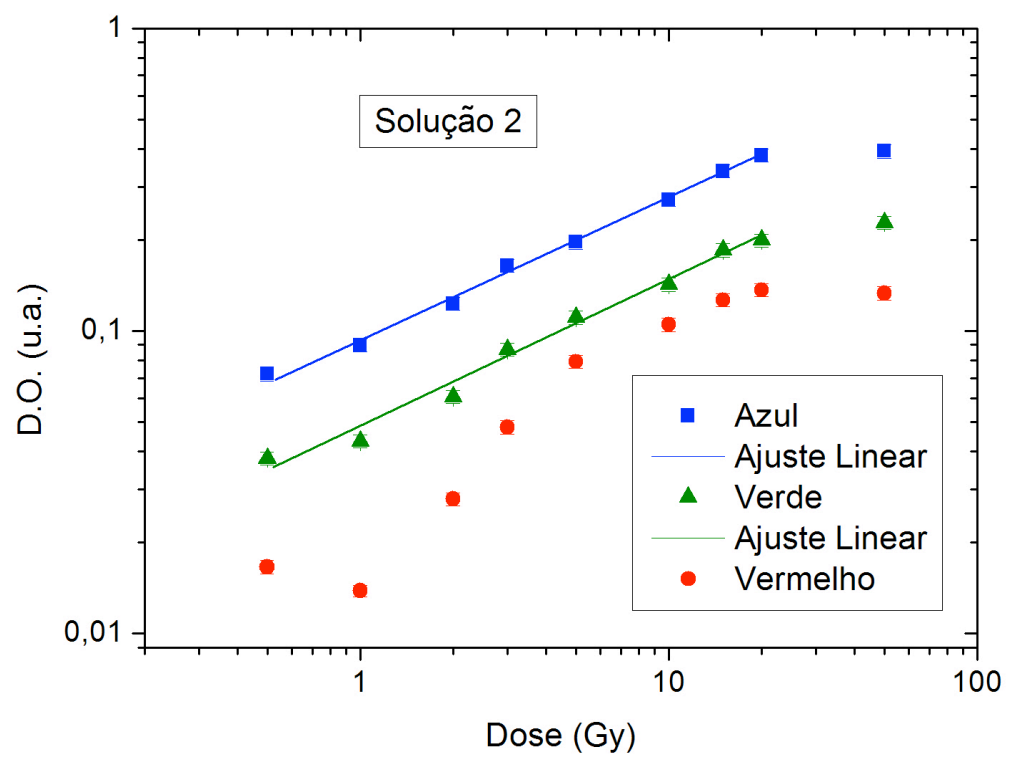

Figura 38 - Curva de densidade óptica em função da dose para cada componente da matriz RGB da solução 2.

A análise inicial do espectro de absorção foi importante para a compreensão de qual componente da matriz RGB mostraria maior resposta com a dose. As Figuras 37 e 38 mostram que a componente com maior resposta é a azul para ambas as soluções. Trata-se da cor mais próxima ao comprimento de absorção máxima do gel. A componente verde vem em seguida e por último com menor resposta temos a componente vermelha.

Optou-se por realizar ajuste linear para as componentes azul e verde. Para a solução 1 o ajuste foi feito para o intervalo de dose de 3 a 20 Gy e para solução 2 para as doses de 0,5 a 20 Gy. Para esse método de análise de resposta do dosímetro as faixas lineares para as duas soluções ficam mais próximas. A solução 1 continua não apresentando sensibilidade para doses inferiores a 3 Gy, porém para a solução 2 com esta metodologia foi possível extender a faixa útil até 20 Gy.

$\mathrm{Na}$ Tabela 4 são apresentados os coeficientes dos ajustes lineares realizados nos gráficos das Figuras 37 e 38. 
Tabela 4 - Coeficientes do ajuste linear da curva dose resposta em função das componentes Azul e Verde das imagens com câmera com sensor CMOS.

\begin{tabular}{|c|l|c|c|}
\cline { 3 - 4 } \multicolumn{2}{c|}{} & Solução 1 & Solução 2 \\
\hline \multirow{2}{*}{ Azul } & Coeficiente Linear & $-0,013 \pm 0,002$ & $0,081 \pm 0,004$ \\
\cline { 2 - 4 } & Coeficiente Angular & $0,016 \pm 0,001$ & $0,019 \pm 0,001$ \\
\hline \multirow{2}{*}{ Verde } & Coeficiente Linear & $-0,001 \pm 0,001$ & $0,037 \pm 0,002$ \\
\cline { 2 - 4 } & Coeficiente Angular & $0,007 \pm 0,001$ & $0,011 \pm 0,001$ \\
\hline
\end{tabular}

Os coeficientes angulares dos ajustes para as curvas obtidas para a solução 2 são discretamente maiores. Dentre as demais metodologias apresentadas, observa-se que em especial para a solução 2 este foi o método que apresentou maior faixa útil de detecção de dose, com boa sensibilidade.

\subsection{Medidas de perfil para campos pequenos}

Na Figura 39 é apresentada a imagem obtida para a análise do perfil do campo quadrado de $5 \mathrm{~cm} \times 5 \mathrm{~cm}$ e com campos circulares com os cones de 7,5 mm, $10 \mathrm{~mm}$, $15 \mathrm{~mm}, 20 \mathrm{~mm}$ e $30 \mathrm{~mm}$.

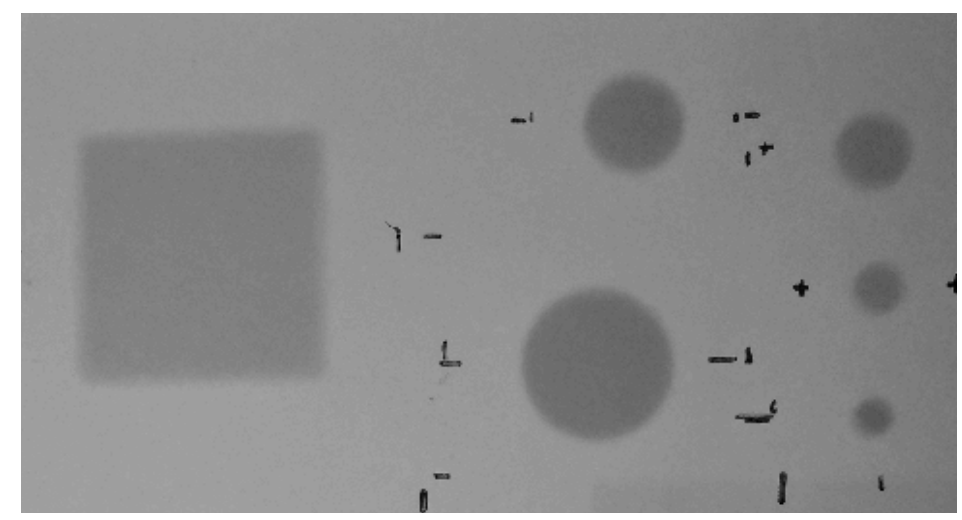

Figura 39 - Imagem usada para medida dos perfis do campo quadrado de $5 \mathrm{~cm}$ x $5 \mathrm{~cm}$ (esquerda) e dos circulares com cones (direita).

As medidas com gel VIPARnd obtidas com a análise das imagens e os dados extraídos do sistema de planejamento (SP) para os campos estudados são apresentados na Figura 40. As linhas pontilhadas em preto nos gráficos representam o valor de índice Gamma e as vermelhas foram inseridas sobre o valor igual a 1, para auxiliar na 
identificação das regiões em que os pontos falharam na análise Gamma $(\Gamma>1)$.
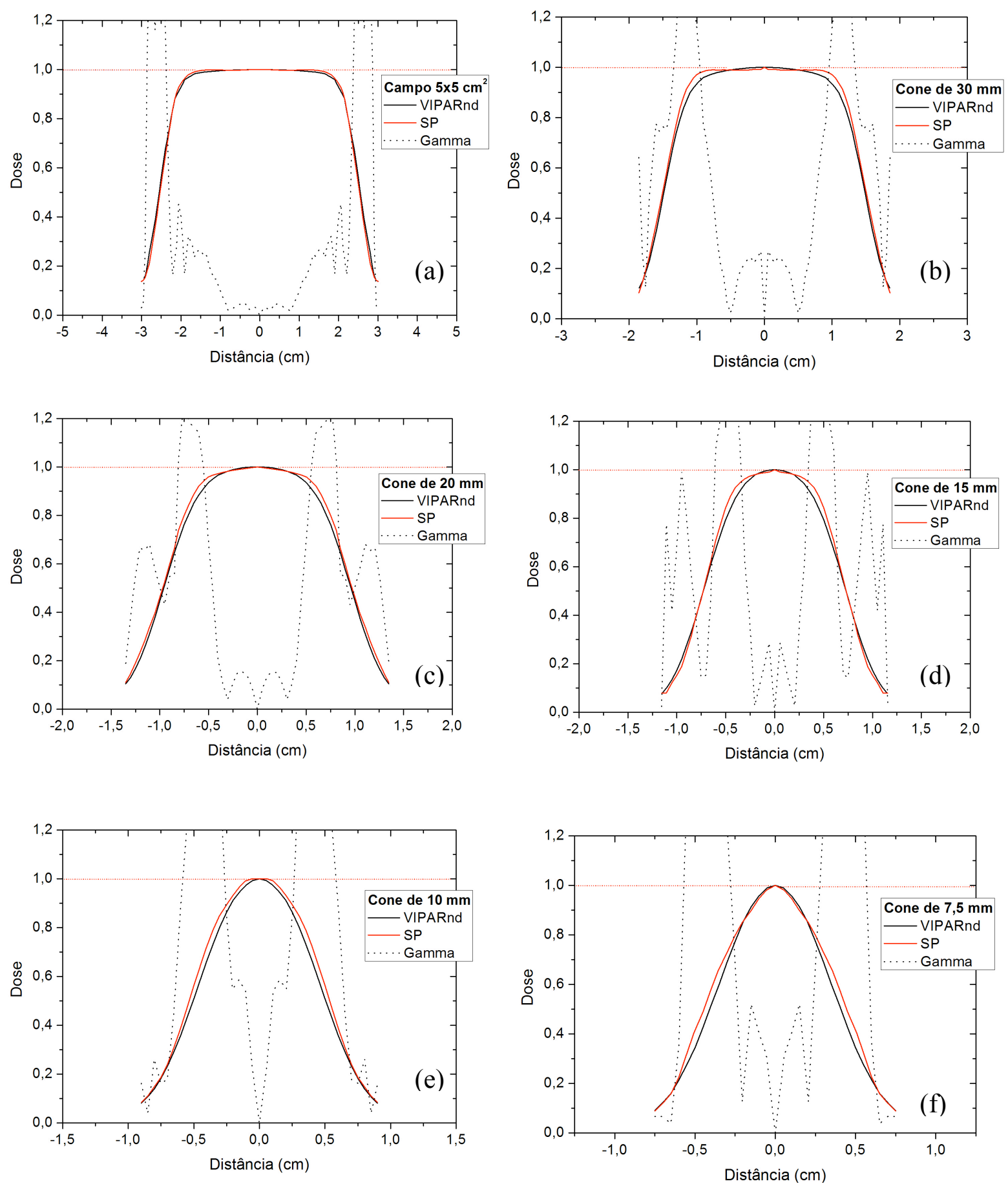

Figura 40 - Comparação entre as medidas de perfil obtidas com gel VIPARnd e os dados do sistema de planejamento (SP). (a) Campo $5 \mathrm{~cm}$ x $5 \mathrm{~cm}$, (b) cone de $30 \mathrm{~mm}$, (c) cone de $20 \mathrm{~mm}$, (d) cone de $15 \mathrm{~mm}$, (e) cone de $10 \mathrm{~mm}$, (f) cone de 7,5 mm.

Na tabela 5 são apresentados a porcentagem de pontos falhos ao critério de $3 \%$ em $3 \mathrm{~mm}$ usado para cálculo do índice Gamma. 
Tabela 5 - Porcentagem de pontos falhos na análise Gamma $3 \%, 3 \mathrm{~mm}$.

\begin{tabular}{|l|c|}
\cline { 2 - 2 } \multicolumn{1}{c|}{} & Pontos falhos na análise Gamma \\
\hline Campo $5 \mathrm{~cm} \times 5 \mathrm{~cm}$ & $16,5 \%$ \\
\hline Cone de $30 \mathrm{~mm}$ & $18,0 \%$ \\
\hline Cone de $20 \mathrm{~mm}$ & $21,8 \%$ \\
\hline Cone de $15 \mathrm{~mm}$ & $25,5 \%$ \\
\hline Cone de $10 \mathrm{~mm}$ & $32,4 \%$ \\
\hline Cone de $7,5 \mathrm{~mm}$ & $38,7 \%$ \\
\hline
\end{tabular}

A partir dos dados mostrados na Tabela 5 podemos observar que à medida que o tamanho do campo diminui, menor a concordância entre as medidas realizadas com VIPARnd e os dados do sistema de planejamento. De fato as medidas de campos pequenos em radioterapia são críticas para a maior parte dos detectores. Com base nos resultados obtidos, sugere-se a utilização de uma metodologia com maior resolução espacial em dose.

\subsection{Medidas de PDP}

Na Figura 41 podemos visualizar uma imagem do tubo de ensaio usado para medidas de PDP após a irradiação.

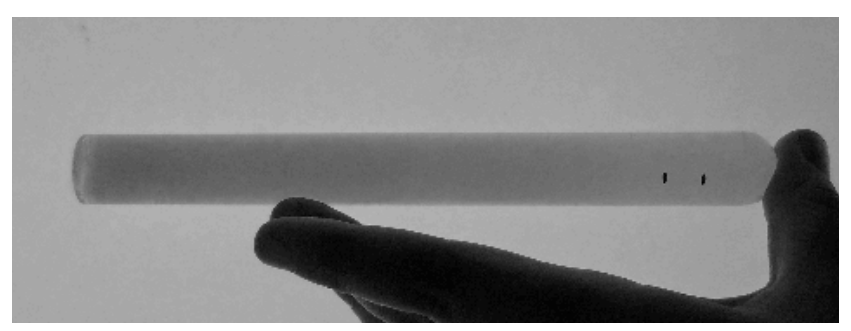

Figura 41 - Tubo de ensaio usado para medida de PDP após a irradiação.

A Figura 42 apresenta as medidas obtidas através da análise das imagens com VIPARnd e os dados do sistema de planejamento para a PDP de um campo $10 \mathrm{~cm} \times 10 \mathrm{~cm}$. 


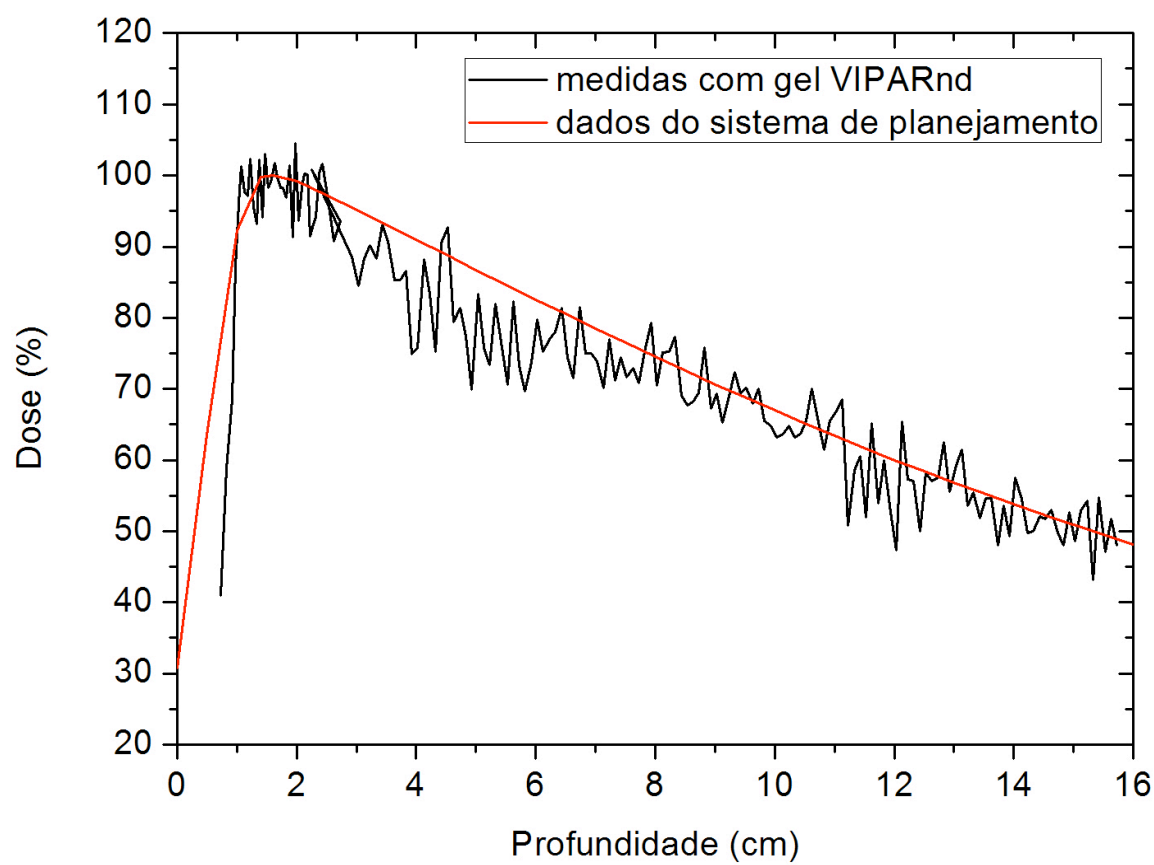

Figura 42 - Comparação entre a medida de PDP para um campo de $10 \mathrm{~cm}$ x $10 \mathrm{~cm}$ obtida com gel VIPARnd e os dados do sistema de planejamento.

Conforme visualizado na Figura 42 as medidas realizadas com VIPARnd apresentam mesma tendência que a curva de PDP extraída do sistema de planejamento. Como os pontos iniciais da curva de PDP apresentam grande variação na dose, optou-se por não suavizar o sinal obtido, que é bastante ruidoso. Não foi possível também extrair os pontos de dose para as profundidades próximas à superfície, por degradação do gel nesta região. Vale ressaltar que o tubo de ensaio utilizado não respeita os critérios de caminho óptico necessários para aplicação do conceito de densidade óptica, devido a espessura do vidro e da espessura da parte interna do tubo. Assim a medida apresentada é apenas um resultado preliminar.

\subsection{Medidas com fonte de Braquiterapia}

A imagem do frasco de vidro adquirida para a análise de dose com a fonte de irídio 192 para braquiterapia de alta taxa de dose é apresentada na Figura 43. 


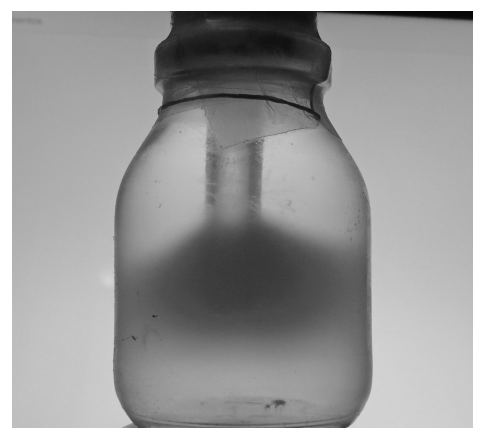

Figura 43 - Imagem do frasco de vidro após irradiação com fonte de irídio 192.

Na Figura 44 são apresentadas as medidas obtidas através da análise da imagem e a distribuição de dose prevista pelo sistema de planejamento.

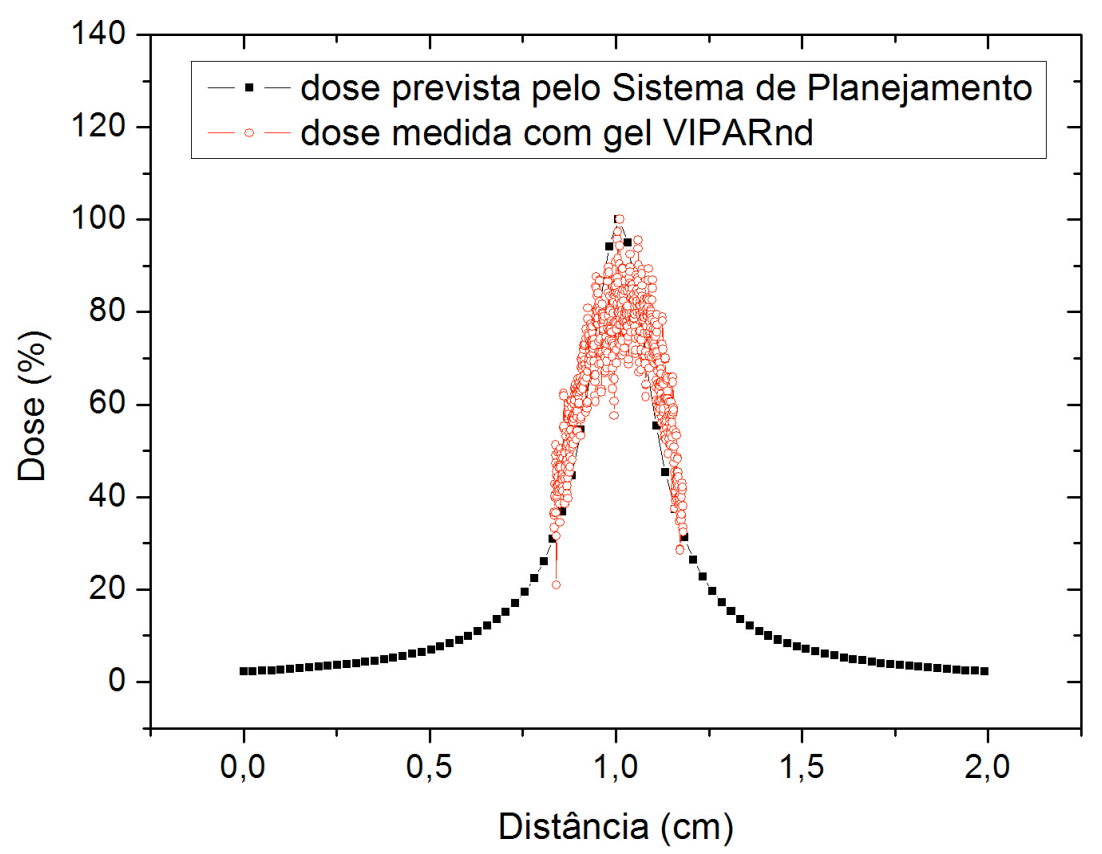

Figura 44 - Comparação entre a distribuição de dose medida com VIPARnd para o plano de braquiterapia e a distribuição prevista pelo sistema de planejamento.

De acordo com os dados mostrados na Figura 44 podemos observar que a região central de dose prevista com o gel VIPARnd apresenta concordância com a distribuição prevista pelo sistema de planejamento. As doses periféricas foram descartadas devido ao borramento da imagem nesta região. De fato sabe-se que o frasco utilizado possui parede e espessura interna bastante extensa para a análise óptica realizada, assim o borramento nas bordas do frasco podem ser decorrentes de sobreposição de dose em profundidade, uma vez que a distribuição de dose é tridimensional. 


\subsection{Medidas com Tomografia Computadorizada}

Na Figura 45 é apresentado um corte axial da tomografia computadorizada adquirida para um lote de cubetas.

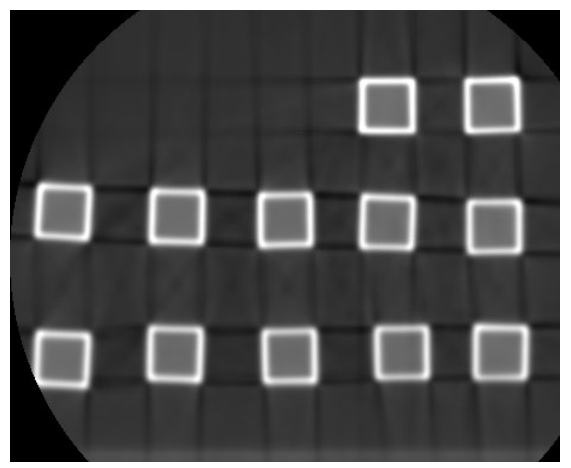

Figura 45 - Imagem axial obtida a partir da tomografia computadorizada de um lote de cubetas.

A curva dose resposta obtida em função do número TC é apresentada na Figura 46. Foi inserido uma linha pontilhada para ressaltar o aumento do número TC com a dose.

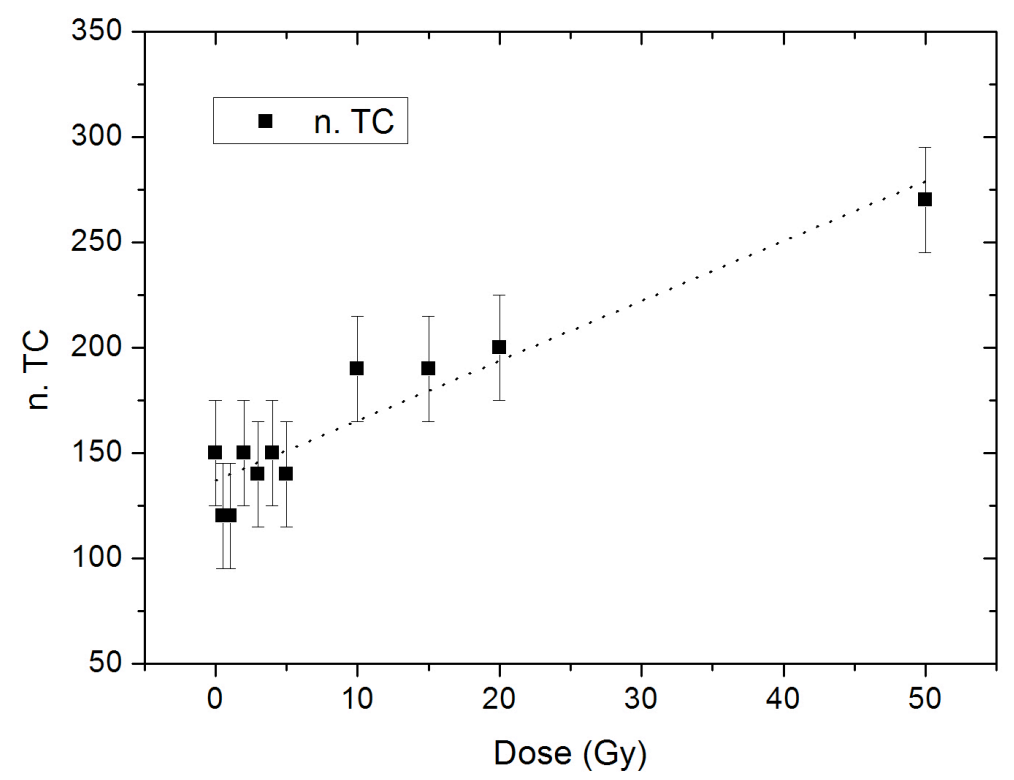

Figura 46 - Curva dose resposta em função do número TC para a solução 2 de VIPARnd. 
Pode ser visualizado através dos dados apresentados na Figura 46, que o aumento de dose proporciona um aumento no número TC do gel. No entanto é possível observar que a sensibilidade para dose baixas é reduzida, não se consegue diferenciar os valores para doses menores que $20 \mathrm{~Gy}$. 


\section{Capítulo 5 Conclusões}




\section{CONCLUSÕES}

O espectro de absorção do dosímetro gel VIPARnd irradiado com feixes clínicos de raios X de $6 \mathrm{MV}$ apresentou banda de absorvância entre 300 e $320 \mathrm{~nm}$. O valor máximo de absorvância é proporcional à dose a qual o dosímetro é exposto, característica da opacidade causada pela interação do gel com a radiação ionizante.

O estudo da metodologia para a confecção do dosímetro gel do tipo VIPARnd foi fundamental para identificar os fatores relevantes para que o gel apresente boa repetitividade e reprodutibilidade, características importantes para a padronização de sua confecção. Foi constatado que o cuidado em evitar bolhas nos recipientes de acondicionamento do gel é de extrema importância, pois a presença de oxigênio pode atrapalhar o processo de polimerização. A necessidade de manter a refrigeração também é crucial, um item obedecido em toda as etapas experimentais. Controlando estas condições a repetitividade do gel VIPARnd para as amostras analisadas ficou em $\pm 0,5 \%$ e a reprodutibilidade encontrada para amostras inter-lotes foi de $\pm 5 \%$.

A região linear para a curva de dose resposta em função dos valores máximos de absorvância para a solução 1 ficou entre 3 e 20 Gy e para a solução 2 no intervalo de 0,5 a 5 Gy. Os intervalos lineares para a curva de dose resposta em função da área sob as curvas de absorção da solução 1 se mantiveram inalterados, assim para esta solução não há justificativa para essa análise, afinal a leitura a partir do máximo de absorção é mais prática e rápida. Para a solução 2 foi possível observar um aumento discreto no limite superior do intervalo de dose, tanto que o ajuste linear foi realizado para o intervalo de 0,5 a 10 Gy. Assim a análise da área sob a curva de absorção pode ser útil para extensão da faixa útil do gel preparado a partir da solução 2 .

As variações no intervalo de resposta para as duas soluções estudadas são decorrentes das diferentes concentrações utilizadas de NVP e BIS, componentes principais do processo de polimerização. Fica claro que com uma quantidade maior destes componentes na solução, maior a sensibilização para doses mais baixas, em contrapartida a saturação para leituras baseadas em análises ópticas também ocorrerá para um valor menor de dose. Com base nessas informações é possível ajustar o intervalo de resposta do gel VIPARnd modificando as concentrações dos componentes usados em sua confecção. Para a concentração usada na solução 1 a análise por espectrofotometria óptica na região visível e ultra-violeta apresenta limitações para 
detecção de doses acima de 20 Gy e para a solução 2 para doses acima de 5 Gy. Nestes valores de dose, o gel fica bastante opaco (esbranquiçado) fazendo com que a absorvância do material assuma valores bastante altos, a saturação então ocorre por uma limitação na detecção com a instrumentação utilizada.

Através das análises feitas para diferentes tempos de leitura após a irradiação do gel, pode-se afirmar que o gel permanece estável para um intervalo de até $360 \mathrm{~h}$ (15 dias) após a irradiação das amostras. Vale lembrar que as condições de armazenamento e refrigeração precisam sempre ser mantidas.

Para as análises realizadas através do sistema de leitura com câmera de sensor CMOS, foi possível observar que para uma imagem RGB a componente com maior resposta em dose foi a azul. Este componente é a cor mais próxima do valor de máxima absorção no espectro do VIPARnd. A componente verde também apresenta boa resposta para as soluções estudadas. Em contrapartida a componente com menos informação é a vermelha, o que sugere sua não utilização para este sistema de leitura. A metodologia com a utilização da componente azul e verde apresentou resposta linear de 3 a 20 Gy para a solução 1, intervalo semelhante ao encontrado através das análises com espectrofotometria óptica. Para a solução 2 o intervalo linear foi aumentado, ficando de 0,5 a 20 Gy. Estes resultados favorecem a aplicação dessa metodologia, em virtude dos resultados, além da facilidade e a velocidade de obtenção dos valores do sinal.

Para a validação da metodologia para medidas de perfil de campos pequenos e de PDP é necessário melhorar a resolução espacial em dose do gel e realizar comparação de medidas feitas com outros detectores ou comparar com os dados previstos por simulação computacional.

As medidas em braquiterapia de alta taxa de dose mostraram que o gel VIPARnd também é sensível à radiação produzida por fontes de irídio 192.

A análise de resposta do gel através das medidas com tomografia computadorizada sugerem sensibilidade apenas para doses altas acima de 20 Gy.

Assim com os resultados obtidos pode-se afirmar que as leituras através de análises ópticas para o gel VIPARnd são utéis para a dosimetria de feixes de raios X de $6 \mathrm{MV}$. Esta análise inicial é importante para o desenvolvimento de outras metodologias de análise da distribuição de dose nas verificações necessárias no uso clínico deste feixe de radiação. 
As sugestões para trabalhos futuros são: o aperfeiçoamento da metodologia de aquisição de dados com imagens de câmera de sensor CMOS; o estudo de alterações na composição do gel que melhorem a sensibilidade para investigações ópticas, tais como inserção de corantes ou uso de novos materiais na solução; investigação das propriedades elétricas do material, verificando se há alterações nas mesmas devido à polimerização causada pela radiação ionizante; e implementação de técnicas de leituras que permitam a avalição tridimensional das distribuições de dose. 


\section{REFERÊNCIAS BIBLIOGRÁFICAS}

[1] Khan F M. Treatment Planning in Radiation Oncology. Philadelphia: Editora Lippincott Williams ad Wilkins, 2a . Ed., 2007.

[2] Hall E J. Radiobioly for the Radiologist. Philadelphia: Editora Lippincott Williams ad Wilkins, 5a. Ed., 2000.

[3] Khan F M. The physics of radiation therapy. Baltimore: Editora Lippincott Williams ad Wilkins, $3^{\text {a }}$. Ed., 2003.

[4] Programa de Qualidade em Radioterapia (PQRT), Instituto Nacional do Câncer (INCA), Ministério da Saúde (MS). TEC DOC - 1151: Aspectos físicos da garantia da qualidade em radioterapia, Rio de Janeiro, 2000.

[5] Scaff, L. Física na radioterapia - a base analógica de uma era digital. São Paulo: Editora Projeto Saber, 1ª Ed., 2010.

[6] International Commission on Radiation Units and Measurements (ICRU). Report 24: Determination of absorbed dose in a Patient Irradiated by Beams of X or Gamma Rays in Radiotherapy Procedures, 1976.

[7] Low D A, Harms W B, Mutic S. A technique for the quantitative evaluation of dose distributions. Med. Phys. 1998; 25(5): 656-661.

[8] Knoll G F. Radiation Detection and Measurement. Hoboken: Editora John Wiley and Sons, 2a . Ed., 2010.

[9] Baldock C, De Deene Y, Doran S, Ibbott G, Jirasek A, Lepage M, et al. Polymer gel dosimetry. Phys. Med. Biol. 2010; 55:R1-R63.

[10] Un A. Water and tissue equivalency of some gel dosimeters for photon energy absorption. Appl. Radiat. and Isotopes 2013; 82:258-263. 
[11] Maryanski M J, Ibbott G S, Eastman P, Schulz R J, Gore J C. Radiation therapy dosimetry using magnetic resonance imaging of polymer gels. Med. Phys. 1996; 23:699-705.

[12] Gore J C, Kang Y S, Schulz R J. Measurement of radiation dose distributions by nuclear magnetic resonance (NMR) imaging. Phys. Med. Biol. 1984; 29(10):1189-1197.

[13] Maryanski M J, Gore J C, Kennan R P, Schulz R J. NMR relaxation enhancement in gels polymerized and cross-linked by ionizing radiation: a new approach to 3D dosimetry by MRI. Magn. Reson. Imaging 1993; 11: 253-25.

[14] Fong P M, Keil D C, Does M D, Gore J C. Polymer gels for magnetic resonance imaging of radiation dose distributions at normal room atmosphere. Phys. Med. Biol. 2001; 46:3105-3113.

[15] Pappas E, Maris T, Angelopoulos A, Paparigopoulou M, Sakelliou L, Sandilos $\mathrm{P}$, et al. A new polymer gel for magnetic resonance imaging (MRI) radiation dosimetry. Phys. Med. Biol. 1999; 44:2677-2684.

[16] Kozicki M, Maras P, Rybka K, Biegański T, Kadłubowski S, Petrokokkinos L. On the development of the VIPAR polymer gel dosimeter for threedimensional dose measurements. Macromol. Symp. 2007; 254:345-352.

[17] Podgorsak E B. Radiation Oncology Physics: A Handbook for Teachers and Students. Vienna: Atomic Energy Agency, 2005.

[18] Johns H E, Cunningham J R. The physics of radiology. Springfield: Charles C Thomas, $4^{\text {a }}$. Ed., 1986.

[19] Eisberg R, Resnick R. Física Quântica. São Paulo: Editora Campus, 9ª.Ed., 1994.

[20] Tauhata L, Salati I P, Di Prinzio R, Di Prinzio A R. Radioproteção e Dosimetria: Fundamentos. Rio de Janeiro: IRD/CNEN, $6^{\mathrm{a}}$. rev., 2006. 
[21] Attix F H. Introduction to radiological physics and radiation dosimetry. London: John Willey \& Sons, 1986.

[22] International Atomic Energy Agency. Technical Reports Series (TRS) no 398 : Absorbed dose determination in external beam radiotherapy: an international code of practice for dosimetry based on standards of absorbed dose to water, Vienna, 2004.

[23] Ju S G, Ahn Y C, Huh S J, Yeo I J. Film dosimetry for intensity-modulated radiation therapy: dosimetric evaluation. Med. Phys. 2002; 20: 351-355.

[24] Poppea B, Blechschmidt A, Djouguela A, Kollhoff R, Rubach A, Willborn K C, Harder D. Two-dimensional ionization chamber arrays for IMRT plan verification. Med. Phys. 2006; 33(4): 1005-1014.

[25] Macdougall N D, Pitchfrod W G, Smith M A. A systematic review of the precision and accuracy of dose measurements in photon radiotherapy using polymer and Fricke MRI gel dosimetry. Phys. Med. and Biol. 2002; 47:107-121.

[26] Schreiner L J. Review of Fricke gel dosimeters. Journal of Physics 2004; 3:9-21.

[27] De Deene Y, Hurley C, Venning A, Vergote K, Mather M, Helay B J, Baldock C. A basic study of some normoxic polymer gel dosimeters. Phys. Med. Biol. 2002; 47:3441-3463.

[28] McJury M, Oldham M, Cosgrove V P, Murphy P S, Doran S, Leach M O, Webb S. Radiotherapy dosimetry using polymer gels: methods and applications. Brit. J. Rad. 2000, 73: 919-929.

[29] De Deene Y, Hanselaer P, De Wagter C, Achten E, De Neve W. An investigation of the chemical stability of a monomer/polymer gel dosimeter. Phys. Med. Biol. 2000; 45:859-878. 
[30] Baldock C, Greener A G, Billingham N C, Burford R, Keevil S F. Energy response and tissue equivalence of polymer gels for radiation dosimetry by MRI. Proc. Eur. Soc. Magn. Resonance Med. Biol. 1996; 2:312.

[31] Gustavsson H, Karlsson A, Back S A J, Olsson L E. MAGIC-type polymer gel for three-dimensional dosimetry: Intensity-modulated radiation therapy verification. Med. Phys. 2003; 30(6):1264-1271.

[32] Vergote K, De Deene Y, Claus F, De Gersem W, Van Duyse B, Paelinck L, et al. Application of monomer/polymer gel dosimetry to study the effects of tissue inhomogeneities on intensity-modulated radiation therapy (IMRT) dose distributions. Radiother. Oncol. 2003; 67:119-128.

[33] Vergote K, De Deene Y, Duthoy W, De Gersem W, De Neve W, Achten E. Validation and application of polymer gel dosimetry for the dose verification of an intensity-modulated arc therapy (IMAT) treatment. Phys. Med. Biol. 2004; 49:287-305.

[34] Ceberg S, Gagne I, Gustafsson H, Scherman J B, Korreman S S, KjaerKristoffersen F, et al. RapidArc treatment verification in 3D using polymer gel dosimetry and Monte Carlo simulation. Phys. Med. Biol. 2010; 55:4885-4898.

[35] Papagiannis P, Karaiskos P, Kozicki M, Rosiak J M, Sakelliou L, Sandilos P, et al. Three-dimensional dose verification of the clinical application of gamma knife stereotactic radiosurgery using polymer gel and MRI. Phys. Med. Biol. 2005; 50:1979-1990.

[36] Gopishankar N, Watanabe Y, Subbiah V. MRI-based polymer gel dosimetry for validating plans with multiple matrices in Gamma Knife stereotactic radiosurgery. J. Appl. Clin. Med. Phys. 2011; 12:133-145.

[37] Baras P, Seimenis I., Kipouros P, Papagiannis P, Angelopoulos A, Sakelliou L, et al. Polymer gel dosimetry using a three-dimensional MRI acquisition technique, Med. Phys. 2002; 29 (11):2506-2516. 
[38] Zeidan O A, Sriprisan S I, Lopatiuk-Tirpak O, Kupelian P A, Meeks S L, Hsi W C Z, et al. Dosimetric evaluation of a novel polymer gel dosimeter for proton therapy, Med. Phys. 2010; 37(5):2145-2152.

[39] Mangueira T F, Silva C F, Coelho P R P, Campos L L. Gamma/neutron dose evaluation using Fricke gel and alanine gel dosimeters to be applied in boron neutron capture therapy. Appl. Radiat. and Isotopes 2010; 68:791-794.

[40] Gambarini G, Carrara M, Mariani M, Pirola L, Tomatis S, Valente M, et al. Optical analysis of gel dosimeters: Comparison of Fricke and normoxic polymer gels. Nucl. Instr. and Meth. B 2007; 263:191-195.

[41] Abtahi S M, Aghamiri S M R, Khalafi H, Optical and MRI investigations of an optimized acrylamide-based polymer gel dosimeter. J. Radioanal. Nucl. Chem. 2014; 300:287-301.

[42] Oldham M, Siewerdsen J H, Shetty A, Jaffray D A. High resolution geldosimetry by optical-CT and MR scanning. Med. Phys. 2001; 28:1436-1445.

[43] Kozicki M. How do monomeric componentes of a polymer gel dosimeter respond to ionising radiation: A steady-state radiolysis towards preparation of a 3D polymer gel dosimter. Rad. Phys. and Chem. 2011; 80:1419-1436.

[44] Hill B, Venning A J, Baldock C, Polymer gel dosimetry on a multislice computed tomography scanner: Effect of changing parameters on CTDI. Physica Medica 2008; 24:149-158.

[45] Mather M, Whittaker A K, Baldock C. Ultrasound evaluation of polymer gel dosimeters. Phys. Med. Biol. 2002; 47:1449-1458.

[46] De Deene Y, Baldock C. Optimization of multiple spin-echo sequences for 3D polymer gel dosimetry. Phys. Med. Biol. 2002; 47:3117-3141. 
[47] Trapp J V, Back S A J, Lepage M, Michael D, Baldock C. An experimental study of the dose reponse of polymer gel dosimeters imaged with x-ray computed tomography. Phys. Med. Biol. 2005; 50:1727-1745.

[48] Papadakis A E, Maris T G, Zacharopoulou F, Pappas E, Zacharakis G and Damilakis J. An evaluation of the dosimetric performance characteristics of nvinylpyrrolidone-based polymer gels Phys. Med. Biol. 2007; 52: 5069-83.

[49] Papoutsaki M-V, Pappas E, Papadakis A E, Varveris C, Damilakis J, Maris T G. Dosimetric characteristics of N-vinylpyrrolidone based polymer gels: utilization depending on dose range. Journal of Physics: Conference Series 2013; 444:012068.

[50] Papoutsaki M-V, Pappas E, Papadakis A E, Varveris C, Damilakis J, Maris T G. Dosimetric characteristics of a new polymer gel and their dependence on post-preparation and post-irradiation time: Effect on X-ray beam profile measurements. Physica Medica 2013; 29:453-460.

[51] McAuley K B. Fundamentals of Polymer Gel Dosimeters. Journal of Physics: Conference Series 2006, 56: 35-44.

[52] Kozicki M, Filipczak K, Rosiak J M. Reactions of hydroxyl radicals, H atoms and hydrated electrons with N-N'-methylenebisacrylamide in aqueous solution. A pulse radiolysis study. Radiation Phys. and Chem. 2003; 68:827-835.

[53] Davison A, Sangster D F, Lynn J E, Senogles. Pulse radiolysis of NVinylpyrrolidone. J. Polymer Scl. 1976, 55:249-257.

[54] Christ G. White polystyrene as a substitute for water in high energy photon dosimetry. Medical Physics 1995; 22:2097-2100.

[55] McLaughlin W L, Boyd A W, Chadwick K H, McDonald J C, Miller A. Dosimetry for radiation processing. London: Editora Taylor \& Francis, 1989. 